\title{
Effects of Managerial Overconfidence on the Relationship between Corporate Risk-Taking and Firm Value
}

\author{
Hyeon Sook Kim, Researcher, Public Procurement Service \\ Taek Ho Kwon ${ }^{* *}$, Professor, Chungnam National University
}

\begin{abstract}
$\langle$ Abstract $\rangle$
This study investigates two issues pertinent to managerial overconfidence (hereafter, MOC) and risk-taking from the perspective of behavioral corporate finance: (1) Does MOC influence the relationship between corporate risk-taking and firm value? (2) Can the effects of MOC be moderated through certain internal and external governance or personal factors? Using the KOSPI for non-financial firms from 2002 to 2015, this study examines the issues by identifying the firms with MOC from the measurement variables that are related to both the determinants and outcome of MOC. The main findings are as follows. First, firms with overconfident managers tend to experience lower firm value compared to those with nonoverconfident managers because of their inappropriate or excessive risk-taking behavior. This finding suggests that in addition to agency problems, MOC can have negative effects on the relationship between risk-taking and firm value in Korean firms. Second, there are no significant internal or external governance control effects, such as outside directors' control over obligations, a sound board of directors, the control of chaebols, a less-competitive indus-try, and less economic policy uncertainty over the negative effects of MOC, on the relation-ship between risk-taking and firm value. In contrast, the negative effects of MOC turn weak in terms of personal factors when the managers become older. These results show that con-trolling for the negative effects of MOC through internal or external governance mechanisms is not easy, even though these mechanisms may be helpful to control for the agency problem in Korean firms. Nevertheless, the results confirm that the effects of MOC depend on managers' personal traits. This study shows that managers should be wary of their own overconfidence and restrain themselves from making irrational decisions. Furthermore, this study suggests that the board of directors needs to react against MOC and improve the board's control over MOC in order to avoid its negative effects.
\end{abstract}

Keywords: Managerial Overconfidence; Risk-Taking; Firm Value; Corporate Governance; Manager's Age

JEL Classification: D91, G32, G41, M12

\footnotetext{
* We are grateful to participants of 2018 Joint Conference of Five Academic Institutes for Finance and two anonymous referees for their constructive comments. This study is in part based on Kim's Ph. D. dissertation.

** Corresponding Author. Address: Chungnam National University, 99 Daehak-ro, Yuseong-gu, Daejeon, Korea 34134; E-mail: thk5556@cnu.ac.kr; Tel: +82-42-821-5533; Fax: +82-42-821-8718.
}

Received: September 27, 2018; Revised: February 15, 2019 \& May 14, 2019; Accepted: May 20, 2019 


\title{
경영자 과신이 위험추구와 기업가치의 관계에 미치는 영향"
}

\author{
김 현 숙 (조달청 연구원) \\ 권 택 호 (충남대학교 교수)**
}

과신 성향의 경영자는 본래보다 위험을 과소평가하거나 이익을 과대평가해 위험추구와 관련된 다양한 의사결정을 함으로써 궁극적으로 기업가치에 영향을 미칠 수 있다. 이러한 관점을 토대로 본 연구는 국내 기업의 위험추구와 기업가치의 관계에서 경영자 과신의 효과를 분석하고, 이후 지배구조 및 경영자의 인적 특성 관점에서 과신의 효과에 대한 조절 요인을 총체적으로 검증한다. 2002년부터 2015년까지 유가증권시장 상장기업을 대상으로 경영자 과신의 원인 및 결과로 측정되는 변수들을 조합해 경영자 과신 기업을 식별한 뒤, 경영자 과신의 효과를 검증하였다. 분석결과 기업의 위험추구는 기업가치를 증가시키지만, 경영자가 과신하는 경우 해당 기업의 위험추구는 기업가치 하락과 연관이 있었다. 이는 과신 성향의 경영자가 해당 기업에 부적합하거나 과도한 위험추구를 유도함으로써 결국 기업가치를 훼손시킬 수 있다는 것을 보여주는 결과이다. 한편 기업 내·외부 지배구조 관점에서 사외이사 초과 선임, 양호한 이사회 역할, 재벌집단 소속, 경제정책 불확실 완화, 산업 내 경쟁 축소로부터 과신의 부정적 효과가 완화된다는 증거는 찾기 어려웠다. 반면 경영자의 평균 나이가 많은 경우 과신에 따른 기업가치 하락이 완화되어, 과거 국내 기업의 경우 경영자 과신의 부정적 효과가 특정한 기업지배구조 수단에 의해 통제되기보다는 그러한 심리적 오류를 갖고 있는 경영자의 인적 특성에 보다 의존함을 확인하였다. 본 연구의 실증결과는 국내 경영자의 대리인 문제 이외에도 그들의 과신 오류가 위험추구와 기업가치의 관계에 부정적일 수 있음을 실증적으로 보여주었다는데 의의가 있다. 추가로 본 연구는 과신의 부정적 효과를 완화하기 위해 지배구조의 통제에 선행하여 경영자 스스로가 과신 가능성을 경계하는 것이 무엇보다 중요하다는 점을 시사한다. 동시에 여타 지배구조 요인에 비해 경영자의 과신 행태와 직·간접적 연관성이 높은 이사회가 경영자의 의사결정 오류를 효율적으로 통제할 수 있도록 기업 내부적, 제도적 역할 보완이 보다 필요함을 시사한다.

핵심 단어 : 경영자 과신, 위험추구, 기업가치, 지배구조, 경영자 나이

JEL 분류기호: D91, G32, G41, M12

* 본 논문을 위해 유익한 조언을 해 주신 2018 재무금융 관련 5 개 학회 학술연구발표회 참가자분들과 익명의 두 분 심사자께 깊은 감사의 뜻을 전합니다. 본 연구는 김현숙의 박사학위 논문을 기반으로 수정 보완되었습니다.

** 연락담당 저자. 주소: 대전광역시 유성구 대학로 99 충남대학교 경상대학 경영학부, 34134; E-mail: thk5556@cnu.ac.kr; Tel: 042-821-5533; Fax: 042-821-8718. 


\section{1. 서론}

최근까지의 연구에 의하면 경영자의 과신은 실재하며, 기업 활동에 유의적인 영향을 미친다는 결과가 상당하다. 관련 연구에서 경영자는 자신의 능력이나 판단 또는 결과의 성공에 대한 전망을 실제보다 과대평가할 수 있으며, 이러한 심리적 편의를 바탕으로 투자 및 재무활동 등 다양한 개별 기업의사결정에 영향을 미친다고 한다.

그러나 기업의 개별의사결정을 중심으로 경영자 과신의 효과를 검증하는 연구의 중요에도 불구하고, 그것의 총체적인 효과는 무엇인가에 대한 답은 여전히 혼재되어 있다. 경영자의 과신은 기업의 적극적인 위험추구를 유도함으로써 과소투자문제를 완화시키고, 기업의 성장기회를 고려해 혁신활동을 증가시키는 등 기업가치를 제고시킬 수 있다(Goel and Thakor, 2008; Hackbarth, 2009; Galasso and Simcoe, 2011; Gervais et al., 2011; Hirshleifer et al., 2012). 반면 경영자의 과신은 과도한 위험추구로 이어져 불리한 인수합병의 시도나 무리한 투자를 통해 투자정책을 왜곡시키고, 위험관리 실패를 야기하는 등 기업 활동에 비교적 부정적이라고 평가되기도 한다(Hayward and Hambrick, 1997; Malmendier and Tate, 2005, 2008; Campbell et al., 2011; Schrand and Zechman, 2012; Chen et al., 2014; Adam et al., 2015). 이렇듯 경영자 과신의 효과가 기업에 미치는 영향은 상반된 결과가 상존하므로, 여전히 이에 대한 추가적인 검토가 요구된다.

그렇다면 경영자 과신의 효과 검증은 어떠한 관점으로 분석되어야 할까? 본질적으로 과신 성향의 경영자는 위험을 과소평가하거나 이익을 과대평가함으로써 기업의 위험을 증가시킨다 (Goel and Thakor, 2008; Gervais et al., 2011; Hirshleifer et al., 2012; Baker and Wurgler, 2013). 그리고 경영자의 과신은 이러한 위험 추구 차원에서 투자활동, 자본조달, 위험관리 등 다양한 개별 의사결정에 영향을 주며 기업가치에도 영향을 미칠 수 있게 된다. 한편 기업의 경영활동에 내재된 현재의 위험 수준이 과소·최적·과대 상황인지에 따라 이러한 경영자 과신으로 인한 위험 수준의 변화가 기업가치에 미치는 효과는 상이한 방향으로 나타날 수 있다. 따라서 경영자 과신의 전체적인 효과는 위험추구 상황에서 확인되어야 하되, 단순히 위험추구 수준의 변화를 확인(Chen et al., 2014; Li and Tang, 2010)하는 것이 아닌 궁극적인 기업가치 차원에서 검증될 필요가 있다. 물론 경영자 과신과 기업가치의 관계를 직접 검증할 수도 있으나(Hirshleifer et al., 2012; Bharati et al., 2016; Park et al., 2013), 이러한 경우 경영자 과신이 어떠한 메커니즘에 의해 기업가치를 설명하는지 명확한 답을 얻지 못할 수 있다.

한편 경영자의 과신이 위험추구를 통해 궁극적인 기업가치에 영향을 미친다면, 이에 대한 조절 요인을 확인하는 것 역시 기업 및 투자자에게 중요할 것이다. 이와 관련해 기존 연구들은 주로 경영자를 통제하는 이사회, 조직구조 등 내부 지배구조 요인의 중요성을 강조하거나, 그 조절 효과를 실증 검증해왔다(Hayward and Hambrick, 1997; Heaton, 2002; Goel and Thakor, 2008; Malmendier and Tate, 2008; Campbell et al., 2011; Kolasinski and Li, 2013; Park et al., 2013). 보다 최근의 연구들은 시장 경쟁 환경이나 불확실성 등 기업 외부 지배구조 요인에 의해 경영자의 과신 행동이 영향을 받는다고 설명하기도 한다(Li and Tang, 2010; Tang et 
Effects of Managerial Overconfidence on the Relationship between Corporate Risk-Taking and Firm Value

al., 2016; Kang et al., 2017). 한편 경영자의 주관적 또는 재량적인 의사결정은 기업 내부 요인 및 외부 경영환경 뿐만 아니라, 그들의 과거의 경험이나 나이와 같은 개인적 특성에 의해서도 영향을 받는다(Hambrick and Finkelstein, 1987; Li and Tang, 2010; Malmendier et al., 2011; Tang et al., 2016). 때문에 경영자 과신의 효과를 조절하는 요인은 기업 내·외부 지배구조 요인뿐만 아니라 경영자의 인적 특성까지 포괄해 그 유효성이 검토될 필요가 있다.

다수의 해외 선행연구와 달리 국내 기업을 대상으로 경영자 과신의 효과나 조절 요인을 확인한 연구는 상대적으로 소수에 그친다. 더욱이 국내 연구의 경우 분석기간 및 경영자 과신의 측정 방법이 각기 상이하고 연구된 주제도 제한돼 일반적인 해석을 하기에 해외의 경우보다 더 큰 한계점을 갖고 있다.1) 이는 경영자 과신의 정확한 추정이 쉽지 않음에도 불구하고 해외 연구들이 스톡옵션 행사 자료 등을 기초로 경영자의 과신을 측정하고 다양한 관점에서 이를 연구해 온 것과 달리, 국내의 경우 스톡옵션의 부여조차도 빈번하지 않아 관련 연구가 활성화되지 못한데 일부 이유가 있을 것이다. 경영자의 능력과 역량의 중요성이 강조되면서 관련 주제가 학계 및 실무의 지속적인 주목을 받고 있는 상황에서, 국내 역시 경영자 과신의 역할과 조절 기제를 확인해보는 시도가 필요하다고 판단된다.

한편, 위험추구 행태와 관련된 연구 영역에서도 국내 과신 경영자의 영향을 실증 검증해 볼 필요가 있다. 국내의 경우 기업의 위험추구에 대한 연구는 주로 대리인 이론 관점에서 위험 추구의 변화나 그 효과가 논의되어 왔다(Kook and Kang, 2010; Kim and Hwang, 2016; Lee and Byun, 2016). 반면 경영자의 과신 역시 위험추구와 직접적인 연관이 있음에도 불구하고 이를 기업의 위험추구 차원에서 실증 분석한 연구는 찾아보기 어렵다.2) 더욱이 대리인 문제로 인한 위험추구가 기업가치에 부정적이라는 일관된 설명(Jensen, 1986; Shleifer and Vishny

1) 국내 기업을 대상으로 한 연구들을 살펴보면, Park et al.(2013)은 2004년부터 2005년 유가증권시장 상장기업 중 자산 순위 200개 기업을 대상으로 연구하였으며, Hayward and Hambrick(1997)의 연구를 참고로 '언론매체의 긍정적인 기사'를 이용해 '사전적'으로 경영자의 과신이 유도될 만한 기업을 선정하고 과신의 부정적 효과와 이사회 및 재벌의 통제기제를 확인하였다. $\operatorname{Kim}(2016)$ 의 경우 Schrand and Zechman(2012)이 제시한 방법을 준용해 과신 성향이 '사후적'으로 기업 전반의 의사결정에 영향을 미친다는 사실을 이용해 '투자 및 재무의사결정'으로부터 과신 기업을 추론한 뒤 2001년부터 2011년 기간 동안 국내 경영자의 과신이 기업의 주가급락의 원인이 되지는 않는다고 주장하였다. 한편 Ryu and $\mathrm{Kim}(2015)$ 는 $\mathrm{Kim}(2016)$ 와 연구기간을 보다 확장해 2001년부터 2012년까지 기간을 연구대상으로 하고 있지만, 기업의 '과대투자 여부'만을 기준으로 과신 기업을 분류하여 경영자의 과신이 덜 보수적인 재무보고를 유도한다고 설명한다. 이상의 국내 연구들만 보더라도 경영자 과신의 측정방법과 기간이 각기 상이하고, 과신으로 인한 효과가 부정적이거나 또는 유의하지 않는 등 혼재됨을 확인할 수 있다. 이외 회계학 분야에서 조세회피(Cha et al., 2016), 원가비대칭성(Kim and Ryu, 2014) 등의 연구도 연구기간이나 과신 측정방법 면에서 Ryu and $\operatorname{Kim}(2015)$ 또는 $\operatorname{Kim}(2016)$ 의 방법과 크게 다르지 않았다.

2) 대리인 이론 관점에서 경영자는 자신의 사익에 유리한 의사결정을 통해서 기업의 위험추구 수준을 왜곡시킨다(Jensen, 1986; Shleifer and Vishny 1989; John et al., 2008). 과신 문제를 포함한 행태적 관점의 경우 경영자는 자신의 의사결정이 기업에 유리할 것이라는 주관적인 신념을 토대로 기업의 위험추구 수준을 변화시킨다(Baker and Wurgler, 2013). 결국 두 가지 관점 모두 가정은 다르지만 경영자의 행동이 기업의 위험추구행태와 밀접히 연관됨을 설명한다. 
한국증권학회지 제 48 권 5 호 (2019)

1989; John et al., 2008)과 달리, 경영자 과신의 효과는 앞에서 설명한 바와 같이 그 방향성이 명백하지 않다. 따라서 국내 기업의 위험추구와 기업가치가 경영자의 고의적인 사익추구에서 비롯된 대리인 문제가 아닌, 과신과 같은 심리적 오류에 의해서도 영향을 받는지 논증하고, 이의 조절 요인을 검토하는 것은 학술적 및 실무적으로도 필요한 주제라 사료된다.

이상의 기존 연구의 한계점과 추가 연구의 필요성을 토대로, 본 연구는 2002년부터 2015년까지 국내 기업을 대상으로 위험추구와 기업가치의 관계에서 경영자 과신의 효과와 이에 대한 조절 기제를 통합적으로 고찰하였다. 먼저 연구개발투자와 주가수익률 변동성 자료를 이용해 기업의 위험추구 수준이 Tobin's Q로 측정된 기업가치에 미치는 효과에 있어, 경영자의 과신 여부에 따라 유의한 차이가 존재하는지 확인하였다. 이때 경영자의 과신 여부를 추정함에 있어 기존 이론 및 실증 연구를 토대로 과신의 원인과 결과를 설명할 수 있는 변수를 조합해 과신이 존재할 것으로 판단되는 기업을 식별했다. 구체적으로 경영자 과신을 형성하는 원인 가운데 하나인 최근의 높은 성과(Hayward and Hambrick, 1997)를 보인 기업을 대상으로, 과신으로 인해 나타날 수 있는 결과와 연관된 투자(Malmendier and Tate, 2005), 부채(Hackbath, 2008; Barros and Silverira, 2007), 경영자 이익 공시(Hribar and Yang, 2016) 자료를 활용해 최종 적으로 경영자가 과신했을 것으로 예상되는 표본을 추출해 연구에 활용했다.3)

주요 연구 결과 및 시사점은 다음과 같다. 첫째, 기업의 위험추구는 기업가치를 증가시키지만 경영자가 과신하는 경우 이러한 위험추구는 오히려 가치 하락과 연관이 있었다. 이는 본 연구의 차이분석 결과를 고려해 판단해볼 때, 경영자가 과신하는 기업은 현재의 기업 상황에 부적합하거나 과도한 위험추구를 선택할 수 있기 때문에 가치 하락을 경험한 것으로 해석된다. 둘째, 내부 지배구조 요인으로 사외이사 초과 선임 여부, 이사회 점수 상위 기업 여부, 재벌 소속 여부를 이용해 과신의 조절 효과를 분석한 결과, 해당 요인들은 경영자 과신의 부정적인 효과를 통제하지 못하는 것으로 나타났다. 이는 과거 국내의 경우 사외이사를 추가 선임하거나, 이사회 구성과 운영이 상대적으로 우수한 기업일지라도 이러한 이사회 구조가 경영자 과신에 의한 의사결정을 견제하는데 실효성이 높지 않았다는 것을 의미한다. 따라서 Hayward and Hambrick(1997), Park et al.(2013) 등의 관점과 차이를 보인다. 더불어 이러한 결과는 국내 이사회의 역할이 양호한 경우 대리인 문제 관점에서 경영자의 기회주의는 적절히 통제될 수 있지만(Park and Yon, 2009; Cho et al., 2016), 과신 관점에서 경영자의 비합리적 의사결정은 통제되기에 한계가 있음을 보여준다. 본 연구의 결과는 국내 재벌 집단의 계열 기업 관리가 소속 기업 경영자의 과신을 통제할 수 있다는 Park et al.(2013)의 주장과도 상충된다. 이는 재벌의 상호지원 및 위험공유 기회(Bae and Lim, 2003)가 오히려 과신 성향의 경영자로 하여금 기업이 처한 위험을 보다 과소평가하도록 유도해, 결국 재벌 본부의 통제라는 긍정적 효과를 상쇄시킨 것으로 이해할 수 있다. 셋째, 외부 지배구조 요인 관점에서 경제정책 불확실 및 시장 경쟁의 완화 역시 경영자 과신에 따른 부정적 효과를 통제하지 못했다. 이는 시장 불확실성과 경쟁 완화가 경영자의 재량적 판단을 줄이고 합리적 판단을 유도해 경영자의 과신 성향을 약화시킬 수도 있지만 $(\mathrm{Li}$

3) 본 연구는 과신 결과변수가 갖고 있는 다른 기업특성(예로, 대리인 문제, 파산위험)을 추가로 배제하고 있다. 해당 내용은 '3. 연구방법'에 자세히 기술하였다. 
Effects of Managerial Overconfidence on the Relationship between Corporate Risk-Taking and Firm Value

and Tang, 2010; Tang et al., 2016), 동시에 그들로 하여금 우호적인 시장 환경이라는 믿음을 갖게 하고 투자위험과 파산확률에 대한 심리적 부담을 낮춰 그들의 과신 성향을 강화시켰기 때문으로 판단된다. 넷째, 경영진의 평균 나이가 많은 경우 경영자 과신에 따른 기업가치 하락은 일부 완화되는 것으로 나타났다. 이는 경영자의 나이가 많을수록 상당한 직무 도전에 처할 가능성이 낮아지고 의사결정에 있어 심리적 편의에 영향을 덜 받기 때문에(Tang et al., 2016), 결국 경영자의 과신 가능성이 감소할 뿐만 아니라 과신의 부정적 효과가 완화된 것으로 해석할 수 있다.

이상으로부터 국내 과신 성향의 경영자는 위험추구와 관련된 의사결정 과정에서 기업가치를 훼손시킬 수 있으며, 이러한 경영자 과신의 부정적 효과를 통제하기 위해 기존 연구에서 주로 거론했던 기업지배구조 수단의 유효성에는 한계가 있음을 확인하였다. 오히려 과거 국내 경영자의 과신은 특정 수단에 의해 통제되기보다 그러한 심리적 오류의 주체인 경영자의 개인 특성에 보다 의존함을 확인하였다. 따라서 경영자 과신으로 인한 기업가치 하락을 완화하기 위해 경영자 스스로가 자기 과신 가능성을 경계해야 할 필요성이 무엇보다 중요하다는 점을 알 수 있었다. 추가로 본 연구의 결과는 과거 국내 이사회의 과신 통제 역할을 확인하지는 못하고 있다. 그럼에도 불구하고 이사회가 여타 지배구조 요인에 비해 주요 경영의사결정과 경영자 견제 역할에 핵심 위치에 있고, 경영자의 파워 수준이나 선·해임 결정을 통해 과신 성향 경영자의 존재와 무관하지 않다는 점(Goel and Thakor, 2008; Hwang et al., 2018)을 토대로 이사회의 내부적 노력과 제도적 역할 보완이 필요함을 시사한다.

본 연구의 의의는 다음과 같다. 첫째, 본 연구는 경영자 과신이 기업가치에 부정적일 수 있는 메커니즘을 확인하고, 과신의 유효한 조절 요인을 포괄적으로 검토한다는 점에서 경영자 과신 및 행태기업재무 분야의 연구에 기여하고 있다. 둘째, 본 연구는 국내 기업의 위험추구에 관한 연구의 범주를 대리인 문제 관점에서 벗어나 경영자 과신의 문제로 확대해 기존 연구를 보완한다. 특히 경영자 과신 역시 대리인 문제와 마찬가지로 국내 기업의 위험추구 과정에서 기업가치에 부정적인 영향을 초래하는 요인임을 보고한다. 또한 기업지배구조 강화로 인해 대리인 문제를 완화할지라도 경영자 과신에 의해 기업의 위험추구 전략이 왜곡될 여지가 있음을 설명한다. 셋째, 본 연구는 갈수록 기업지배구조 개선이 이루어지고 경영자의 경영 능력에 대한 중요성이 높아지는 한국 상황에서 시의적절한 연구가 될 것으로 판단된다. 해외와 달리 국내 경영자 과신을 다룬 연구는 학문 분야를 막론하고 비교적 초기 단계이며 분석기간, 대상, 주제가 매우 제한적이다. 본 연구는 장기간을 대상으로 과신의 효과 및 이의 조절 요인을 검토함으로써 기업 실무 및 제도적 시사점을 제시하고 있다. 마지막으로, 본 연구는 방법론 측면에서 선행연구들의 경영자 과신 측정 방법을 상당 부분 보완하고 있다. 특히 경영자 과신 원인과 결과 변수의 조합 및 과신 이외의 기업특성 요인을 배제해 과신 기업이 잘못 식별되거나 과대추정 될 수 있는 문제를 완화시키고 있다.

본 논문의 나머지 구성은 다음과 같다. 제 2장에서는 선행연구를 토대로 검증가설을 도출한다. 제 3장에서는 주요 변수의 측정, 연구 모형, 표본에 대해 설명한다. 제 4장에서는 실증분석결과를 보고하며, 제 5 장은 결론과 시사점을 제시한다. 


\section{2. 선행연구 및 검증가설}

과신하는 사람은 자신의 능력을 과대평가해 결과에 대해 예측 오류(miscalib- ration)를 범하거나, 그러한 결과가 평균보다 좋을 것이라 믿으며(better than average effect), 위험이 자신의 통제 가능한 수준 내에 있다고 인식하는 통제의 환상(illusion of control) 오류에 빠지기 쉽다. 특히 과신은 경영자에게서 비교적 흔히 나타난다고 알려져 있는데,4) 결국 이러한 심리적 편의로 인해 과신하는 경영자는 본래보다 위험을 과소평가하고 위험추구와 관련된 다양한 의사결정을 하게 된다(Ben-David et al., 2013). 따라서 경영자의 과신은 기업의 위험추구행태에 영향을 미치며, 궁극적으로 기업가치 변화에도 연관될 수 있다.

기업의 위험추구와 기업가치의 관계에서 경영자의 과신은 가치를 증가 또는 하락시키는 역할이 모두 가능하다. 먼저 이론적으로 경영자의 과신은 조직 내 지위 경쟁, 자본구조결정, 경영자 보상 등과 관련해 적극적인 위험추구를 통해 과소투자문제를 완화시키고 기업가치를 제고시킬 수 있다(Goel and Thakor, 2008; Hackbarth, 2009; Gervais et al., 2011). 관련해 Goel and Thakor(2008)는 기업의 내부 지배구조가 양호한 경우 과신하는 경영자가 보다 높은 조직 내 지위를 얻게 되는 이유를 과소투자문제 완화와 관련이 있다고 설명하였다. 즉, 조직 내 지위 경쟁과정에서 과신하는 경영자가 합리적인 의사결정을 하는 경영자에 비해 적극적인 위험추구를 통해 과소투자 문제를 완화시킬 수 있고, 결과적으로 이사회는 이러한 과신 성향의 경영자를 최고경영자로 선임한다는 것이다. Hackbarth(2009)의 경우 과신 및 낙관 등 심리적으로 편향된 경영자가 그렇지 않은 경영자에 비해 더 높은 부채 수준을 선택함에도 불구하고 투자를 조기에 실행하므로, 역시 과소투자문제를 완화시키고 주주-채권자간의 대리인 비용을 줄여 기업가치를 제고시킨다고 보았다. Gervais et al.(2011)은 위험회피적인 경영자의 적정 수준의 과신은 그로 하여금 덜 보수적인 의사결정을 하게 하므로, 경영자의 보상 수준에 영향을 미칠 뿐만 아니라 경영자로 하여금 자신의 보상 스케줄을 고려해 위험을 추구하고, 주주를 위해 헌신하도록 유도한다고 한다. 이러한 이론적 설명들과 유사한 맥락에서 Galasso and Simcoe(2011), Hirshleifer et al.(2012)는 실증분석을 통해 경영자의 과신이 기업의 적극적인 위험추구를 가능하게 하는데, 특히 기업의 성장기회를 고려해 R\&D 투자나 특허 인용과 같은 혁신활동을 증가시키고 기업가치 제고에 도움이 된다고 제시하였다.

반면 경영자의 과신으로 인해 기업이 적정 위험추구 수준을 보유하지 못하는 경우 기업가치는 감소할 수 있다. 앞서 언급한 Goel and Thakor(2008), Gervais et al. (2011)의 연구들은 경영자의 과신으로 인한 편익에도 불구하고, 과신 수준이 지나칠 경우 과대투자 문제가 유발되어 기업가치는

4) 개인의 과신 특성이 경영자에게 다소 빈번하게 나타나는 대표적인 이유는 다음과 같다. 먼저, 경영자의 의사결정 자체가 주관적인 사고에 의존해 결정되기 쉬운 매우 복잡한 상황에서 이루어기 때문에 경영자는 과신을 바탕으로 의사결정을 하기 쉽다(Baker and Wurgler, 2013). 또한 경영자는 조직의 훌륭한 성과, 높은 지위, 보상 등 자신감을 높이는 다양한 원인들을 통해 사후적으로 과신에 노출되기 쉽다(Hayward and Hambrick, 1997). 특히 최고경영자와 같이 높은 위치에 오른 경영자는 조직 내 지위 경쟁 과정에서 적극적인 위험추구를 통해 이사회로부터 최종 선택된 과신 성향을 갖는 경영자일 가능성도 있다(Goel and Thakor, 2008). 
Effects of Managerial Overconfidence on the Relationship between Corporate Risk-Taking and Firm Value

오히려 하락할 수 있음을 동시에 설명한다. 투자를 위한 자본조달 결정과 관련해 Heaton(2002), Malmendier and Tate(2005)는 경영자가 투자 안의 현금흐름이나 기대수익률을 낙관 또는 과신하는 경우 과소투자 및 과대투자 문제가 유발되어 기업이 적정 위험수준을 보유하지 못할 수 있음을 이론적으로 설명하였다. 실증분석에서는 주로 경영자 과신으로 인한 과도한 위험추구의 부정적 효과가 주목되어 왔는데, 대표적인 예로 기업의 인수합병 시장을 들 수 있다. 경영자의 과신은 가치평가오류를 통해 과도한 인수프리미엄을 지불하게 하거나, 가치하락 위험이 높은 인수합병의 착수를 증가시킬 수 있다고 알려져 있다(Hayward and Hambrick, 1997; Malmendier and Tate, 2008; Billett and Qian, 2008). 뿐만 아니라 경영자가 과신하는 기업의 대규모 R\&D 투자의 경우 그렇지 않은 기업의 투자에 비해 가치 증가효과를 얻지 못할 수 있다(Chen et al., 2014). 투자정책 이외에도 경영자의 과신은 투기 목적의 파생상품 사용을 확대해 기업의 위험관리정책을 왜곡시키거나(Adam et al., 2015), 기업의 미래 이익을 낙관적으로 전망하게 함으로써 추후 불리한 인수합병의 원인으로 작용하기도 한다(Hribar and Yang, 2016). 이같이 기업의 위험추구와 기업가치의 관계에서 경영자의 과신의 역할은 두 가지 상반된 예측이 모두 가능하므로 본 연구는 다음 가설을 설정한다.

가설 1: 기업의 위험추구와 기업가치의 관계는 경영자의 과신 여부에 따라 차별적일 것이다.

가설 1 이 성립할 경우, 과신의 효과를 강화 또는 통제하는 요인을 찾기 위해 본 연구는 기업 내부 지배구조(이사회, 재벌 통제), 외부 지배구조(시장 불확실성, 시장 경쟁), 그리고 경영자 인적 특성(나이) 변수를 이용해 추가 검증을 실시한다.

선행연구들은 사외이사 비중을 증가시키거나, 이사회 의장과 대표이사의 분리 등 이사회의 독립적인 역할이 과신으로 인한 가치 훼손을 줄일 수 있다고 주장한다(Hayward and Hambrick, 1997; Heaton, 2002; Malmendier and Tate, 2005; Goel and Thakor, 2008; Park et al., 2013). 사외이사는 경영자와 독립적일 것이라는 전제 하에 경영자를 모니터링 함으로써 그들의 독단적 판단을 통제하고, 경영에 대한 조언을 통해 경영자의 합리적 판단을 유도할 수 있다. 대표이사와 이사회 의장이 분리되어 있는 기업은 이사회의 감시를 통해 경영자의 비합리적 의사결정도 통제될 것이다. 그러나 이사회의 경영자 과신에 대한 조절 효과는 유효하지 않을 가능성도 있다. 이사회가 사외이사 구성이나, 이사회 의장 분리 등을 통해 형식적인 독립성을 확보를 했다하더라도 실질적인 경영 감시 및 통제활동을 하지 못할 수도 있기 때문이다(Bhagat and Black, 1999, 2002; Fields and Keys, 2003).5)

국내 사외이사 선임은 1998년 이후 현재까지 법적 규제로 강제되고 있으며(Kim, 2006), 제도 변경으로 사외이사 선임 비중이 기간에 따라 상이하다. 본 연구는 이러한 점을 고려해 이사회 독립성의 대용변수로 단순한 사외이사 비중이 아닌, 법정 요건을 초과해 사외이사를 선임하고 있는지의 여부를 이용해 조절효과를 검증한다. 추가로 사외이사를 비롯한 경영진과

5) 뿐만 아니라 사외이사의 전문성과 책임성이 부족한 경우에도 경영자 통제 효과가 나타나지 않을 수 있다. 그러나 사외이사의 전문성 및 책임성을 직접 변수화하기에 한계점이 있으므로 본 연구 분석에는 포함시키지 못하였다. 따라서 이와 관련된 논의는‘5. 결론 및 시사점’에 언급하였다. 
한국증권학회지 제48권 5호 (2019)

이사회 의장 분리 등 이사회 구조 및 운영에 관한 이사회 기능을 총체적으로 확인할 수 있는 한국기업지배구조원의 이사회 평가 점수를 활용해 전반적인 이사회 역할이 경영자의 과신적 의사결정을 통제할 수 있는지 검증한다.6) 이사회의 경영진 과신에 대한 조절효과 역시 상반된 예측이 모두 가능하므로 다음과 같은 가설을 설정하였다.

가설 2: 기업의 위험추구와 기업가치의 관계에서 경영자의 과신 여부의 효과는 '이사회의 통제'에 따라 차별적일 것이다.

가설 2-1: 기업의 위험추구와 기업가치의 관계에서 경영자의 과신 여부의 효과는 '사외이사 초과 선임'에 따라 차별적일 것이다.

가설 2-2: 기업의 위험추구와 기업가치의 관계에서 경영자의 과신 여부의 효과는 '양호한 이사회 역할'에 따라 차별적일 것이다.

한편 국내 재벌 집단 소속 기업들은 재벌 본부 기업을 중심으로 인적-경제적 자원을 공유하고 소유구조가 밀접하게 연관되어 있기 때문에 독립적인 기업임에도 불구하고 재벌 본부의 통제를 받는다(Chang and Shin, 2006). 이와 관련해 Park et al.(2013)는 재벌집단이 소속 기업 경영자의 독단적 의사결정과 위험감수 성향을 통제함으로써 경영자 과신의 통제 역할을 할 수 있다고 보고하였다. 그러나 재벌 의 경우 그룹 내 위험공유나 상호지원에 따라 부정적 사건에 대한 기대파산비용이나 재무제약에 처할 가능성을 낮출 수 있다(Bae and Lim, 2003). 때문에 이러한 효과에 대한 재벌 내 경영자의 기대가 높을 경우 투자 안을 실행함에 있어 실제 위험을 과소평가하는 인지적 편의에 노출될 가능성 역시 고려해볼 수 있다. 따라서 가설 1 에서 경영자 과신의 효과가 부정적일 경우, 재벌 소속 기업이라 하더라도 그러한 부정적 효과가 감소되지 못하거나 심화될 개연성이 충분하다. 결과적으로 재벌 집단 소속 여부 역시 이사회의 경우와 마찬가지로 경영자의 과신 효과를 조절하는데 상반된 결과를 모두 예상해 볼 수 있어 다음 가설을 설정하였다.

가설 3: 기업의 위험추구와 기업가치의 관계에서 경영자의 과신 여부의 효과는 '재벌집단의 소속 여부'에 따라 차별적일 것이다.

불확실성이 높은 상황에서 경영자는 객관적인 정보에 근거하기보다 자신의 주관적인 재량에 의존해 과신할 가능성이 존재하며, 이로 인해 강한 위험추구성향을 보일 수 있다(Tang et al., 2016). 높은 불확실성 하에서 과신 성향의 경영자가 기업의 과소투자 문제를 완화시키는 것 역시 불확실 상황에서 경영자의 위험추구가 증가하고 있음을 보여준다(Kang et al., 2017) 반면, 과신 성향의 경영자가 외부 불확실성이 낮은 상황을 우호적인 경영환경으로 인식하는 경우 이들의 과신 확률은 증가할 수 있으며, 이에 따른 위험추구 행태는 강화될 수 있다. 결국

6) 이사회의 기능과 관련해 이사회의 실질적인 독립성은 경영자에게 우호적이지 않은 독립적인 사외이사의 역할이 더 중요할 수 있다(Kang and Kook, 2012). 본 연구는 분석기간 전체를 대상으로 (i) 경영자의 인명 자료 수집이 제한적이며, (ii) 사내이사 역시 경영 감독기능을 수행할 필요가 있음을 토대로 이사회 전체의 지배구조 수준을 평가할 수 있는 한국지배구조원의 평가 자료를 활용하였다. 
Effects of Managerial Overconfidence on the Relationship between Corporate Risk-Taking and Firm Value

불확실성의 증가 및 감소 경우 모두 과신에 따른 위험추구에 영향을 줄 수 있다. 본 연구는 불확실성이 경영자 과신과 위험추구에 양(+)의 조절효과를 준다는 Tang et al.(2016)의 선행 연구와, 이후 <표 $3>$ 의 기초통계를 통해 국내 경영자 과신 기업의 경우 그렇지 않은 기업에 비해 위험추구가 높다는 측면에서 불확실성을 완화시키는 것의 효과를 기준으로 과신의 조절효과에 대한 방향성과 유의성을 검증하기로 한다.

한편, 다양한 외부 불확실 요인 가운데 경제정책 불확실성은 기업이 통제 불가능한 외생적인 요인이며, 금융위기와 같은 시장 불확실뿐만 아니라 경제정책의 불확실 요인을 두루 반영하고 있다. 뿐만 아니라 해당 변수는 국내 기업의 투자, 고용 등 위험추구 의사결정과 관련성이 높은 것으로 알려져 있다(Park and Hahn, 2017). 특히 경제정책 불확실성 변수는 기업 외부의 정책적 노력에 의해 과신의 효과가 조절될 수 있는지 검증 가능하게 한다.7) 따라서 외부 지배구조 관점에서 정부 정책 차원의 불확실성 완화가 경영자의 과신 효과를 조절하는지 가설 4 를 통해 확인한다.

가설 4: 기업의 위험추구와 기업가치의 관계에서 경영자의 과신 여부의 효과는 '경제정책의 불확실성'에 따라 차별적일 것이다.

시장 경쟁의 확대는 기업의 시장 환경을 보다 복잡하게 함으로써 결국 경영자의 의사결정에 재량권을 높일 수 있다(Hambrick and Finkelstein, 1987). 이에 따라 높은 시장 경쟁은 과신하는 경영자의 재량적 판단에 근거한 위험추구 행태를 강화시킬 수 있다(Li and Tang, 2010). 반대로 오히려 시장 경쟁의 확대가 경영자의 위험추구에 관한 의사결정을 통제하는 지배구조 역할을 할 가능성도 있다. 경쟁 위협 하에서 기업은 높은 투자위험과 파산확률을 부담해야 하므로, 경영자는 보수적인 의사결정을 하며 위험을 덜 추구할 수 있게 된다(Griffith, 2001). 따라서 시장의 경쟁 확대는 과신 경영자의 재량권 확대를 통해 기업의 위험추구를 강화시킬 수 있는 반면, 오히려 과신 성향을 지닌 경영자의 보수적인 의사결정을 유도해 위험추구행태를 약화시킬 수 있다. 본 연구는 시장 경쟁의 조절역할에 대해서도 다음과 같은 중립적인 가설을 설정한다.

가설 5: 기업의 위험추구와 기업가치의 관계에서 경영자의 과신 여부의 효과는 '산업 내 경쟁 정도'에 따라 차별적일 것이다.

경영자 과신의 효과를 조절하는 마지막 요인으로 경영자의 나이를 고려한다. 다른 인적 특성 변수 중에서도 나이는 명확히 관찰 가능한 특성 중 하나이며, 생애 동안 형성된 다양한 경험과

7) Kang et al.(2017)은 관세 인하 및 금융위기와 같이 경제 불확실성이 높은 경우, 경영자의 과신이 과소투자문제를 완화해 기업가치를 제고시킬 수 있다고 주장한다. 본 연구는 외생적인 불확실 요인을 개별적으로 사용하는 것이 아니라, 경제정책 및 시장 불확실 요인을 모두 반영하고 특히 외부 정책적 노력에 의해 과신이 조절될 수 있는지 검증하기 위해 Kang et al.(2017)과 달리 경제정책 불확실 변수를 활용했다. 또한 본 연구는 불확실성과 관련한 특정 기간(예로, 금융위기)만을 대상으로 분석하는 것이 아니라 보다 장기간을 대상으로 불확실성의 경영자 과신의 조절효과를 분석하고 있어 Kang et al.(2017) 연구와 차이가 있다. 
한국증권학회지 제 48 권 5 호 (2019)

정보를 바탕으로 개인의 사고 및 의사결정과 밀접하게 연관되어 있는 변수이다(Rhodes, 1983; Taylor, 1975). 이러한 나이는 투자 및 재무의사결정을 포괄하는 기업의 위험 추구 행태에 영향을 줄 수 있는데(Barker and Mueller, 2002; Betrand and Schoar, 2003; Yim, 2013; Serfling, 2014), 특히 나이가 많은 경영자는 젊은 경영자에 비해 자신의 명성과 성공을 얻기 위한 필요성과 부담(career concerns)을 상대적으로 적게 느낄 수 있다(Hambrick and Fukutomi, 1991). 따라서 젊은 경영자에 비해 나이가 많은 경영자는 상당한 직무 도전에 처할 가능성이 낮고, 의사결정에 있어 심리적 성향 및 편의에 영향을 덜 받아 결국 과신의 효과를 낮출 수 있다(Tang et al., 2016). 한편 나이가 많은 경영자가 조직 내 다수의 성공을 경험한 경영자일 수 있다는 측면에서 오히려 과신에 노출되기 쉬울 수 있다. 그러나 과신 성향의 경영자가 그러한 성공을 바탕으로 조직 내 경쟁 과정에서 높은 지위에 오를 수 있음에도 불구하고, 가설 1에서 과신의 효과가 만약 부정적인 경우라면 해당 지위를 오래 유지하기는 어려웠을 것이다(Goel and Thakor, 2008). 또한 경영자의 재직 기간은 나이에 비례할 가능성이 있어, 결국 기업 내 나이가 많은 경영자들은 과신하기보다는 상대적으로 합리적인 의사결정을 통해 지속적으로 경영진에 남아있을 가능성도 있다. 만약 가설 1 의 경영자 과신 효과가 부정적(긍정적)이라면, 나이가 많은 경영자 집단에서 과신의 부정적(긍정적) 효과가 완화될 것으로 기대된다. 이에 따라 마지막 조절 효과에 대한 가설 역시 다음과 같이 설정해 본다.

가설 6: 기업의 위험추구와 기업가치의 관계에서 경영자의 과신 여부의 효과는 '경영진의 평균 나이'에 따라 차별적일 것이다.

\section{3. 연구방법}

\section{1 경영자 과신 변수}

과신 자체는 심리적 속성이기 때문에 경영자의 과신을 정확히 측정하기란 쉽지 않다. 그럼에도 선행연구들은 다양한 대리 변수를 통해 경영자의 과신 여부나 그 정도를 측정하고 관련된 영향력을 검증해왔다.

기존 연구에서 사용된 경영자 과신 대용 변수의 속성은 경영자의 과신을 유도하는 원인과, 그로 인해 드러나는 의사결정 결과로 대별된다. 주로 선행연구들은 과신 원인 또는 결과를 설명하는 변수 가운데 1 2가지를 선택해 개별 모형에 각각 적용하거나, 과신의 결과를 추론하는 변수들을 조합해 과신의 효과를 검증해 왔다. 예로 Malmendier and Tate(2005, 2008)는 과신 원인과 관련된 미디어 칭찬 자료와 과신의 결과를 추정해볼 수 있는 스톡옵션 자료를 연구 모형에 각각 활용했다. Schrand and Zechman(2012)의 연구에서는 스톡옵션 자료 이외에도 투자와 재무의사결정과 관련된 복수의 변수를 과신 추론에 사용했다.8)

8) Hill et al.(2014)은 재무, 전략 분야에서 주로 사용되는 7가지 경영자 과신 대용변수의 타당성 분석 시행 이후, 변수 타당성 문제에 대한 일부 대안으로 복수의 변수 사용을 권고한 바 있다. 
Effects of Managerial Overconfidence on the Relationship between Corporate Risk-Taking and Firm Value

그런데 Malmendier and Tate(2005, 2008)의 방법으로 경영자 과신을 구분하는 방법은 표본선택편의 문제 뿐 아니라, 스톡옵션 부여 및 행사비중이 낮은 국내 기업에 적용되기 어렵다. 더욱이 과신 원인(결과)에 해당하는 미디어 칭찬(스톡옵션) 자료를 개별적으로 활용하는 경우 실제 과신 결과로 이어졌는지(과신 원인이 있었는지) 확인되지 않아 과신에 해당하는 표본 수가 과대 추정될 가능성이 있다. 따라서, 스톡옵션 및 미디어 자료의 활용 가능성을 차치하더라도 경영자 과신을 추론하기 위해 과신 원인 또는 결과에 해당하는 단일 변수만 활용하는 것은 적절치 못할 수 있다.9)그 밖에 선행연구에서 활용되고 있는 Schrand and Zechman(2012)의 방법 역시 사용된 변수의 범주가 모두 과신의 결과에 해당하며, 과신 이외의 다른 기업 특성을 포함할 수 있다는 점, 이론 및 실증 검증이 모호한 변수가 일부 활용된다는 점 등에서 한계가 있다.10)

이에 본 연구는 이론 및 실증 결과가 뒷받침되고 경영자 과신의 원인과 결과에 해당하는 복수 변수의 조합으로부터 과신 기업을 선별했다. 구체적으로 경영자 과신 성향을 유도하는 원인 중 하나인 최근의 성공적인 기업성과(Hayward and Hambrick, 1997)가 있는 기업을 대상으로, 과신으로 인해 나타나는 결과인 투자, 부채, 경영자의 자발적 이익 공시(Malmendier and Tate, 2005; Barros and Silverira, 2007; Hribar and Yang, 2016) 자료를 이용해 적어도 과신 성향의 경영자가 존재할 가능성이 높은 표본을 최종 선정했다.

경영자의 과신 여부 추론을 위해 위의 4 가지 변수를 선정한 근거는 다음과 같다. 첫째, 최근의 기업의 높은 성과는 자기 귀인(self-attribution) 관점(Miller and Ross, 1975)에서 경영자의 자존감, 업무 자신감, 통제 능력 등을 강화시킬 수 있어 과신의 원인이 될 수 있다(Hayward and Hambrick, 1997; So et al., 2014). Hayward and Hambrick(1997)은 자기 귀인 관점에서 과신의 다른 원인 변수로 미디어의 칭찬이나 다른 임원에 비해 상대적으로 높은 보수를 또한 지목했는데, 높은 기업성과는 이러한 다른 원인 변수들과도 연관된다. 이는 만약 기업이 우월한 성과를 보였다면 해당 기업의 경영자는 미디어의 칭찬에 노출될 확률이 높아질 수 있고, 조직 내 높은 지위와 보수를 얻게 될 확률 또한 높아질 수 있기 때문이다. 둘째, 투자, 부채, 경영자의 자발적 및 낙관적 이익 공시의 경우 과신으로 표출되는 행태인 '예측 오류(miscalibration),

9) $\mathrm{Kim}$ and $\operatorname{Ryu}(2014), \mathrm{Ryu}$ and $\operatorname{Kim}(2015)$ 는 산업평균대비 자본적 지출의 크기만을 이용해, 전체 표본의 절반 이상을 과신 표본으로 식별했다. 해당 연구들의 상당기간이 국내 기업의 투자위축을 우려하는 기간임을 고려할 때 과신 기업 수는 과대하게 추정되었을 가능성이 있다.

10) Schrand and Zechman(2012)은 과신의 추론 변수 중 하나로 산업조정 초과 레버리지(=부채/ 자기자본)를 활용하고 있는데, 레버리지의 증가는 경영자의 과신 성향뿐만 아니라 기업의 파산위험을 설명할 가능성도 있으며, 과신하는 경영자의 자본구조 의사결정은 현재까지 일치된 이론 및 실증 결론이 없다는 점에서 본 연구는 해당 레버리지 변수를 사용하지 않았다. 특히 후자인 자본구조 관점에서 레버리지는 다음과 같이 상반된 설명이 가능하다. 경영자가 낙관(과신의 한 속성인)하는 경우 경영자는 해당 기업의 주가가 시장에서 저평가되고 있다고 믿기 때문에 주식을 통한 자본조달 비용이 높다고 생각해, 순위이론에 따라 내부자금, 부채, 주식 순으로 자금을 조달하게 된다(Heaton, 2002). 반면, 미래 이익 변동성 또는 위험을 과소평가하는 과신 성향의 경영자는 해당 기업의 부채가 시장에서 과소평가되어 상대적으로 부채의 자본조달비용을 높게 인식하는 반면 주식의 기대수익률이 기초자산의 기대수익률 보다 높다고 판단(Jensen's Inequality)하기 때문에 내부자금, 주식, 채권 순으로 자본을 조달할 수 있다(Baker and Wurgler, 2013: 396). 
한국증권학회지 제 48 권 5 호 (2019)

평균 이상 효과(better than average effect), 통제의 환상 효과(illusion of control)'와 연관이 있다. 즉 과도한 투자 실행 및 부채의 사용은 투자 안의 성과와 자금조달비용에 대한 예측 오류나, 투자 및 자금조달 리스크에 대한 통제 능력을 과신해 초래된 결과일 수 있다. 낙관적 이익 전망 역시 과신으로 인한 이익의 예측 오류와 이익을 실제보다 과대하게 추정하는 일종의 평균 이상 효과를 반영하며, 국내 이익 공시는 현재 자발적 공시로 이루어지는데 특히 과신하는 경영자의 행태와 연관이 높다(Hribar and Yang, 2016).

경영자 과신 측정을 위한 각 변수의 세부 추정방법은 다음과 같다. 먼저 과신의 원인과 관련해 Hayward and Hambrick(1997)의 방법에 따라 전년도 배당을 포함한 주식수익률이 연도 및 산업 내 중위수 이상인 경우 경영자가 일차적으로 과신할 가능성이 존재하는 과거 성과가 좋은 기업으로 분류했다.11) 이후 높은 과거 성과는 경영자의 합리적 의사결정의 결과일 수 있으며 과신의 원인으로 작용하지 않을 수 있으므로, 앞서 언급한 3가지 과신 결과를 측정하는 투자, 부채, 낙관적 전망 변수를 추가로 고려했다.

과신적 투자 수준은 기존 연구들의 추정 오차를 보완하기 위해 다음과 같은 3 가지 방법을 활용했다. 먼저 Schrand and Zechman(2012)의 과신적 투자를 구분하는 방법을 토대로 총자산 성장률을 매출액 성장률에 회귀하여 잔차를 구하되, 투자가 내부자금 및 대리인 문제 관점에서 현금흐름에 영향을 받을 수 있다는 점을 고려해 모형에 현금흐름 변수를 추가하였다. 이후 해당 투자방정식의 잔차가 산업 내 중위수 이상(즉, 산업 조정 초과 투자가 0보다 클 경우)이면 과신적 투자로 판단했다. 둘째, Schrand and Zechman(2012) 모형에 현금흐름을 추가할 경우 Fazzari et al.(1988)의 투자방정식 형태가 되므로, Fazzari et al.(1988) 모형을 이용해 모형 내 잔차가 산업 내 중위수 이상인 경우 과신적 투자로 판단했다. 마지막으로 Campbell et al.(2011), Campbell(2014)의 방법을 준용해 자본적 지출(자본적 지출/총자산)을 기준으로 2년 ( $\mathrm{t}-1 \sim \mathrm{t})$ 연속 산업 조정 투자가 상위 $20 \%$ 에 속할 경우 경영자가 과신 성향을 갖는다고 판단했다. 다만 이 경우 투자방정식의 잔차를 활용한 경우와 마찬가지로 대리인 문제로 인해 과대 투자할 가능성을 배제할 필요가 있으므로 연도 내 성장기회가 낮으면서(Market to Book ratio가 중위수 미만), 잉여현금흐름이 높은(현금흐름/총자산이 중위수 이상) 기업은 과신 후보군에서 제외했다.

과신으로 인해 부채 사용이 높은지의 여부는 Ben-David et al.(2013)이 확인한 부채비율 (=이자지급 성 부채/총자산)을 이용해, 산업 내 중위수 보다 부채비율이 높은 경우로 정의했다. 다만 높은 부채비율이 경영자의 과신 성향을 반영하더라도, 이자 부담이 높은 경우는 과신 성향을 갖기 어렵다고 판단해 측정 표본에서 제외했다. 이는 과신 성향의 경영자가 기업의 상환 위험을 과소평가해 부채를 증가시킬 수 있지만(Hackbath, 2008), 높은 부채 사용에도 불구하고 원금과 이자의 상환 부담이 심각한 기업은 경영자가 재무 위험을 과소평가하기 어렵고 기업 성과가 부진한 상태였을 가능성이 높을 것이란 판단에 근거한다.

11) 본 연구가 과신 원인 및 결과를 모두 이용해 과신기업을 추론하고 있음에도 불구하고, 주가 성과가 좋아지자마자 경영자가 바로 과신하기 쉽다는 논리가 성립하기 어려울 수 있다. 따라서 전년도(t-1) 주가수익률 대신 이전 기간 $(\mathrm{t}-2, \mathrm{t}-3)$ 년 주가수익률을 이용하거나, 과거 2 년 $(\mathrm{t}-2 \sim \mathrm{t}-1)$ 및 과거 3 년 (t-3 t-1) 주가수익률의 평균자료를 활용해 과신 기업 추론에 활용했으나 결과는 큰 차이가 없었다. 
Effects of Managerial Overconfidence on the Relationship between Corporate Risk-Taking and Firm Value

마지막으로 경영자의 낙관적 이익 전망 공시가 존재하는 경우 경영자가 과신했을 가능성이 높다고 판단했다. 먼저 연도별-기업별 수준에서 자발적으로 연간 영업이익, 경상이익, 법인세 차감전 순이익, 당기순이익을 보고한 기업 가운데, 전망 대상년도의 이익을 이전 대비 축소해 보고하거나 또는 전망 이익이 실제보다 낮아 이익을 보수적으로 전망한 경우를 제외한 나머지 표본을 낙관적인 이익 전망 기업이라고 판단했다.12) 이때 기업이 개별재무제표가 아닌 연결재무제표를 기준으로 이익을 보고한 경우에는 연결재무제표 상의 실제 이익과 대응시켜 낙관적 전망 여부를 검토했다. 또한 기업이 이익을 예측한 대상년도가 1 년 이상인 경우는 재무제표의 확인 가능한 시점까지 비교하여 각 전망대상 년도의 [(미래 전망이익t-미래 실제이익 $\mathrm{t}$ /미래 실제이익t]의 평균이 0보다 큰 경우만 낙관적 전망 대상 기업으로 판단하였다.13)

이상의 과정을 통해 과신 원인과 결과 변수를 조합해 추론된 최종적인 경영자 과신 변수는 $O C 1, O C 2, O C 3$ 로 3개 더미 변수이다. $O C 1$ 의 경우 연도별 산업내 과거 성과가 높은 기업 중에서, Schrand and Zechman(2012)의 방법을 보완한 산업 조정 초과투자 기업 또는 산업 조정 초과 부채 기업 또는 낙관적 이익 예측 여부 중 2개 이상 만족하는 경우의 더미 변수이다. $O C 2$ 와 $O C 3$ 는 과신 여부 판단에서 Schrand and Zechman(2012)의 방법 대신 Fazzari et al.(1988)모형 또는 Campbell et al.(2011), Campbell(2014)을 토대로 도출한 과신적 투자성향 자료를 각각 이용한 경우의 더미 변수이다. 참고로 본 연구는 최고경영자 이외의 주요 경영진들 역시 과신할 가능성이 있음(Goel and Thakor, 2008; Ben-David et al., 2013)을 고려해 최고경영자 수준이 아닌 기업 수준에서 경영자 과신 기업을 추정하고 있다.

\section{2 위험추구 및 기업가치 변수, 통제변수}

기업의 위험추구 수준은 다수의 선행연구에서 활용된 연구개발투자 비율 $(R N D)$ 과 일별 주식수익률의 변동성 $R E T V O L)$ 을 이용한다. 연구개발투자비율은 기업의 투자활동 중에서도 그 결과가 높은 불확실성을 내포한다는 측면에서 위험추구의 대용변수로 주로 활용되는 변수이다(Galasso and Simcoe, 2011; Hirshleifer et al., 2012; Chen et al., 2014). 주식수익률 변동성 자료는 효율적 시장가설 하에서 위험추구와 관련된 전반적인 의사결정에 대한 정보를 즉각적으로 반영해주므로 관련 변수로 활용하였다(Hirshleifer et al., 2012). 기업가치의 대용변수는 선행연구에서 일반적으로 사용하는 Tobin's Q를 이용하였다.

12) 본 연구는 전망 시점과 전망대상 시점의 일정 시차(최소 3 개월)가 존재하는 연간 전망을 보고한 건만 활용했다. 또한 연간 전망이라 하더라도 사업연도 종료 후 3개월 이내(사업보고서 발표 전) 직전 사업연도를 대상으로 이익 예측을 공시한 건들은 이미 내부 경영성과 보고가 이루어졌을 가능성이 높아 실질적인 이익 공시로 보기 어려우므로 제외하였다. 한편, 전년대비 이익 감소를 보고한 경우일지라도 경영자가 과신할 가능성 있어, 이러한 기업을 제외하지 않은 경우를 추가 분석하였는데 실증분석결과는 지면에 보고한 결과와 질적으로 유사했다.

13) 2002년 11월 2016년 12 월까지 총 자발적 이익 예측공시(최초공시 기준) 건수는 1,879 건으로 이중 이익이 보고된 건수는 1,385 건(약 $74 \%$ ) 이었다. 또한 이익 보고 건수 가운데 이익을 전망한 기간은 최소 3 개월 최대 9 년까지였다. 본 연구에서 최종 낙관적 이익 예측으로 판별된 건은 545 건(전체 공시의 약 $29 \%$, 이익보고 공시의 $39 \%$ )이었다. 
한국증권학회지 제 48 권 5 호 (2019)

본 연구의 통제변수로는 기업가치를 주로 설명한다고 알려진 기업 규모(SIZE), 레버리지 $(L E V)$, 수익성 $(P R O F I T)$, 성장성 $(S G)$, 외국인 지분율 $(F O R)$, 내부 지분율 $(O W N)$, 현금흐름 $(C F)$, 기업 업력 $(F A G E)$ 을 이용한다. 과신과 기업가치 간의 내생성을 일부 통제하기 위해 통제변수에 기업가치의 대용변수인 Tobin's Q 1년 시차 값을 추가하며, 산업과 연도별 고유특성을 추가로 통제한다. 위험추구를 종속변수로 이용하여 사전 분석을 하는 경우는 투자기회의 대용변수로 보통주의 시가장부가 비율 $(M B)$ 을 포함시켰다.

\section{3 과신 조절 변수}

기업 내부 지배구조가 과신의 효과를 조절하는지 살펴보기 위해 사외이사 초과 선임 여부 더미, 이사회 점수 상위 기업 더미, 재벌의 소속 더미를 구성하였다. 이사회 초과 선임 여부는 연도 내 기업 규모별 법정 최소 사외이사 수를 초과하여 사외이사를 선임한 경우의 더미 $(O D)$ 변수로 측정했다. 이사회 점수 상위 기업 더미 $(S D)$ 의 경우 한국기업지배구조원의 지배구조 평가점수 하위 항목 중 해당 기업의 이사회 점수를 매년 이사회 점수 총점으로 표준화한 뒤, 표준화 점수가 연도 내 중위수 이상인 기업은 1 , 아니면 0 의 값을 부여했다.14) 재벌 소속 여부는 공정거래위원회가 매년 고시하는 대규모 기업집단 리스트를 활용해 공기업을 배제하고 기업 집단에 속하는 경우에 1 , 아니면 0 의 값을 부여했다.

외부 지배구조 차원의 조절 요인으로 먼저 시장 불확실성은 Baker et al.(2016)이 제시한 경제정책 불확실 지수(Economic Policy Uncertainty Index; EPU)를 이용해 표본 기간 내 불확실성이 낮은 연도 더미 변수 $(E D)$ 를 이용한다. EPU Index는 Baker et al.(2016)이 고안한 방법으로, 각국 주요 일간지에서 경제정책, 불확실, 정부, 규제 등의 단어가 공통적으로 언급되는 기사의 빈도로 개별 국가별로 계산되고 있다. 본 연구는 한국 지수의 월별 자료를 Park and

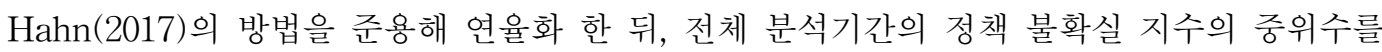
기준으로 하위 년도를 1 , 상위 년도에 0 의 값을 부여해 정책 불확실 하위 기간 더미 $(E D)$ 를 구성했다. 원 지수의 연율화는 2002년부터 2015년까지 전체 기간을 대상으로 지수가 가장 높은(낮은) 월은 $1(0)$ 로 표준화된 순위를 부여하고 이 순위 값을 연도별로 평균하였다.

두 번째 외부 지배구조 변수인 시장 경쟁 정도는 재무 분야에서 일반적으로 사용되는 허핀달허쉬만 지수(Herfindal-Hirshman Index; HHI)를 활용해 연도 내 경쟁 정도가 낮은 산업 더미 $(L D)$ (즉, $\mathrm{HHI}$ 가 연도 내 중위수 이상인 경우)를 구성했다. 본 연구는 국내 산업별 경쟁 정도를 확인하고자 유가증권시장 상장기업, 코스닥시장 상장기업, 그리고 외부감사법인의 매출액 자료를 활용해 한국표준산업분류 3자리에서 연도내 산업별 $\mathrm{HHI}$ 를 산출했다. HHI는 동일 산업 단위에서 기업의 매출액을 기준으로 시장점유율 제곱한 뒤 이를 모두 합산한 값으로 산출되며, 값이 상대적으로 높을(낮을) 경우 시장점유율이 특정(여러) 기업에 집중(분산)되어 있음을 의미하므로 경쟁강도가 낮은(높은) 산업으로 이해할 수 있다.

14) 한국기업지배구조원의 이사회 평가는 (i) 이사회 구성과 운영, (ii) 이사회 평가 및 보상, (iii) 이사회 내 위원회 등의 분류로 평가하고 있다. 본 연구의 분석기간 중 2005년 평가체계 변경으로 이사회 총 점수가 변경되었다는 점을 고려해 총 점수로 표준화하여 사용하였다. 
Effects of Managerial Overconfidence on the Relationship between Corporate Risk-Taking and Firm Value

마지막으로 경영자의 인적 특성인 나이 변수는, 등기 임원 중 감사를 제외한 전체 임원의 나이를 평균한 뒤, 이러한 경영진의 평균 나이가 연도 내 중위수 이상인 경우를 경영진의 평균 연령이 높은 기업 더미 $(A D)$ 로 구성하였다. 이상의 분석에 필요한 주요 변수는 <표 $1>$ 에 정리하였다.

\section{〈표 1〉 주요 변수의 정의}

아래의 표는 본 논문의 실증분석에 사용된 주요 변수를 정리한 것이다.

\begin{tabular}{|c|c|}
\hline 주요변수 & 변수설명 \\
\hline [종속 변수] & \\
\hline$Q_{t+1}$ & $\mathrm{t}+1$ 년 말 Tobin's $\mathrm{Q}=($ 주식시장가치 + 부채장부가치 $) /$ 총자산 $)$ \\
\hline \multicolumn{2}{|c|}{ [위험추구 변수] } \\
\hline \multicolumn{2}{|c|}{$R N D_{t} \quad \mathrm{t}$ 년 말 연구개발투자 비율(= 총 연구개발비/총자산) } \\
\hline RETVOL & $\mathrm{t}$ 년 주식수익률 변동성 (= 일별 주식수익률 표준편차) \\
\hline \multicolumn{2}{|c|}{ [경영자 과신 변수] } \\
\hline \multirow[t]{2}{*}{$O C 1_{t}$} & t년 경영자 과신 여부 더미 1 \\
\hline & $\begin{array}{l}\text { : } \mathrm{t}-1 \text { 년 산업 내 수가수익률이 중위수 이상 기업 중에서 } \\
\left.\left.\text { (주식수익률 }{ }_{t-1}=\left[\text { (기말주가 } t-1^{-} \text {기초주가 }{ }_{t-1}\right)+\text { 현금배당 }_{t-1}\right] / \text { 기초주가 }{ }_{t-1}\right) \\
\text { 고투자(*), 고부채, 낙관적 이익 전망 요건 중 } 2 \text { 개 이상 만족하는 기업(* Schrand } \\
\text { and Zechman(2012) 모형 수정) }\end{array}$ \\
\hline \multirow[t]{2}{*}{$O C 2_{t}$} & t년 경영자 과신 여부 더미2 \\
\hline & $\begin{array}{l}\text { : t-1년 산업 내 주가수익률 중위수 이상 기업 중에서 고투자 }(* *) \text {, 고부채, 낙관적 이익 } \\
\text { 전망 요건 중 } 2 \text { 개 이상 만족하는 기업(** Fazzari et al.(1988) 모형 이용) }\end{array}$ \\
\hline \multirow[t]{2}{*}{$O C 3_{t}$} & $\mathrm{t}$ 년 경영자 과신 여부 더미 3 \\
\hline & $\begin{array}{l}\text { : t-1년 산업 내 주가수익률 중위수 이상 기업 중에서 고투자(***), 고부채, 낙관적 이익 } \\
\text { 전망 요건 중 } 2 \text { 개 이상 만족하는 기업(*** Campbell et al.(2011), Campbell(2014) 방법 } \\
\text { 수정) }\end{array}$ \\
\hline \multicolumn{2}{|l|}{ [통제 변수] } \\
\hline$S I Z E_{t}$ & $\mathrm{t}$ 년 말 기업규모 $(=\ln ($ 총자산 $))$ \\
\hline $\mathrm{PROFIT}_{t}$ & $\mathrm{t}$ 년 수익성 (= 영업이익/매출액 ) \\
\hline$L E V_{t}$ & t년 말 레버리지(= 총부채/총자산 ) \\
\hline$M B_{t}$ & t년 말 시가장부가 비율 $(=$ 보통주 시장가치/장부가치 $)$ \\
\hline$S G_{t}$ & $\mathrm{t}$ 년 매출성장성 $(=($ 매출액 $\mathrm{t}-$ 매출액 $\mathrm{t}-1) / \mathrm{t}$ 년도 매출액 $\mathrm{t}-1)$ \\
\hline$F O R_{t}$ & t년 말 외국인지분율(= 외국인 보유주식수/발행주식 총수) \\
\hline$O W N_{t}$ & $\mathrm{t}$ 년 말 내부지분율 $(=$ 최대주주 및 특수관계자 보유주식수/발행주식 총수 $)$ \\
\hline$C F_{t}$ & t년 말 영업현금흐름(= 영업현금흐름/총자산) \\
\hline$F A G E_{t}$ & $\mathrm{t}$ 년 기업 업력 $(=\ln ($ 분석년도t-설립년도 +1$))$ \\
\hline$Q_{t}$ & t년 말 Tobin's Q \\
\hline \multicolumn{2}{|l|}{ [조절 변수] } \\
\hline$O D_{t}$ & $\mathrm{t}$ 년 말 사외이사 초과 선임 기업 더미 \\
\hline$S D_{t}$ & $\mathrm{t}$ 년 지배구조평가원 이사회 점수 상위 기업(연도내 중위수 이상) 더미 \\
\hline$C D_{t}$ & $\mathrm{t}$ 년 말 재벌집단 소속 기업 더미 \\
\hline$E D_{t}$ & t년 경제정책 불확실 하위 연도(연율화 EPI index 중위수 미만) 더미 \\
\hline$L D_{t}$ & t년 시장 경쟁 하위 산업(연도내 $\mathrm{HHI}$ 중위수 이상) 더미 \\
\hline$A D_{t}$ & t년 경영진 평균 나이 상위 기업(연도내 중위수 이상) 더미 \\
\hline
\end{tabular}




\section{4 연구 모형}

가설 1 의 검증을 위해 아래 식 (1)과 같은 회귀모형을 추정한다. 이때 성과가 높은 기업의 경영자가 과신할 가능성이 높다는 측면에서(Hayward and Hambrick, 1997) 일부 내생성 문제를 완화하기 위해 종속변수는 설명변수에 대해 1 시차 선행하도록 모형을 설계했다. 한편 가설 검정 시 이분산 문제를 감안해 모든 모형은 White방법으로 조정된 강건한 표준오차(robust standard error)를 이용했다.

$$
\begin{aligned}
Q_{i, t+1}= & \beta_{0}+\beta_{1} \operatorname{RISK}_{i, t}+\beta_{2} \operatorname{RISK}_{i, t} \times O C_{i, t}+\beta_{3} O C_{i, t} \\
& +\sum_{k=4}^{K} \beta_{k} \text { Controls }_{i, t}^{k t h}+\epsilon_{i, t}
\end{aligned}
$$

식 (1)의 설명변수인 위험추구 $(R I S K)$ 는 당해년도의 연구개발투자 $(R N D)$ 와 주가수익률 변동성 $(R E T V O L)$ 이며, 과신 경영자 기업 더미 $(\mathrm{OC})$ 는 경영자 과신의 원인-결과변수로 조합해 식별한 과신 경영자 기업더미 3가지 $(O C 1, O C 2, O C 3)$ 를 포함한다. 통제변수 $\left(C o n t r o l s s^{k t h}\right)$ 는 앞에서 설명한 변수 이외에도 산업더미와 연도더미를 포함한다. 만약 기업의 위험추구와 기업가치의 관계에서 경영자 과신이 해당 기업이 적정 위험 수준에서 벗어나 필요 이상 과도한 위험추구를 함으로써 기업가치를 하락시킨다면, $R I S K \times O C$ 의 계수 $\beta_{2}$ 는 유의적인 음 $(-)$ 의 값을 가질 것이다. 반면, 현재 기업의 위험추구 상황이 최적위험 수준보다 낮아 경영자의 적극적인 위험추구가 오히려 가치를 증가시킨다면, $\beta_{2}$ 는 유의적인 양 $(+)$ 의 값을 보일 것이다.

가설 2 부터 가설 6 과 같이 경영자 과신의 조절 역할에 대한 가설검정은 식 (2)를 이용한다. 이때 조절변수 $(M O D E R A T O R)$ 는 각각 사외이사 초과 선임 기업 더미 $(O D)$, 이사회 점수 상위 기업 더미 $(S D)$, 재벌소속 기업 더미 $(C D)$, 경제정책 불확실성 하위 연도 더미 $(E D)$, 시장 경쟁 하위 산업 더미 $(L D)$, 경영진 평균 나이 상위 기업 더미 $(\mathrm{AD})$ 를 각각 의미한다. 통제변수 $\left(\right.$ Controls $\left.^{k t h}\right)$ 는 식 (1)에서 통제변수 뿐만 아니라, RISK, OC, MODERATOR 개별 변수와 변수 간에 조합(combination)에 의한 통제 변수들을 모두 포함한다. 만약 기업의 위험추구와 기업가치의 관계에서 경영자 과신의 효과를 조절하는 요인이 존재하는 경우, 해당 $R I S K \times O C \times$ $M O D E R A T O R$ 변수의 계수 $c_{3}$ 는 유의한 값을 가질 것이다. 반면 조절 변수(MODERATOR)들 대부분이 선행연구들의 예측과 달리 과신의 효과를 증가 또는 감소시킬 수 있는 논리적 근거를 모두 갖고 있으므로 두 효과가 상쇄된다면 위 교차항의 계수 $c_{3}$ 는 유의하지 않을 가능성도 있다.

$$
\begin{aligned}
Q_{i, t+1}= & c_{0}+c_{1} \operatorname{RISK}_{i, t}+c_{2} \text { RISK }_{i, t} \times O C_{i, t} \\
& +c_{3} \text { RISK }_{i, t} \times O C_{i, t} \times \text { MODERATOR }_{i, t}+\sum_{k=4}^{K} c_{k} \text { Controls }_{i, t}^{k t h}+\mu_{i, t}
\end{aligned}
$$

\section{5 자료 및 표본}

본 논문의 분석 대상은 국내 유가증권시장 상장기업으로 2002년부터 2015년까지 비 금융업종을 대상으로 한다. 분석기간을 2002년부터 선정한 것은 국내 기업들이 1990년 후반 외환위기의 
Effects of Managerial Overconfidence on the Relationship between Corporate Risk-Taking and Firm Value

영향에서 벗어나면서 경영 환경에 대한 경영자의 태도나 사고방식에 변화가 있을 가능성과, 경영자의 이익 공시 자료의 수집이 가능한 시기를 고려했기 때문이다. 재무자료와 경영자 인적사항 등은 한국상장사협의회 데이터인 TS-2000을 통해 수집하며, 수익률은 FnGuide 자료를 이용했다. 경영자 이익 공시 자료는 한국거래소 상장공시시스템(KIND)을 활용해 정리했다. 마지막으로 재벌집단 소속 기업은 공정거래위원회의 상호출자제한집단 명단을 참고하였으며, 국내의 경제정책 불확실 지수 원자료는 http://www.policyuncertainty.com에서 추출하였다.

$<$ 표 2>의 왼쪽(A)은 전체 표본을 대상으로 경영자가 과신하는 경우로 식별된 표본의 빈도수를 연도별로 정리한 것이다. 과신 추론을 위해 투자 수준 추정 시 투자방정식의 산업조정 잔차를 이용한 $O C 1, O C 2$ 를 기준으로 하는 경우 전체 표본의 약 8 9\% 정도가 경영자 과신이 있는 것으로 추론되었다. 투자방정식의 산업조정 투자 수준이 높은(상위 $20 \%$ 이상)경우를 과신 추론에 활용한 $O C 3$ 를 기준으로 할 경우 경영자 과신 기업수가 $4 \%$ 이하로 추론되어, $O C 1, O C 2$ 보다 엄격한 조건에서 과신 기업을 판별한 것으로 이해된다. 직접적인 비교는 불가능하지만, 국내 기업에서 전체 표본의 많게는 8 9\% 정도까지 경영자가 과신 성향이 있다고 판단하는 것은, 미국 기업을 대상으로 투자, 재무자료를 활용해 과신 경영자를 추론한 Schrand and Zechman (2012)의 약 47\% 보다 낮은 수치이다. 이는 Schrand and Zechman(2012)는 본 연구와 달리 과신 추론을 위해 원인 측정 변수를 고려하지 않으며 각 과신 결과 측정 변수가 갖는 일부 기업특성(예, 대리인 문제, 파산위험 등)을 배제하지 않았기 때문일 것으로 생각된다.

연도별 추이로는 주로 경기가 상승세이면서 주식 시장이 호황기인 2004 2007년이나, 글로벌 금융위기에서 벗어나 그리스 금융위기가 본격 논의되기 이전인 2010년에 과신하는 경영자가 상대적으로 많았던 것으로 보인다. 이는 불확실성이 상대적으로 낮은 우호적인 시장 환경 (munificent market condition)에서는 불확실성이 높은 시기에 비해 기업이 보다 많은 기회와 자원을 활용할 수 있으므로 결과적으로 경영자가 과신할 가능성이 높을 수 있음을 암시한다 (Hambrick and Finkelstein, 1987).15)

<표 2>의 오른쪽(B)은 본 연구에서 사용하는 과신 식별 기준의 타당성을 검토하고자, 과거 성과가 양호해 경영자 과신이 유도될 만한 기업을 대상으로 산업조정 투자, 산업조정 부채, 낙관적 이익전망 자료로 측정된 과신 결과 더미를 합산해 점수화한 것이다. $O C 1$ 을 예로 살펴보면 과거 성과가 양호한 3,814 개 표본 가운데 과신 결과 측정 변수를 기준으로 과신에 전혀 해당되지 않거나 $($ score $=0)$ 과신 가능성이 매우 낮은 표본 $($ score $=1)$ 이 총 3,095 개(성과가 양호한 표본 3,814 개 중 약 $81 \%$ )나 된다. 따라서 과신 원인 변수를 고려하더라도 단일 변수만을 활용할 경우 실제 과신하지 않을 가능성이 높은 기업의 상당수가 과신 기업으로 분류될 수 있음을 확인할 수 있었다. 또한 지면에는 생략하였지만 과거 성과가 비교적 부진해 과신 원인을 갖기 어려운 기업이 과신 결과로 측정되는 변수 기준을 충족(score> $=2)$ 하는 경우(542 679개 관측치)도 적지 않았다. 따라서 과신 원인과 그 결과를 조합해 경영자 과신 기업을 추론할 필요가 있음을 알 수 있었다.

15) 산업별로는 방송업, 비금속광물업, 의료정밀 등이 개별 산업 내 경영자가 과신하는 비율이 상대적으로 높았으며, 이를 통해 주로 산업 내 경쟁이 치열하지 않아 비교적 높은 진입장벽 내에서 경영하는 기업이 과신하기 쉽다는 점을 확인할 수 있었다. 관련 내용은 지면 관계상 생략한다. 


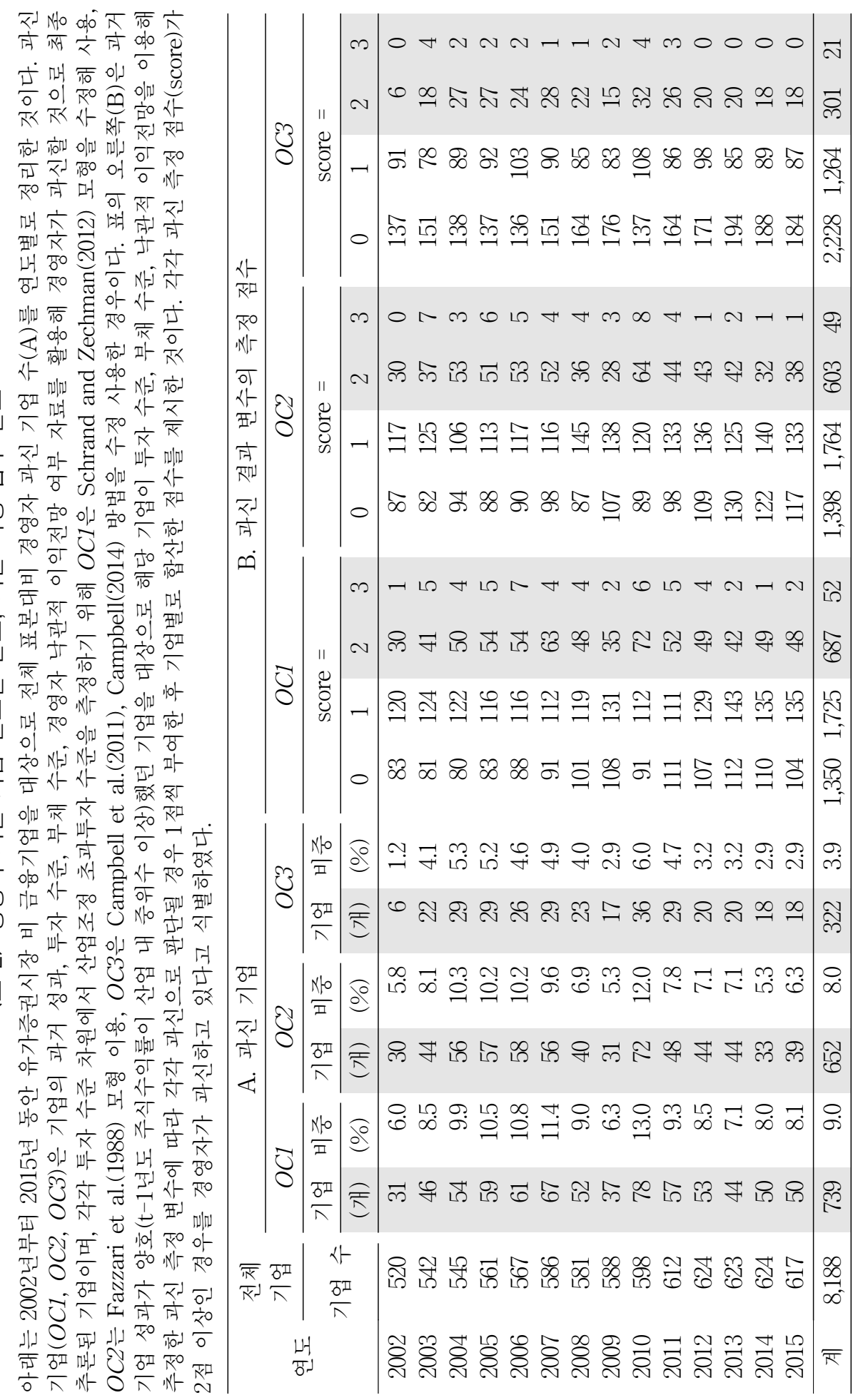


Effects of Managerial Overconfidence on the Relationship between Corporate Risk-Taking and Firm Value

\section{4. 실증분석}

\section{1 기초통계량}

<표 3>은 주요 변수들의 기초통계량이다. Tobin's $\mathrm{Q}(Q)$, 연구개발투자 $(R N D)$ 와 수익률 변동성 $(R E T V O L)$ 변수의 평균은 각각 $1.075,0.013,0.030$ 이었으며 각 변수의 최댓값과 최솟값을

\section{〈표 3〉기초 통계량}

아래의 표는 주요 변수의 기초통계량이다. $Q$ 는 Tobin's Q이며, $R N D$ 는 연구개발투자비율, RETVOL은 주식수익률 변동성, $O C 1, O C 2, O C 3$ 는 각각 경영자 과신 기업 더미이다. SIZE는 $\ln$ (총자산), PROFIT은 영업이익/매출액, $L E V$ 는 총부채/총자산, $M B$ 는 보통주 시가-장부가비율, $S G$ 는 매출액성장률, $F O R$ 은 외국인 지분율, $O W N$ 은 내부지분율, $C F$ 는 영업현금흐름/총자산, $F A G E$ 는 $\ln$ (업력) 값이다. 과신 조절 변수로 $O D$ 는 사외이사 초과 선임 기업 더미, $S D$ 는 이사회 점수 상위 기업 더미, $C D$ 는 재벌 소속 기업 더미, $E D$ 는 경제정책 불확실 하위 연도 더미, $L D$ 는 시장 경쟁 하위 산업 더미, $A D$ 는 경영진 평균 나이 상위 기업 더미이다. 괄호안의 $S C O R E, E P U, H H I, A G E$ 는 각각 이사회 점수, 연율화 한 경제정책 불확실 지수, 허핀달-허쉬만 지수, 경영진 평균 나이(세)이며 과신 조절 변수의 이해를 돕고자 제시했다. 모든 변수는 상하 $1 \%$ 의 극단치를 조정(winsorization)하였다.

\begin{tabular}{|c|c|c|c|c|c|c|}
\hline & $\mathrm{N}$ (개) & Mean & Median & Std. & Min. & Max. \\
\hline$Q_{t+1}$ & 8,188 & 1.075 & 0.920 & 0.612 & 0.288 & 6.264 \\
\hline$R N D_{t}$ & 8,188 & 0.013 & 0.004 & 0.021 & 0.000 & 0.139 \\
\hline RETVOL $L_{t}$ & 8,188 & 0.030 & 0.028 & 0.012 & 0.009 & 0.077 \\
\hline$O C 1_{t}$ & 8,188 & 0.090 & 0.000 & 0.287 & 0.000 & 1.000 \\
\hline$O C 2_{t}$ & 8,188 & 0.080 & 0.000 & 0.271 & 0.000 & 1.000 \\
\hline$O C 3_{t}$ & 8,188 & 0.039 & 0.000 & 0.194 & 0.000 & 1.000 \\
\hline$S I Z E_{t}$ & 8,188 & 26.533 & 26.286 & 1.512 & 23.160 & 31.159 \\
\hline PROFIT $_{t}$ & 8,188 & 0.038 & 0.039 & 0.070 & -0.330 & 0.271 \\
\hline$L E V_{t}$ & 8,188 & 0.442 & 0.447 & 0.204 & 0.012 & 0.952 \\
\hline$M B_{t}$ & 8,188 & 1.167 & 0.794 & 1.218 & 0.102 & 12.014 \\
\hline$S G_{t}$ & 8,188 & 0.074 & 0.047 & 0.322 & -0.898 & 3.709 \\
\hline$F O R_{t}$ & 8,188 & 0.099 & 0.034 & 0.139 & 0.000 & 0.688 \\
\hline$O W N_{t}$ & 8,086 & 0.419 & 0.416 & 0.166 & 0.050 & 0.842 \\
\hline$C F_{t}$ & 8,188 & 0.047 & 0.046 & 0.092 & -0.579 & 0.462 \\
\hline$F A G E_{t}$ & 8,188 & 3.460 & 3.638 & 0.673 & 0.693 & 4.466 \\
\hline$Q_{t}$ & 8,188 & 1.046 & 0.899 & 0.593 & 0.276 & 6.613 \\
\hline$O D_{t}$ & 8,103 & 0.173 & 0.000 & 0.378 & 0.000 & 1.000 \\
\hline$S D_{t}$ & 7,342 & 0.501 & 1.000 & 0.500 & 0.000 & 1.000 \\
\hline$\left(S C O R E_{t}\right)$ & 7,342 & 0.183 & 0.159 & 0.105 & 0.000 & 0.889 \\
\hline$C D_{t}$ & 8,188 & 0.239 & 0.000 & 0.427 & 0.000 & 1.000 \\
\hline$E D_{t}$ & 8,188 & 0.500 & 1.000 & 0.500 & 0.000 & 1.000 \\
\hline$\left(E P U_{t}\right)$ & 8,188 & 0.304 & 0.318 & 0.078 & 0.168 & 0.409 \\
\hline$L D_{t}$ & 8,188 & 0.501 & 1.000 & 0.500 & 0.000 & 1.000 \\
\hline$\left(H H I_{t}\right)$ & 8,188 & 0.178 & 0.127 & 0.149 & 0.008 & 1.000 \\
\hline$A D_{t}$ & 8,103 & 0.501 & 1.000 & 0.500 & 0.000 & 1.000 \\
\hline$\left(A G E_{t}\right)$ & 8,103 & 56.928 & 57.250 & 5.168 & 32.000 & 78.000 \\
\hline
\end{tabular}




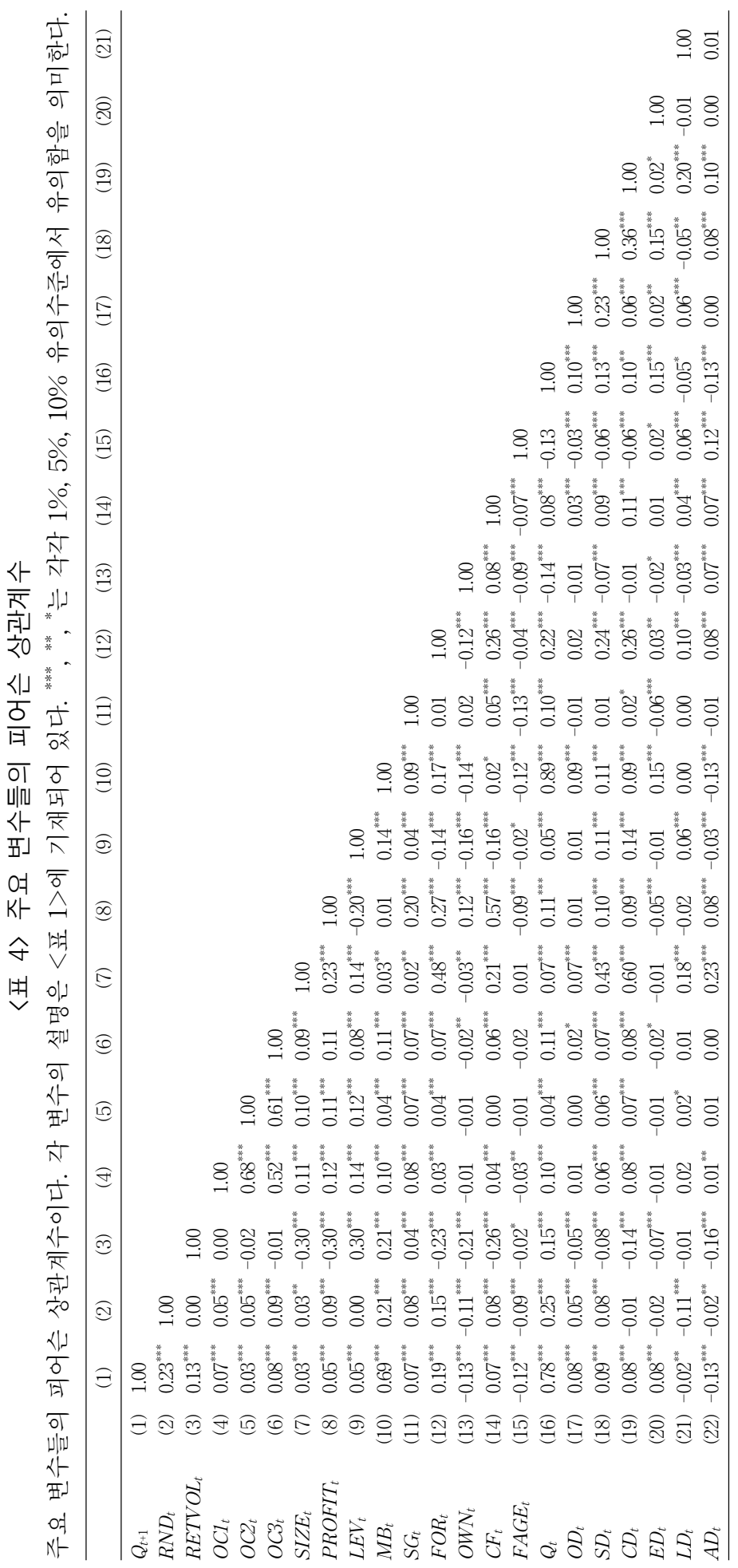


Effects of Managerial Overconfidence on the Relationship between Corporate Risk-Taking and Firm Value

고려해볼 때 기업별로 위험추구 수준에 따른 기업가치는 비교적 다양했음을 알 수 있다. 경영자 과신의 조절 역할로 기존 연구에서 주로 주목했던 이사회의 기능과 관련해, 이사회 독립성의 대용변수로 활용되는 사외이사 초과 선임 기업 더미 $(O D)$ 의 경우 중위수 0 , 평균 0.173 으로 나타나 대부분의 기업들이 최소한 형식적인 측면의 사외이사 제도를 수용하고 있음을 알 수 있었다. 이사회 평가 점수 상위 더미 $(S D)$ 의 산출 기초자료인 총점으로 표준화된 이사회 평가 점수(SCORE) 평균은 약 0.183 로 국내 유가증권시장 상장기업의 이사회 기능에 대한 평가가 양호하다고 보긴 어려웠다. 이는 국내 기업 실무에서 지배주주에 의한 경영관행이 일반화되면서 이사회가 제대로 기능하지 못할 수 있다는 점과 연관성이 있을 것이다. 이 밖에 국내 유가증권시장 상장기업의 등기임원 중 사외이사를 제외한 실제 내부 경영진의 평균 나이는 약 57 세 정도였으며 평균 나이는 최소 32세, 최대 78세 정도로 기업별로 경영진의 연령 분포가 매우 차별적임이 확인되었다.

<표 4>는 주요 변수들의 피어슨 상관계수가 제시되어 있다. 경영자 과신 더미인 $O C 1, O C 2$, $O C 3$ 의 상관관계는 $0.52 \sim 0.68$ 로 세 변수는 모두 $1 \%$ 수준에서 유의적인 양 $(+)$ 의 상관을 보여 설명변수 간 일관성을 확보할 수 있었다. Tobin's $\mathrm{Q}(Q)$, 연구개발투자 비율 $(R N D)$ 및 주식수익률 변동성 $(R E T V O L)$ 간에는 각각 양(+)의 유의적인 상관관계가 확인되어, 기업이 위험부담 대가로 수익을 창출하고 기업가치를 제고시키는 이른바 위험-수익 상충관계를 확인할 수 있었다. 일부 설명변수 간 상관관계가 다소 높은 변수가 있고, 교차항을 이용한 모형이 주로 분석에 활용되고 있지만, 모형별 분산팽창요인 검증 결과다중공선성 문제는 우려하지 않았다.

\section{2 경영자 과신 여부에 따른 차이분석}

<표 5>는 경영자 과신 더미를 기준으로, 주요 변수의 집단 간 차이를 분석한 것이다. 분석결과 경영자가 과신하는 경우 위험부담이 높고 혁신과 연관이 있는 연구개발투자 $(R N D)$ 를 증가시키고 있었다. 그러나 주가수익률 변동성으로 추정한 위험추구 관점에서는 두 그룹 간 통계적으로 유의한 차이는 확인할 수 없었다. 과신 기업의 경우 비 과신 기업에 비해 차년도( $\mathrm{t}+1$ 년 $)$ 기업가치 $(Q)$ 가 높게 나타났다. 그러나 과신 기업군들의 연구개발투자 $(R N D)$, 수익성 $(P R O F I T)$, 성장성 $(M B, S G)$ 이 비 과신 기업에 비해 통계적으로 높은 것으로 나타나 이러한 기업특성의 영향이 반영된 결과 일 수 있다는 것을 짐작케 한다. 따라서 과신 기업 여부에 따른 위험추구 및 기업가치의 관계는 다른 통제변수를 포함한 다변량 분석을 통해 확인할 필요가 있었다.

경영자가 과신하는 기업의 경우 수익성 $(P R O F I T)$, 성장성 $(S G)$, 레버리지 $(L E V)$ 가 높게 나타났다. 이러한 기업은 특히 연구개발투자 $(R N D)$ 와 같은 투자를 보다 많이 하는 기업으로, 동시에 성장기회 $(M B, S G)$ 가 높은 기업이며 레버리지 $(L E V)$ 가 높지만 수익성 $(P R O F I T)$ 과 현금흐름 $(C F)$ 이 동시에 높아 결국 내부자금 이용에 제약이 덜한 기업으로 볼 수 있다. 이를 통해 경영자가 과신하는 기업은 성장기회를 고려해 투자를 늘리되, 자본제약으로 인한 과소투자 문제(Malmendier and Tate, 2005)를 의심할만한 기업은 아닌 것으로 판단할 수 있었다. 따라서 추후 회귀분석결과에서 경영자 과신의 효과가 부정적일 경우, 이는 경영자 과신이 과소투자 문제와 같이 위험을 낮추는 의사결정을 유도했다기보다는 위험을 과대하게 추구했거나 해당 기업에 부적절한 위험추구 의사결정을 한 것에서 초래된 결과로 해석될 여지가 있었다. 
한국증권학회지 제48권 5호 (2019)

〈표 5〉경영자 과신 여부와 주요 변수 차이분석

주요 변수의 평균차이 검정 및 윌콕슨의 부호순위 검정 결과이다. 과신 기업 더미 $O C 2$ 와, $O C 3$ 를 기준으로 하는 분석은 지면 관계상 기업가치 $(Q)$ 와 위험추구 변수 $(R N D, R E T V O L)$ 만 제시한다. 주요 변수의 설명은 <표 $1>$ 과 같다. ${ }^{* * *}{ }^{* *}$, ${ }^{*}$ 는 각각 $1 \%, 5 \%, 10 \%$ 유의수준에서 유의함을 의미한다.

Panel A: $O C 1$ 기준

\begin{tabular}{|c|c|c|c|c|c|c|c|c|}
\hline \multirow{2}{*}{ 변수 } & \multicolumn{3}{|c|}{ 과신 기업 (a) } & \multicolumn{3}{|c|}{ 비 과신 기업 (b) } & \multicolumn{2}{|c|}{ 차이분석 (a-b) } \\
\hline & $\mathrm{N}$ (개) & mean & median & $\mathrm{N}$ (개) & mean & median & t-value & $z$-value \\
\hline$Q_{t+1}$ & 739 & 1.218 & 1.011 & 7,449 & 1.061 & 0.909 & $6.69^{* * * *}$ & $9.68^{* * *}$ \\
\hline$R N D_{t}$ & 739 & 0.017 & 0.005 & 7,449 & 0.013 & 0.004 & $4.88^{* * *}$ & $4.57^{* * *}$ \\
\hline RETVOL $L_{t}$ & 739 & 0.030 & 0.029 & 7,449 & 0.030 & 0.028 & -0.42 & 0.94 \\
\hline$O C 1_{t}$ & 739 & 1.000 & 1.000 & 7,449 & 0.000 & 0.000 & $96.19^{* * *}$ & $90.48^{* * *}$ \\
\hline$O C 2_{t}$ & 739 & 0.660 & 1.000 & 7,449 & 0.022 & 0.000 & $82.92^{* * *}$ & $61.13^{* * *}$ \\
\hline$O C 3_{t}$ & 739 & 0.361 & 0.000 & 7,449 & 0.007 & 0.000 & $55.34^{* * *}$ & $47.21^{* * *}$ \\
\hline$S I Z E_{t}$ & 739 & 27.043 & 26.798 & 7,449 & 26.483 & 26.240 & $9.65^{* * * *}$ & $10.25^{* * *}$ \\
\hline PROFIT $_{t}$ & 739 & 0.064 & 0.059 & 7,449 & 0.035 & 0.037 & $10.88^{* * *}$ & $13.48^{* * *}$ \\
\hline$L E V_{t}$ & 739 & 0.530 & 0.538 & 7,449 & 0.433 & 0.429 & $12.41^{* * *}$ & $13.69^{* * *}$ \\
\hline$M B_{t}$ & 739 & 1.551 & 1.131 & 7,449 & 1.128 & 0.771 & $9.04^{* * *}$ & $11.66^{* * *}$ \\
\hline$S G_{t}$ & 739 & 0.151 & 0.110 & 7,449 & 0.066 & 0.042 & $6.82^{* * *}$ & $11.77^{* * *}$ \\
\hline$F O R_{t}$ & 739 & 0.114 & 0.055 & 7,449 & 0.098 & 0.032 & $2.99^{* * *}$ & $6.39^{* * *}$ \\
\hline$O W N_{t}$ & 731 & 0.414 & 0.405 & 7,355 & 0.420 & 0.419 & -0.97 & -1.06 \\
\hline$C F_{t}$ & 739 & 0.058 & 0.060 & 7,449 & 0.046 & 0.045 & $3.39^{* * * *}$ & $4.54^{* * *}$ \\
\hline$F A G E_{t}$ & 739 & 3.401 & 3.611 & 7,449 & 3.465 & 3.638 & $-2.47^{* *}$ & $-2.15^{* *}$ \\
\hline$Q_{t}$ & 739 & 1.231 & 1.047 & 7,449 & 1.027 & 0.886 & $8.92^{* * *}$ & $12.45^{* * *}$ \\
\hline$O D_{t}$ & 735 & 0.189 & 0.000 & 7,368 & 0.171 & 0.000 & 1.22 & 1.22 \\
\hline$S D_{t}$ & 675 & 0.603 & 1.000 & 6,667 & 0.491 & 0.000 & $5.54^{* * *}$ & $5.53^{* * *}$ \\
\hline$C D_{t}$ & 739 & 0.348 & 0.000 & 7,449 & 0.228 & 0.000 & $7.28^{* * *}$ & $7.26^{* * *}$ \\
\hline$E D_{t}$ & 739 & 0.490 & 0.000 & 7,449 & 0.502 & 1.000 & -0.61 & -0.61 \\
\hline$L D_{t}$ & 739 & 0.525 & 1.000 & 7,449 & 0.499 & 0.000 & 1.36 & 1.36 \\
\hline$A D_{t}$ & 735 & 0.512 & 1.000 & 7,368 & 0.500 & 1.000 & 0.59 & 0.59 \\
\hline
\end{tabular}

Panel B: $O C 2$ 기준

\begin{tabular}{|c|c|c|c|c|c|c|c|c|}
\hline \multirow{2}{*}{ 변수 } & \multicolumn{3}{|c|}{ 과신 기업 (a) } & \multicolumn{3}{|c|}{ 비 과신 기업 (b) } & \multicolumn{2}{|c|}{ 차이분석 (a-b) } \\
\hline & $\mathrm{N}$ (개) & mean & median & $\mathrm{N}$ (개) & mean & median & $\mathrm{t}$-value & $z^{-}$value \\
\hline$Q_{t+1}$ & 652 & 1.135 & 0.978 & 7,536 & 1.070 & 0.914 & $2.60^{* * *}$ & $6.42^{* * *}$ \\
\hline$R N D_{t}$ & 652 & 0.017 & 0.017 & 7,536 & 0.013 & 0.004 & $4.65^{* * *}$ & $5.49^{* * *}$ \\
\hline RETVOL $_{t}$ & 652 & 0.030 & 0.028 & 7,536 & 0.030 & 0.028 & -1.63 & -0.44 \\
\hline
\end{tabular}

Panel C: $O C 3$ 기준

\begin{tabular}{|c|c|c|c|c|c|c|c|c|}
\hline \multirow{2}{*}{ 변수 } & \multicolumn{3}{|c|}{ 과신 기업 (a) } & \multicolumn{3}{|c|}{ 비 과신 기업 (b) } & \multicolumn{2}{|c|}{ 차이분석 $(\mathrm{a}-\mathrm{b})$} \\
\hline & $\mathrm{N}$ (개) & mean & median & $\mathrm{N}$ (개) & mean & median & $t^{t-v}$ alue & $Z^{-}$-value \\
\hline$Q_{t+1}$ & 322 & 1.324 & 1.105 & 7,866 & 1.065 & 0.912 & $7.46^{* * * *}$ & $9.81^{* * *}$ \\
\hline$R N D_{t}$ & 322 & 0.022 & 0.010 & 7,866 & 0.013 & 0.004 & $7.74^{* * *}$ & $7.76^{* * *}$ \\
\hline$R E T V O L_{t}$ & 322 & 0.029 & 0.028 & 7,866 & 0.030 & 0.028 & -1.29 & -0.28 \\
\hline
\end{tabular}


Effects of Managerial Overconfidence on the Relationship between Corporate Risk-Taking and Firm Value

〈표 6〉기업의 위험수준과 경영자 과신에 따른 기업가치 차이분석

위험추구 변수 $(R N D, R E T V O L)$ 를 각각 4 개의 분위로 나누고 각 위험추구 수준 내에서 과신 기업과 비 과신 기업의 차년도 기업가치 $(Q)$ 평균(mean) 차이를 비교 검정한 결과이다. ${ }^{* * *},{ }^{* *},{ }^{*}$ 는 각각 $1 \%$, $5 \%, 10 \%$ 유의수준에서 유의함을 의미한다.

Panel A: $O C 1$ 기준

\begin{tabular}{|c|c|c|c|c|c|c|c|}
\hline \multirow{2}{*}{\multicolumn{2}{|c|}{ 위험수준 }} & \multicolumn{2}{|c|}{ 과신 기업 (a) } & \multicolumn{2}{|c|}{ 비 과신 기업 (b) } & \multicolumn{2}{|c|}{ 차이분석 $(\mathrm{a}-\mathrm{b})$} \\
\hline & & $\mathrm{N}$ (개) & mean & $\mathrm{N}$ (개) & mean & 차이 & t-value \\
\hline \multirow[t]{4}{*}{$R N D_{t}$} & 4 (High) & 220 & 1.378 & 1,825 & 1.237 & 0.141 & $2.77^{* * *}$ \\
\hline & 3 & 186 & 1.154 & 1,866 & 1.039 & 0.115 & $2.72^{* * *}$ \\
\hline & 2 & 180 & 1.142 & 1,790 & 0.942 & 0.200 & $5.52^{* * *}$ \\
\hline & 1 (Low) & 153 & 1.159 & 1,968 & 1.027 & 0.132 & $2.43^{* *}$ \\
\hline \multirow[t]{4}{*}{$R E T V O L_{t}$} & 4 (High) & 168 & 1.298 & 1,877 & 1.220 & 0.078 & 1.40 \\
\hline & 3 & 225 & 1.222 & 1,827 & 1.094 & 0.128 & $2.94^{* * *}$ \\
\hline & 2 & 222 & 1.227 & 1,826 & 1.035 & 0.192 & $4.47^{* * *}$ \\
\hline & 1 (Low) & 124 & 1.089 & 1,919 & 0.898 & 0.191 & $4.41^{\text {*** }}$ \\
\hline
\end{tabular}

Panel B: $O C 2$ 기준

\begin{tabular}{|c|c|c|c|c|c|c|c|}
\hline \multirow{2}{*}{\multicolumn{2}{|c|}{ 위험수준 }} & \multicolumn{2}{|c|}{ 과신 기업 (a) } & \multicolumn{2}{|c|}{ 비 과신 기업 (b) } & \multicolumn{2}{|c|}{ 차이분석 $(\mathrm{a}-\mathrm{b})$} \\
\hline & & $\mathrm{N}$ (개) & mean & $\mathrm{N}$ (개) & mean & 차이 & t-value \\
\hline \multirow[t]{4}{*}{$R N D_{t}$} & 4 (High) & 203 & 1.261 & 1,842 & 1.251 & 0.010 & 0.19 \\
\hline & 3 & 169 & 1.162 & 1,883 & 1.039 & 0.123 & $2.80^{* * *}$ \\
\hline & 2 & 156 & 1.031 & 1,814 & 0.954 & 0.077 & $2.00^{* *}$ \\
\hline & 1 (Low) & 124 & 1.021 & 1,997 & 1.038 & -0.017 & -0.27 \\
\hline \multirow[t]{4}{*}{$R E T V O L_{t}$} & 4 (High) & 137 & 1.137 & 1,908 & 1.233 & -0.096 & -1.56 \\
\hline & 3 & 200 & 1.117 & 1,852 & 1.107 & 0.010 & 0.22 \\
\hline & 2 & 194 & 1.179 & 1,854 & 1.043 & 0.136 & $2.99^{* * * *}$ \\
\hline & 1 (Low) & 121 & 1.091 & 1,922 & 0.898 & 0.192 & $4.40^{* * *}$ \\
\hline
\end{tabular}

Panel C: $O C 3$ 기준

\begin{tabular}{|c|c|c|c|c|c|c|c|}
\hline \multirow{2}{*}{\multicolumn{2}{|c|}{ 위험수준 }} & \multicolumn{2}{|c|}{ 과신 기업 (a) } & \multicolumn{2}{|c|}{ 비 과신 기업 (b) } & \multicolumn{2}{|c|}{ 차이분석 (a-b) } \\
\hline & & $\mathrm{N}$ (개) & mean & $\mathrm{N}$ (개) & mean & 차이 & t-value \\
\hline \multirow[t]{4}{*}{$R N D_{t}$} & 4 (High) & 125 & 1.423 & 1,920 & 1.241 & 0.182 & $2.78^{* * *}$ \\
\hline & 3 & 91 & 1.354 & 1,961 & 1.035 & 0.319 & $5.46^{* * *}$ \\
\hline & 2 & 58 & 1.138 & 1,912 & 0.954 & 0.184 & $2.95^{* * *}$ \\
\hline & 1 (Low) & 48 & 1.233 & 2,073 & 1.032 & 0.201 & $2.12^{* *}$ \\
\hline \multirow{4}{*}{$R E T V O L_{t}$} & 4 (High) & 62 & 1.305 & 1,983 & 1.224 & 0.081 & 0.90 \\
\hline & 3 & 105 & 1.309 & 1,947 & 1.097 & 0.212 & $3.42^{* * *}$ \\
\hline & 2 & 104 & 1.316 & 1,944 & 1.042 & 0.274 & $4.52^{* * *}$ \\
\hline & 1 (Low) & 51 & 1.395 & 1,992 & 0.897 & 0.498 & $7.60^{* * * *}$ \\
\hline
\end{tabular}

<표 6>은 기업의 위험추구 수준별로 경영자 과신 여부에 따른 기업가치 차이를 확인한 결과이다. 관련해 연도별로 위험추구 변수 $(R N D, R E T V O L)$ 를 4 분위로 나눈 뒤 경영자 과신 여부에 대해 독립적인 표본을 구성하여 비교하였다. 분석결과 경영자가 과신하는 기업의 경우 비 과신 기업에 비해 차년도(t+1년) 기업가치 $(Q)$ 가 비교적 높음에도 불구하고, 위험추구 수준이 증가할수록 이러한 
한국증권학회지 제 48 권 5 호 (2019)

효과가 축소될 수 있다는 점이 확인된다. 예로 $O C 1$ 변수를 기준으로 한 Panel $\mathrm{A}$ 의 결과를 보면, 주식수익률 변동성 $R E T V O L)$ 관점에서 위험추구 수준이 낮은 하위 그룹(Low 1,2$)$ 의 과신 및 비 과신 두 그룹 간 기업가치 차이가 각각 $0.191,0.192$ 인데 비해, 위험추구 수준의 상위 그룹(High $3,4)$ 간 해당 기업가치 차이는 $0.128,0.178$ 로 그 보다 낮은 것을 볼 수 있다. $O C 2, O C 3$ 를 기준으로 한 Panel B, Panel C에서도 비슷한 패턴을 찾을 수 있다. 특히 위험추구 수준이 가장 높은 그룹(High 4)의 경우가 중간 그룹(High 3, Low 2)에 비해 과신 기업의 기업가치 증분 효과가 작은 것을 볼 수 있다. 연구개발투자 $(R N D)$ 수준을 기준으로 한 차이분석결과에서는 주식수익률 변동성 (RETVOL) 변수의 경우보다 위와 같은 기업가치 차이 패턴이 뚜렷하지 않다. 그러나 위험추구 수준이 가장 높은 그룹(High 4)에서 과신 여부에 따른 기업가치 증분이 중간 그룹(High 3 또는 Low 2)의 것보다 낮다는 점에서, 역시 경영자가 과신하는 경우 기업의 위험추구 수준 증가가 기업가치 제고 효과를 축소시킬 수 있다고 추론해 볼 수 있다.

\section{3 회귀분석결과}

\subsection{1 경영자 과신-위험추구, 경영자 과신-기업가치 관계 사전 분석}

본 소절에서는 가설 1 을 검증하기에 앞서 경영자 과신이 기업의 위험추구에 영향을 미치는 한편 기업가치를 직접 설명하지 않음을 확인함으로써 가설 1 의 관점으로 검증할 필요성을 살핀다. 추가로 이러한 관계로부터 본 연구에서 사용된 과신 변수가 적어도 대리인 문제를 대변하는 변수가 아님을 확인한다.

$<$ 표 7>의 Panel A는 경영자 과신이 기업의 위험추구와 연관성이 있는지 확인한 검증이다. 전반적으로 경영자 과신 더미 $(O C 1, O C 2, O C 3)$ 의 계수가 기업의 위험추구 변수 $(R N D$, $R E T V O L)$ 에 양(+)의 유의적은 값을 보이고 있어, 선행연구의 관점과 유사하게 경영자가 과신하는 경우 기업의 위험추구는 증가함을 확인하였다(Goel and Thakor, 2008; Gervais et al., 2011; Hirshleifer et al., 2012; Baker and Wurgler, 2013). 반면 <표 7>의 Panel B는 경영자 과신이 기업가치를 직접적으로 설명하는지 분석한 결과인데, 모형(1) 모형(9)에서와 같이 경영자 과신 더미 $(O C 1, O C 2, O C 3)$ 의 계수는 모두 유의하지 않았다. <표 6>의 차이분석에서 경영자가 과신하는 그룹에서 기업가치가 보다 높게 나타났지만, <표 7>의 Panel B와 같이 다른 기업 특성을 통제한 이후 경영자 과신은 기업가치를 직접 설명하지 않았다. 이는 비교적 짧은 기간을 대상으로 경영자 과신이 기업성과에 부정적이라고 제시한 국내 Park et al.(2013)의 연구 결과와 차이가 있다. 결국 <표 $7>$ 의 두 분석을 통해 경영자 과신의 효과는 위험추구와 기업가치 간의 관계에서 살펴볼 필요성을 재확인하였다.

추가로 Panel B의 변수 $O C 1, O C 2, O C 3$ 의 계수들이 유의적이지 않다는 것은 적어도 이들 변수가 대리인 문제를 설명하지 않는다는 주장을 간접적으로 뒷받침한다.16) 경영자의 대리인 문제는 이론 및 다수의 실증연구를 통해 확인된 바 기업가치 하락으로 귀결되지만, 경영자의 과신은 비합리적인 의사결정을 유도하더라도 반드시 기업가치를 감소시키는 것이 아니기 때문이다.

16) 본 연구는 과신 변수 추정 시 표면적으로 대리인 문제의 결과와도 일부 관련성이 있는 변수들 즉, 투자, 부채, 낙관적인 이익전망 변수를 사용하고 있지만, 대리인 문제나 파산위험 등 과신으로 보기 어려운 상황을 변수 추정 시 제외하고 있다. 
Effects of Managerial Overconfidence on the Relationship between Corporate Risk-Taking and Firm Value

〈표 7〉 경영자 과신-위험추구, 경영자 과신-기업가치 관계(사전 분석)

경영자 과신 여부 $(O C 1, O C 2, O C 3)$ 가 각각 위험추구 $(R N D, R E T V O L)$ 와 기업가치 $(\mathrm{Q})$ 에 직접적인 영향을 미치는지 확인한 결과이다. Panel $\mathrm{A}$, Panel $\mathrm{B}$ 의 종속변수는 각각 $\mathrm{t}$ 년도 $R N D, R E T V O L$ 와 $\mathrm{t}+1$ 년도의 $Q$ 이며, 주 설명변수는 t년도 경영자 과신 기업 더미(OC1, OC2,OC3)이다(<표 1> 참고). SIZE는 기업규모, PROFIT은 영업이익/매출액, $L E V$ 는 총부채/총자산, $S G$ 는 매출액성장률, $F O R$ 은 외국인 지분율, $O W N$ 은 내부지분율, $C F$ 는 영업현금흐름/총자산, $F A G E$ 는 기업업력, $M B$ 는 시가-장부가비율 이다. Panel A의 $\triangle R N D, \triangle R E T V O L$ 는 위험추구 변수의 추세를 고려하기 위한 각각 전기대비 증감율 변수이다. 괄호 안의 값은 White 방법에 의한 강건한 표준 오차(robust standard error)를 의미하며, ***, ** *는 각각 $1 \%, 5 \%, 10 \%$ 유의수준에서 유의함을 의미한다.

Panel A: 경영자 과신과 위험추구 관계

\begin{tabular}{|c|c|c|c|c|c|c|}
\hline & \multicolumn{3}{|c|}{$R N D_{t}$} & \multicolumn{3}{|c|}{$R E T V O L_{t}$} \\
\hline & (1) & (2) & (3) & (4) & (5) & (6) \\
\hline \multirow[t]{2}{*}{ 상수항 } & 0.267 & 0.273 & 0.290 & $6.693^{* * *}$ & $6.688^{* * *}$ & $6.684^{* * *}$ \\
\hline & (0.499) & $(0.499)$ & (0.498) & $(0.192)$ & $(0.192)$ & $(0.192)$ \\
\hline \multirow[t]{2}{*}{$O C 1_{t}$} & $0.245^{* * *}$ & & & $0.200^{* * *}$ & & \\
\hline & $(0.080)$ & & & (0.028) & & \\
\hline \multirow[t]{2}{*}{$O C 2_{t}$} & & $0.317^{* * *}$ & & & $0.110^{* *}$ & \\
\hline & & $(0.081)$ & & & $(0.030)$ & \\
\hline \multirow{2}{*}{$O C 3_{t}$} & & & $0.524^{* * *}$ & & & $0.310^{* * * *}$ \\
\hline & & & (0.133) & & & $(0.040)$ \\
\hline \multirow[t]{2}{*}{$S I Z E_{t}$} & 0.009 & 0.009 & 0.009 & $-0.163^{* * *}$ & $-0.163^{* * *}$ & $-0.163^{* * *}$ \\
\hline & (0.019) & $(0.019)$ & (0.019) & $(0.007)$ & $(0.007)$ & (0.007) \\
\hline \multirow[t]{2}{*}{ PROFIT $_{t}$} & $1.056^{* *}$ & $0.995^{* *}$ & $1.052^{* *}$ & $-2.435^{* * *}$ & $-2.426^{* * *}$ & $-2.424^{* * * *}$ \\
\hline & $(0.451)$ & $(0.450)$ & (0.449) & (0.183) & (0.183) & $(0.182)$ \\
\hline \multirow{2}{*}{$L E V_{t}$} & -0.044 & -0.057 & -0.037 & $1.016^{* * *}$ & $1.019^{* * * *}$ & $1.019^{* * *}$ \\
\hline & $(0.114)$ & $(0.115)$ & (0.114) & $(0.051)$ & $(0.051)$ & $(0.050)$ \\
\hline \multirow[t]{2}{*}{$S G_{t}$} & $0.190^{* *}$ & $0.188^{* *}$ & $0.184^{* *}$ & $0.166^{* * *}$ & $0.166^{* * *}$ & $0.167^{* * *}$ \\
\hline & $(0.093)$ & $(0.092)$ & $(0.092)$ & $(0.037)$ & $(0.037)$ & $(0.037)$ \\
\hline \multirow[t]{2}{*}{$F O R_{t}$} & $1.055^{* * *}$ & $1.040^{* * *}$ & $1.034^{* * *}$ & $-0.659^{* * *}$ & $-0.659^{* * *}$ & $-0.659^{* * *}$ \\
\hline & $(0.207)$ & $(0.207)$ & $(0.207)$ & $(0.075)$ & $(0.075)$ & $(0.075)$ \\
\hline \multirow[t]{2}{*}{$O W N_{t}$} & -0.206 & -0.204 & -0.201 & $-0.803^{* * *}$ & $-0.803^{* * *}$ & $-0.803^{* * *}$ \\
\hline & $(0.141)$ & $(0.141)$ & $(0.141)$ & $(0.060)$ & $(0.060)$ & $(0.060)$ \\
\hline \multirow[t]{2}{*}{$C F_{t}$} & $0.777^{* *}$ & $0.842^{* *}$ & $0.762^{* *}$ & $-0.693^{* * *}$ & $-0.697^{* * *}$ & $-0.694^{* * *}$ \\
\hline & $(0.366)$ & $(0.364)$ & (0.364) & (0.135) & (0.135) & $(0.134)$ \\
\hline \multirow{2}{*}{$M B_{t}$} & $0.254^{* * *}$ & $0.258^{* * *}$ & $0.251^{* * *}$ & $0.200^{* * *}$ & $0.200^{* * *}$ & $0.201^{* * * *}$ \\
\hline & $(0.029)$ & $(0.029)$ & (0.029) & (0.009) & (0.009) & $(0.009)$ \\
\hline \multirow[t]{2}{*}{$\triangle R N D_{t}$} & $9.017^{* *}$ & $9.076^{* *}$ & $9.101^{* *}$ & & & \\
\hline & (4.134) & (4.144) & (4.156) & & & \\
\hline \multirow[t]{2}{*}{$\triangle R E T V O L_{t}$} & & & & $44.609^{* * *}$ & $44.612^{* * *}$ & $44.602^{* * *}$ \\
\hline & & & & (1.201) & (1.201) & $(1.201)$ \\
\hline 산업, 연도더미 & 포함 & 포함 & 포함 & 포함 & 포함 & 포함 \\
\hline No. of Obs. & 7,799 & 7,799 & 7,799 & 7,799 & 7,799 & 7,799 \\
\hline F-Value & $83.269^{* * *}$ & $83.274^{* * * *}$ & $83.315^{* * *}$ & $272.999^{* * *}$ & $273.043^{* * *}$ & $273.240^{* * *}$ \\
\hline Adj. $R^{2}$ & 0.2816 & 0.2821 & 0.2829 & 0.5752 & 0.5752 & 0.5752 \\
\hline
\end{tabular}


한국증권학회지 제 48 권 5호 (2019)

〈표 7〉경영자 과신-위험추구, 경영자 과신-기업가치 관계(사전 분석)(계속)

Panel B: 경영자 과신과 기업가치의 관계

\begin{tabular}{|c|c|c|c|c|c|c|c|c|c|}
\hline & \multicolumn{9}{|c|}{ Tobin's $Q_{t+1}$} \\
\hline & (1) & (2) & (3) & (4) & (5) & (6) & (7) & (8) & (9) \\
\hline \multirow{2}{*}{ 상수항 } & $1.468^{* * * *}$ & $1.464^{* * *}$ & $1.466^{* * *}$ & $1.358^{* * *}$ & $1.353^{* * *}$ & $1.355^{* * *}$ & $1.324^{* * * *}$ & $1.320^{* * * *}$ & $1.322^{* * *}$ \\
\hline & $(0.119)$ & (0.119) & (0.119) & $(0.120)$ & $(0.120)$ & $(0.120)$ & $(0.120)$ & $(0.120)$ & $(0.120)$ \\
\hline \multirow[t]{2}{*}{$O C 1_{t}$} & 0.012 & & & 0.017 & & & 0.012 & & \\
\hline & $(0.018)$ & & & $(0.018)$ & & & $(0.018)$ & & \\
\hline \multirow[t]{2}{*}{$O C 2_{t}$} & & 0.001 & & & 0.007 & & & 0.001 & \\
\hline & & $(0.015)$ & & & $(0.015)$ & & & (0.015) & \\
\hline \multirow[t]{2}{*}{$O C 3_{t}$} & & & 0.009 & & & 0.019 & & & 0.011 \\
\hline & & & $(0.027)$ & & & $(0.027)$ & & & $(0.027)$ \\
\hline \multirow[t]{2}{*}{$R N D_{t}$} & $1.786^{* * *}$ & $1.792^{* * * *}$ & $1.788^{* * *}$ & & & & $1.842^{* * * *}$ & $1.848^{* * * *}$ & $1.843^{* * *}$ \\
\hline & $(0.342)$ & $(0.342)$ & $(0.342)$ & & & & (0.343) & (0.343) & $(0.343)$ \\
\hline \multirow[t]{2}{*}{$R E T V O L_{t}$} & & & & 1.929 & 1.927 & $1.932^{* * *}$ & $2.133^{* * *}$ & $2.131^{* * *}$ & $2.134^{* * *}$ \\
\hline & & & & $(0.566)$ & $(0.566)$ & $(0.566)$ & $(0.566)$ & $(0.566)$ & $(0.566)$ \\
\hline \multirow[t]{2}{*}{$S I Z E_{t}$} & $-0.018^{* * * *}$ & $-0.018^{* * *}$ & $-0.018^{* * *}$ & -0.015 & -0.015 & $-0.015^{* * *}$ & $-0.015^{* * *}$ & $-0.015^{* * *}$ & $-0.015^{* * *}$ \\
\hline & $(0.004)$ & $(0.004)$ & $(0.004)$ & $(0.004)$ & $(0.004)$ & $(0.004)$ & $(0.004)$ & $(0.004)$ & $(0.004)$ \\
\hline \multirow[t]{2}{*}{ PROFIT $_{t}$} & 0.065 & 0.071 & 0.070 & 0.143 & 0.149 & 0.148 & 0.125 & 0.132 & 0.129 \\
\hline & (0.129) & (0.129) & (0.128) & (0.129) & $(0.130)$ & (0.129) & (0.129) & (0.129) & (0.128) \\
\hline \multirow[t]{2}{*}{$L E V_{t}$} & -0.011 & -0.008 & -0.009 & -0.033 & -0.030 & -0.031 & -0.032 & -0.030 & -0.031 \\
\hline & $(0.032)$ & $(0.032)$ & $(0.032)$ & $(0.034)$ & $(0.034)$ & $(0.033)$ & $(0.034)$ & $(0.034)$ & $(0.033)$ \\
\hline \multirow[t]{2}{*}{$F A G E_{t}$} & $-0.034^{* * *}$ & $-0.034^{* * *}$ & $-0.034^{* * * *}$ & -0.039 & -0.039 & $-0.039^{* * * *}$ & $-0.034^{* * * *}$ & $-0.034^{* * *}$ & $-0.034^{* * *}$ \\
\hline & $(0.008)$ & (0.008) & $(0.008)$ & $(0.008)$ & (0.008) & (0.008) & $(0.008)$ & $(0.008)$ & $(0.008)$ \\
\hline \multirow[t]{2}{*}{$S G_{t}$} & 0.011 & 0.012 & 0.011 & 0.013 & 0.013 & 0.013 & 0.009 & 0.009 & 0.009 \\
\hline & $(0.020)$ & $(0.020)$ & $(0.020)$ & $(0.020)$ & $(0.020)$ & $(0.020)$ & $(0.020)$ & $(0.020)$ & $(0.020)$ \\
\hline \multirow[t]{2}{*}{$F O R_{t}$} & $0.310^{* * * *}$ & $0.309^{* * * *}$ & $0.309^{* * * *}$ & 0.343 & 0.342 & $0.342^{* * *}$ & $0.325^{* * *}$ & $0.324^{* * *}$ & $0.324^{* * *}$ \\
\hline & $(0.045)$ & $(0.045)$ & $(0.045)$ & $(0.045)$ & $(0.045)$ & $(0.045)$ & $(0.045)$ & $(0.045)$ & $(0.045)$ \\
\hline \multirow[t]{2}{*}{$O W N_{t}$} & $-0.126^{* * *}$ & $-0.126^{* * *}$ & $-0.126^{* * *}$ & $-0.117^{* * *}$ & $-0.117^{* * *}$ & $-0.117^{* * *}$ & $-0.110^{* * *}$ & $-0.110^{* * *}$ & $-0.110^{* * *}$ \\
\hline & $(0.036)$ & $(0.036)$ & $(0.036)$ & $(0.036)$ & $(0.036)$ & $(0.036)$ & $(0.036)$ & $(0.036)$ & $(0.036)$ \\
\hline \multirow[t]{2}{*}{$C F_{t}$} & $0.214^{* * * *}$ & $0.213^{* *}$ & $0.212^{* * *}$ & $0.234^{* * *}$ & $0.234^{* * *}$ & $0.233^{* * *}$ & $0.227^{* * *}$ & $0.226^{* * *}$ & $0.226^{* * * *}$ \\
\hline & $(0.082)$ & $(0.083)$ & $(0.082)$ & $(0.082)$ & $(0.082)$ & $(0.082)$ & $(0.082)$ & $(0.083)$ & $(0.082)$ \\
\hline \multirow[t]{2}{*}{$Q_{t}$} & $0.328^{* * * *}$ & $0.328^{* * *}$ & $0.328^{* * * *}$ & $0.328^{* * *}$ & $0.328^{* * *}$ & $0.328^{* * *}$ & $0.323^{* * *}$ & $0.323^{* * *}$ & $0.323^{* * *}$ \\
\hline & $(0.012)$ & $(0.012)$ & $(0.012)$ & $(0.012)$ & $(0.012)$ & $(0.012)$ & $(0.012)$ & $(0.012)$ & $(0.012)$ \\
\hline 산업, 연도더미 & 포함 & 포함 & 포함 & 포함 & 포함 & 포함 & 포함 & 포함 & 포함 \\
\hline No. of Obs. & 8,086 & 8,086 & 8,086 & 8,086 & 8,086 & 8,086 & 8,086 & 8,086 & 8,086 \\
\hline $\mathrm{F}$-Value & $90.516^{* * *}$ & $90.731^{* * *}$ & $90.385^{* * * *}$ & $93.415^{* * *}$ & $93.708^{* * * *}$ & $93.316^{* * *}$ & $92.896^{* * * *}$ & $93.169^{* * * *}$ & $92.818^{* * * *}$ \\
\hline Adj. $\mathrm{R}^{2}$ & 0.5390 & 0.5390 & 0.5370 & 0.5370 & 0.5370 & 0.5398 & 0.5398 & 0.5398 & 0.5398 \\
\hline
\end{tabular}

\subsection{2 위험추구-기업가치 관계에서 경영자 과신의 영향}

$<$ 표 8>은 위험추구와 기업가치의 관계에서 경영자 과신의 효과를 검증한 결과이다. 모형 (1), (5)는 경영자 과신을 고려하지 않고, 각각 위험추구 $R N D, R E T V O L)$ 변수가 기업가치에 미치는 효과를 확인한 것이다. 분석결과 기업의 위험추구는 위험부담에 대한 대가로 수익을 창출해 궁극적으로 기업가치를 제고시키고 있었다.

모형 (2), (3), (4)는 위험추구 대용치로 연구개발투자 $(R N D)$ 를, 모형 (6), (7), (8)은 수익률 변동성 $(R E T V O L)$ 을 각각 이용해 경영자 과신 더미 $(O C 1, O C 2, O C 3)$ 와 교차항을 구성하고 
Effects of Managerial Overconfidence on the Relationship between Corporate Risk-Taking and Firm Value

가설 1 을 검증한 결과이다. 분석결과 교차항 $R N D \times O C 1, R N D \times O C 2, R N D \times O C 3, R E T V O L \times$ $O C 1, R E T V O L \times O C 2, R E T V O L \times O C 3$ 의 계수는 모든 모형에서 유의적은 음 $(-)$ 의 값을 보이고 있다. 모형 (1), (5)의 결과와 비교해 해석하면, 기업의 위험추구는 기업가치를 증가시키지만 경영자가 과신하는 경우 기업의 위험추구는 적정 수준에 이르지 못하고 결국 기업가치를 하락시킨다고 볼 수 있다. 그런데 앞서 <표 $5>$ 차이분석으로부터 적어도 본 연구의 표본의 경우 경영자가 과신하는 기업은 재무제약으로 인한 과소투자(Malmender and Tate, 2005)나 위험을 회피하는 문제가 심각하지 않을 것으로 판단된다. 따라서 <표 8>의 경영자 과신으로 인한 기업가치 하락은 과신 성향의 경영자가 위험을 과도하게 추구하거나 현재 기업에 부적절한 위험추구 의사결정을 하는 문제에서 비롯되었다고 해석해 볼 수 있다. 이러한 결과는 경영자 과신이 위험추구 차원에서 기업에 부정적으로 작용한다는 점에서, 인수합병, 실물투자, 위험관리 등의 차원에서 과신하는 경영자의 위험추구가 기업가치를 하락시킨다는 선행연구들의 관점과 맥락을 같이 한다(Hayward and Hambrick, 1997; Heaton, 2002; Malmendier and Tate, 2005; Goel and Thakor, 2008; Malmendier and Tate, 2008; Gervais et al., 2011; Chen et al., 2014; Adam et al., 2015; Park et al., 2013). 또한 이는 국내 경영자의 대리인 문제 이외에도 그들의 과신이 위험추구와 기업가치의 관계에 부정적일 수 있다는 결과이기도 하다.

통제 변수의 경우 대부분 모형에서 부호와 유의성이 일관되게 추정되었다. 외국인 지분율 $(F O R)$ 이 높을수록, 현금흐름 $(C F)$ 이 많을수록, 과거 기업가치가 높을수록 $(Q)$ 미래 기업가치가 높았다. 반면 기업규모(SIZE)가 크고 기업 업력 $(F A G E)$ 과 내부지분율 $(O W N)$ 이 높은 기업일 수록 미래 기업가치가 하락하는 것으로 나타났다.

〈표 8〉 위험추구-기업가치 관계에서 경영자 과신의 영향

경영자 과신 여부 $(O C 1, O C 2, O C 3)$ 가 위험추구-기업가치의 관계에 영향을 미치는지 분석한 결과이다. 종속변수는 $\mathrm{t}+1$ 년도의 $Q$ 이며, 주 설명변수로는 $\mathrm{t}$ 년도 연구개발투자비율 $(R N D)$, 주식수익률 변동성 $(R E T V O L)$, 과신 기업 더미 $(O C 1, O C 2, O C 3)$ 이다. SIZE는 기업규모, PROFIT은 영업이익/매출액, $L E V$ 는 총부채/ 총자산, $S G$ 는 매출액성장률, $F O R$ 은 외국인 지분율, $O W N$ 은 내부지분율, $C F$ 는 영업현금흐름/총자산이다. 괄호안의 값은 강건한 표준 오차(robust standard error)를 의미하며, ${ }^{*},{ }^{* *},{ }^{* * *}$ 는 각각 $10 \%, 5 \%$, 그리고 $1 \%$ 유의수준에서 유의적임을 나타낸다.

\begin{tabular}{|c|c|c|c|c|c|c|c|c|}
\hline & \multicolumn{8}{|c|}{ Tobin's $Q_{t+1}$} \\
\hline & (1) & (2) & (3) & (4) & (5) & (6) & (7) & (8) \\
\hline 상수항 & $\begin{array}{l}1.463^{* * *} \\
(0.119)\end{array}$ & $\begin{array}{c}1.472^{* * *} \\
(0.119)\end{array}$ & $\begin{array}{c}1.468^{* * * *} \\
(0.119)\end{array}$ & $\begin{array}{c}1.469^{* * * *} \\
(0.119)\end{array}$ & $\begin{array}{c}1.351^{* * *} \\
(0.120)\end{array}$ & $\begin{array}{l}1.338^{* * * *} \\
(0.120)\end{array}$ & $\begin{array}{c}1.344^{* * *} \\
(0.120)\end{array}$ & $\begin{array}{l}1.343^{* * * *} \\
(0.121)\end{array}$ \\
\hline$R N D_{t}$ & $\begin{array}{c}1.793^{* * *} \\
(0.341)\end{array}$ & $\begin{array}{c}2.022^{* * *} \\
(0.361)\end{array}$ & $\begin{array}{c}1.975^{* * *} \\
(0.363)\end{array}$ & $\begin{array}{c}2.010^{* * * *} \\
(0.353)\end{array}$ & & & & \\
\hline$R N D_{t} \times O C 1_{t}$ & & $\begin{array}{l}-1.880^{* *} \\
(0.816)\end{array}$ & & & & & & \\
\hline$R N D_{t} \times O C Z_{t}$ & & & $\begin{array}{l}-1.766^{* *} \\
(0.689)\end{array}$ & & & & & \\
\hline$R N D_{t} \times O C 3_{t}$ & & & & $\begin{array}{l}-3.174^{* * *} \\
(0.982)\end{array}$ & & & & \\
\hline
\end{tabular}


한국증권학회지 제48권 5호 (2019)

〈표 8〉 위험추구-기업가치 관계에서 경영자 과신의 영향(계속)

\begin{tabular}{|c|c|c|c|c|c|c|c|c|}
\hline & \multicolumn{8}{|c|}{ Tobin's $Q_{t+1}$} \\
\hline & (1) & (2) & (3) & (4) & (5) & (6) & (7) & (8) \\
\hline $\mathrm{RETVOL}_{t}$ & & & & & $\begin{array}{c}1.926^{* * *} \\
(0.566)\end{array}$ & $\begin{array}{c}2.305^{* * *} \\
(0.592)\end{array}$ & $\begin{array}{c}2.139^{* * * *} \\
(0.589)\end{array}$ & $\begin{array}{l}2.111^{* * *} \\
(0.574)\end{array}$ \\
\hline$R E T V O L_{t} \times O C 1_{t}$ & & & & & & $\begin{array}{l}-4.954^{* * *} \\
(1.639)\end{array}$ & & \\
\hline$R E T V O L_{t} \times O C 2_{t}$ & & & & & & & $\begin{array}{l}-3.163^{* *} \\
(1.483)\end{array}$ & \\
\hline$R E T V O L_{t} \times O C 3_{t}$ & & & & & & & & $\begin{array}{l}-6.223^{* *} \\
(2.711)\end{array}$ \\
\hline$O C 1_{t}$ & & $\begin{array}{c}0.043^{*} \\
(0.022)\end{array}$ & & & & $\begin{array}{c}0.166^{* * *} \\
(0.051)\end{array}$ & & \\
\hline$O C 2_{t}$ & & & $\begin{array}{c}0.030^{*} \\
(0.017)\end{array}$ & & & & $\begin{array}{c}0.100^{* *} \\
(0.045)\end{array}$ & \\
\hline$O C 3_{t}$ & & & & $\begin{array}{c}0.077^{* * *} \\
(0.034)\end{array}$ & & & & $\begin{array}{c}0.202^{* *} \\
(0.084)\end{array}$ \\
\hline$S I Z E_{t}$ & $\begin{array}{l}-0.018^{* * * *} \\
(0.004)\end{array}$ & $\begin{array}{l}-0.019^{* * * *} \\
(0.004)\end{array}$ & $\begin{array}{l}-0.019^{* * * *} \\
(0.004)\end{array}$ & $\begin{array}{l}-0.019^{* * *} \\
(0.004)\end{array}$ & $\begin{array}{l}-0.015^{* * *} \\
(0.004)\end{array}$ & $\begin{array}{l}-0.015^{* * *} \\
(0.004)\end{array}$ & $\begin{array}{l}-0.015^{* * *} \\
(0.004)\end{array}$ & $\begin{array}{l}-0.015^{* * * *} \\
(0.004)\end{array}$ \\
\hline PROFIT $_{t}$ & $\begin{array}{r}0.072 \\
(0.128)\end{array}$ & $\begin{array}{r}0.069 \\
(0.129)\end{array}$ & $\begin{array}{r}0.076 \\
(0.129)\end{array}$ & $\begin{array}{r}0.074 \\
(0.128)\end{array}$ & $\begin{array}{r}0.153 \\
(0.128)\end{array}$ & $\begin{array}{r}0.156 \\
(0.129)\end{array}$ & $\begin{array}{r}0.160 \\
(0.130)\end{array}$ & $\begin{array}{r}0.152 \\
(0.129)\end{array}$ \\
\hline$L E V_{t}$ & $\begin{array}{l}-0.008 \\
(0.032)\end{array}$ & $\begin{array}{l}-0.012 \\
(0.032)\end{array}$ & $\begin{array}{l}-0.010 \\
(0.032)\end{array}$ & $\begin{array}{l}-0.010 \\
(0.032)\end{array}$ & $\begin{array}{l}-0.029 \\
(0.033)\end{array}$ & $\begin{array}{l}-0.036 \\
(0.034)\end{array}$ & $\begin{array}{l}-0.032 \\
(0.034)\end{array}$ & $\begin{array}{l}-0.032 \\
(0.033)\end{array}$ \\
\hline$F A G E_{t}$ & $\begin{array}{l}-0.034^{* * *} \\
(0.008)\end{array}$ & $\begin{array}{l}-0.034^{* * * *} \\
(0.008)\end{array}$ & $\begin{array}{l}-0.034^{* * *} \\
(0.008)\end{array}$ & $\begin{array}{l}-0.034^{* * * *} \\
(0.008)\end{array}$ & $\begin{array}{l}-0.038^{* * *} \\
(0.008)\end{array}$ & $\begin{array}{l}-0.038^{* * *} \\
(0.008)\end{array}$ & $\begin{array}{l}-0.038^{* * *} \\
(0.008)\end{array}$ & $\begin{array}{l}-0.038^{* * * *} \\
(0.008)\end{array}$ \\
\hline$S G_{t}$ & $\begin{array}{r}0.012 \\
(0.020)\end{array}$ & $\begin{array}{r}0.011 \\
(0.020)\end{array}$ & $\begin{array}{r}0.012 \\
(0.020)\end{array}$ & $\begin{array}{r}0.011 \\
(0.020)\end{array}$ & $\begin{array}{r}0.013 \\
(0.020)\end{array}$ & $\begin{array}{r}0.014 \\
(0.020)\end{array}$ & $\begin{array}{r}0.014 \\
(0.020)\end{array}$ & $\begin{array}{r}0.014 \\
(0.020)\end{array}$ \\
\hline$F O R_{t}$ & $\begin{array}{c}0.309^{* * *} \\
(0.045)\end{array}$ & $\begin{array}{c}0.308^{* * *} \\
(0.045)\end{array}$ & $\begin{array}{c}0.307^{* * *} \\
(0.045)\end{array}$ & $\begin{array}{c}0.305^{* * *} \\
(0.045)\end{array}$ & $\begin{array}{c}0.342^{* * *} \\
(0.045)\end{array}$ & $\begin{array}{c}0.341^{* * *} \\
(0.045)\end{array}$ & $\begin{array}{c}0.341^{\text {**** }} \\
(0.045)\end{array}$ & $\begin{array}{c}0.338^{* * *} \\
(0.045)\end{array}$ \\
\hline$O W N_{t}$ & $\begin{array}{l}-0.126^{* * *} \\
(0.036)\end{array}$ & $\begin{array}{l}-0.127^{* * *} \\
(0.036)\end{array}$ & $\begin{array}{l}-0.128^{* * *} \\
(0.036)\end{array}$ & $\begin{array}{l}-0.128^{* * *} \\
(0.036)\end{array}$ & $\begin{array}{l}-0.117^{* * *} \\
(0.036)\end{array}$ & $\begin{array}{l}-0.116^{* * *} \\
(0.036)\end{array}$ & $\begin{array}{l}-0.116^{* * *} \\
(0.036)\end{array}$ & $\begin{array}{l}-0.116^{\text {**** }} \\
(0.036)\end{array}$ \\
\hline$C F_{t}$ & $\begin{array}{c}0.212^{* * *} \\
(0.082)\end{array}$ & $\begin{array}{c}0.211^{* *} \\
(0.082)\end{array}$ & $\begin{array}{c}0.209^{* * *} \\
(0.083)\end{array}$ & $\begin{array}{c}0.209^{* *} \\
(0.082)\end{array}$ & $\begin{array}{c}0.232^{* * *} \\
(0.082)\end{array}$ & $\begin{array}{c}0.236^{* * *} \\
(0.082)\end{array}$ & $\begin{array}{c}0.232^{* * *} \\
(0.082)\end{array}$ & $\begin{array}{c}0.236^{* * *} \\
(0.082)\end{array}$ \\
\hline$Q_{t}$ & $\begin{array}{c}0.328^{* * * *} \\
(0.012)\end{array}$ & $\begin{array}{c}0.328^{* * * *} \\
(0.012)\end{array}$ & $\begin{array}{c}0.328^{* * * *} \\
(0.012)\end{array}$ & $\begin{array}{c}0.328^{* * * *} \\
(0.012)\end{array}$ & $\begin{array}{c}0.328^{* * *} \\
(0.012)\end{array}$ & $\begin{array}{c}0.328^{* * * *} \\
(0.012)\end{array}$ & $\begin{array}{c}0.328^{* * *} \\
(0.012)\end{array}$ & $\begin{array}{c}0.327^{* * *} \\
(0.012)\end{array}$ \\
\hline 연도, 산업 더미 & 포함 & 포함 & 포함 & 포함 & 포함 & 포함 & 포함 & 포함 \\
\hline $\begin{array}{l}\text { No. of Obs. } \\
\text { F-Value } \\
\text { Adj. } R^{2}\end{array}$ & $\begin{array}{c}8,086 \\
94.978^{* * *} \\
0.5390\end{array}$ & $\begin{array}{c}8,086 \\
88.164^{* * * *} \\
0.5394\end{array}$ & $\begin{array}{c}8,086 \\
88.663^{* * * *} \\
0.5392\end{array}$ & $\begin{array}{c}8,086 \\
88.673^{* * *} \\
0.5396\end{array}$ & $\begin{array}{c}8,086 \\
95.929^{* * *} \\
0.5370\end{array}$ & $\begin{array}{c}8,086 \\
91.279^{* * *} \\
0.5375\end{array}$ & $\begin{array}{c}8,086 \\
91.482^{* * *} \\
0.5371\end{array}$ & $\begin{array}{c}8,086 \\
90.953^{* * *} \\
0.5373\end{array}$ \\
\hline
\end{tabular}

\subsection{3 위험추구-기업가치 관계에서 경영자 과신의 조절 기제}

본 소절에서는 과신의 부정적 효과가 확인된 만큼 어떠한 조절 메커니즘이 유효한지를 검증 하는데 초점을 맞춘다. 분석은 식 (2)를 토대로 위험추구변수, 과신변수, 조절변수를 이용해 교차항을 구성하고 해당 조절변수가 과신으로 인한 위험추구의 부정적 효과를 완화시키는지의 관점으로 구성하였다. 
Effects of Managerial Overconfidence on the Relationship between Corporate Risk-Taking and Firm Value

먼저 <표 9>의 Panel A, B는 기업의 내부 지배구조 요인으로 이사회의 경영 감시 역할이 경영자의 과신으로 인한 최적위험추구 실패를 일부 통제할 수 있는지 확인하기 위해 사외이사 초과 선임 여부 더미 $(O D)$ 와 이사회 점수 상위 기업 더미 $(S D)$ 를 이용해 가설 2-1, 가설 2-2를 검증한 결과이다. 분석결과 $R N D \times O C 1 \times O D, R N D \times O C 2 \times O D, R N D \times O C 3 \times O D, R E T V O L \times$ $O C 1 \times O D, R E T V O L \times O C 2 \times O D, R E T V O L \times O C 3 \times O D, R N D \times O C 1 \times S D, R N D \times O C 2 \times S D$, $R N D \times O C 3 \times S D, R E T V O L \times O C 1 \times S D, R E T V O L \times O C 2 \times S D, R E T V O L \times O C 3 \times S D$ 의 회귀 계수는 모두 유의하지 않았다. 따라서 이사회의 경영자 통제 및 이들의 독립적인 역할을 통해 경영자의 과신으로 인한 가치훼손을 줄일 수 있다는 기존 선행연구의 주장(Hayward and Hambrick, 1997; Heaton, 2002; Malmendier and Tate, 2005; Goel and Thakor, 2008; Gervais et al., 2011; Park et al., 2013)이 국내 기업을 대상으로는 재확인되지 않았다. 이는 국내 기업이 법정 요건을 초과해 자발적으로 사외이사를 추가 선임한다 하더라도, 이러한 사외이사 구조가 경영자가 과신으로 범하기 쉬운 독단적 의사결정을 견제하기 어렵다는 것을 의미한다. 더불어 국내의 경우 이사회 구성과 운영이 상대적으로 우수한 기업이라 하더라도 경영자의 과신으로 초래된 위험 선택을 통제하는데 미흡함이 존재함을 의미하는 결과이기도 하다. 따라서 현재까지의 국내 이사회 운영에 관한 평가기준을 고려했을 때, 상대적으로 양호한 이사회의 운영은 기업의 대리인 문제 관점에서 경영자의 기회주의를 통제함으로써 비교적 긍정적인 평가를 얻고 있지만 (Park and Yon, 2009; Cho et al., 2016), 행태기업재무 관점에서 경영자의 과신 행태를 통제하는데 한계가 있음이 확인된다. 특히 과신 관점의 경우 경영자가 일부 충실한 대리인으로 존재할 수 있기 때문에 이사회가 경영자의 의사결정에 오류가 있는지 판가름하기가 쉽지 않거나, 경영자의 과신 가능성을 높이는 그들의 조직 내 파워를 이사회가 적절히 통제하지 못했기 때문으로 생각해볼 수 있다. ${ }^{17)}$

<표 9>의 Panel C는 가설 3 의 검증으로 재벌 소속 여부 $(C D)$ 가 경영자 과신의 부정적 효과를 통제하는지 분석한 결과이다. 분석결과 위험추구변수 $(R N D, R E T V O L)$, 과신변수 $(O C 1, O C 2$, $O C 3)$, 재벌 소속 여부 $(C D)$ 를 이용한 모든 교차항의 계수가 유의하지 않았다. 이는 재벌의 통제가 경영자의 독단적 의사결정과 위험감수 성향을 통제(Park et al., 2013)할 수도 있지만, 재벌 집단의 상호지원 및 위험공유 기회(Bae and Lim, 2003)로 재벌 내 기업 경영자로 하여금 투자 안의 위험을 과소평가하도록 유도해 결국 기업이 적절한 위험추구에 실패할 가능성 또한 상존한다는 점을 의미한다.

<표 9>의 Panel D, E는 시장 불확실 완화와 산업 내 경쟁 축소가 경영자 과신의 부정적 효과를 통제하는 요인인지 검증한 결과이다. 실증분석은 경제정책 불확실 하위 년도 더미 $(E D)$ 와 시장 경쟁 강도 하위 산업 더미 $(L D)$ 를 이용해 각각 분석하였다. 분석결과 <표 $9>$ 의 Panel $\mathrm{D}$ 모형(4)의 교차항 $R E T V O L \times O C 1 \times E D$ 계수를 제외하고 나머지 위험추구변수, 과신변수,

17) Hwang et al.(2018)의 연구는 최고경영자의 조직 내 파워가 그들의 과신 성향을 높이고, 과신으로 초래된 M\&A를 유도한다고 설명하고 있다. 경영자의 조직 내 파워는 그들의 선·해임 뿐 만아니라 보수, 정년, 내부 이사회 구성 등과 관련해 결국 이사회의 역할과 밀접한 연관이 있으므로 본 내용과 같이 해석하였다. 
한국증권학회지 제48권 5호 (2019)

조절변수의 교차항들은 모두 유의하지 않았다. 이는 연구가설에서 설명한 바와 같이 시장불확실 완화와 시장 경쟁 축소의 긍정적 조절 역할 뿐만 아니라, 부정적 조절 역할이 모두 존재하기 때문인 것으로 판단된다. 즉, 시장불확실 완화와 시장 경쟁 축소가 경영자의 재량적 의사결정을 축소시킴으로써 과신의 효과를 약화시킬 수도 있지만(Li and Tang, 2010; Tang et al., 2016), 동시에 이러한 경영환경은 과신하는 경영자에게 우호적인 상황으로 받아들여져 오히려 경영자의 과신 또는 낙관을 심화시킬 수도 있기 때문으로 해석해 볼 수 있다.

한편 <표 9>의 Panel D 모형 (4)에서 $R E T V O L \times O C 1 \times E D$ 의 유의적인 음(-)의 계수로부터 경제정책 불확실이 낮은 시기에 경영자의 과신이 오히려 기업의 위험추구와 기업가치의 관계를 악화시킬 수 있다는 것을 확인하였다. ${ }^{18)}$ 이는 기초통계에서 국내 거시여건이 비교적 경영에 우호적이었던 기간(2004년 2007년)과 글로벌 금융위기 이후 회복기(2010년)에 과신 기업 수가 상대적으로 많았다는 점과 일부연관이 있다. 따라서 과신하는 경영자들은 이러한 경제정책 불확실이 낮은 시기를 경영에 우호적인 상황으로 판단해 위험을 과소평가하고 과도한 위험추구를 감행하고 있다고 판단된다. 이상의 결과를 종합해 볼 때 본 연구에서 검토한 기업 외부 지배구조 요인들은 국내 경영자 과신의 부정적 효과를 통제하는 장치로는 한계가 있다고 판단된다.

<표 9>의 Panel $\mathrm{F}$ 는 경영자의 평균 나이 상위 더미 $(A D)$ 를 고려한 분석이다. 분석결과 모형 (1)의 $R N D \times O C 1 \times A D$ 계수, 모형 (2)의 $R N D \times O C 2 \times A D$ 계수, 모형 (3)의 $R N D \times O C 3$ $\times A D$ 계수, 그리고 모형 (6)의 $R E T V O L \times O C 3 \times A D$ 계수가 각각 $3.195,3.152,4.318,6.617$ 로 유의적인 양 $(+)$ 의 값으로 추정되었다. 따라서 상대적으로 나이가 많은 경영자들이 나이가 적은 경영자들보다 과신으로 인한 기업가치 하락을 덜 유도한다는 것을 알 수 있었다. 이는 Tang et al.(2016)의 주장처럼 경영자의 나이가 많을수록 상당한 직무 도전에 처할 가능성이 낮고, 의사결정에 있어 심리적 편의에 영향을 덜 받아 결국 과신 가능성이 낮아질 뿐만 아니라, 경영자 과신의 부정적 효과가 감소한 것으로 해석해 볼 수 있다.

\subsection{4 강건성 검증}

본 연구는 국내 경영자의 과신 효과를 검증함에 있어 위험추구와 기업가치의 관계에서 분석하고, 과신의 원인 및 결과 변수를 활용해 과신 기업을 판별하며, 분석기간 확대 등을 통해 보다 일반적인 결과를 도출하고 있다. 그럼에도 불구하고 본 연구는 연구결과의 강건성 확보를 위해 주요 변수와 하위 샘플 분석 차원에서 5 가지 추가 분석을 실시했다. 각각의 분석결과는 본 연구의 기존 결과 및 주장을 견지했으며 세부 결과표는 지면관계상 생략한다.19)

먼저, 종속변수를 산업조정 Tobin's Q로 대체하여 분석함으로써 일관된 분석결과가 유도되는지 확인하였다. 해당 변수는 Tobin's Q가 갖는 문제점, 예로 해당 변수가 기업가치를

18) 경제정책 불확실 완화의 효과가 일부 유의한 음(-)의 결과를 보인 것을 역으로 해석하면, Kang et al.(2017)의 관점과 유사하게 오히려 불확실성을 높이는 것이 경영자가 과신하는 경우 위험추구를 통해 기업가치에 긍정적이라고 해석될 수 있다. 다만 본 연구에서는 보다 장기간 연구 자료를 활용하고 있으며‘경제정책 불확실 완화’의 유의한 조절효과가 일부 모형에서만 제한적으로 확인되어, 전체 분석결과를 Kang et al.(2017)의 관점과 다르게 보수적으로 해석했다.

19) 강건성 검증의 모든 결과는 자료 요청의 경우 제공하겠다. 
Effects of Managerial Overconfidence on the Relationship between Corporate Risk-Taking and Firm Value

잘 대변하지 못하거나, 투자기회나 성장성을 동시에 포착하는 변수로 사용되기도 한다는 점을 보완하기 위해 종종 활용된다. 분석결과 기업가치 및 조절효과 대부분의 분석결과가 종전 Tobin's $\mathrm{Q}$ 를 사용한 경우와 대동소이했다.

〈표 9〉 위험추구-기업가치 관계에서 경영자 과신의 영향에 대한 조절 기제 경영자 과신 여부 $(O C 1, O C 2, O C 3)$ 가 위험추구와 기업가치의 관계에 미치는 효과에 있어 조절 변수 $(O D$, $S D, C D, E D, L D, A D)$ 의 효과를 검증한 결과이다. 각각의 조절 변수는 사외이사 초과 선임 기업 더미 $(O D)$, 이사회 점수 상위 기업 더미 $(S D)$, 재벌집단 소속 기업 여부 $(C D)$, 경제정책 불확실 하위 년도 더미 $(E D)$, 시장 경쟁 강도 하위 산업 더미 $(L D)$, 경영진의 평균 나이 상위 더미 $(A D)$ 이다. 종속변수는 $\mathrm{t}+1$ 년도의 $Q$ 이며, 주 설명변수로는 이하 t년도 연구개발투자비율 $(R N D)$, 주식수익률 변동성 $(R E T V O L)$, 경영자 과신 기업 더미 $(O C 1, O C 2, O C 3)$ 이다. 기업특성변수는 <표 8>과 동일하다. 괄호안의 값은 강건한 표준 오차(robust standard error)를 의미하며 *, *****는 각각 $10 \%, 5 \%$, 그리고 $1 \%$ 유의수준에서 유의적임을 나타낸다.

Panel A: 사외이사 초과 선임 $(O D)$ 의 조절효과

\begin{tabular}{|c|c|c|c|c|c|c|}
\hline & \multicolumn{6}{|c|}{ Tobin's $Q_{t+1}$} \\
\hline & (1) & (2) & (3) & (4) & (5) & (6) \\
\hline 상수항 & $\begin{array}{l}1.474^{* * *} \\
(0.120)\end{array}$ & $\begin{array}{l}1.470^{* * *} \\
(0.120)\end{array}$ & $\begin{array}{l}1.470^{* * * *} \\
(0.120)\end{array}$ & $\begin{array}{l}1^{1.317^{* * *}} \\
(0.121)\end{array}$ & $\begin{array}{l}1.323^{* * *} \\
(0.121)\end{array}$ & $\begin{array}{l}1.322^{* * * *} \\
(0.121)\end{array}$ \\
\hline$R N D_{t} \times O C 1_{t}$ & $\begin{array}{l}-1.398 \\
(0.879)\end{array}$ & & & & & \\
\hline$R N D_{t} \times O C 1_{t} \times O D_{t}$ & $\begin{array}{l}-1.862 \\
(2.142)\end{array}$ & & & & & \\
\hline$R N D_{t} \times O C 2_{t}$ & & $\begin{array}{l}-1.634^{* *} \\
(0.761)\end{array}$ & & & & \\
\hline$R N D_{t} \times O C 2_{t} \times O D_{t}$ & & $\begin{array}{r}0.440 \\
(2.052)\end{array}$ & & & & \\
\hline$R N D_{t} \times O C 3_{t}$ & & & $\begin{array}{l}-2.772^{* * *} \\
(0.957)\end{array}$ & & & \\
\hline$R N D_{t} \times O C 3_{t} \times O D_{t}$ & & & $\begin{array}{l}-1.276 \\
(3.618)\end{array}$ & & & \\
\hline$R E T V O L_{t} \times O C 1_{t}$ & & & & $\begin{array}{l}-4.588^{* * *} \\
(1.676)\end{array}$ & & \\
\hline$R E T V O L_{t} \times O C 1_{t} \times O D_{t}$ & & & & $\begin{array}{l}-2.754 \\
(5.921)\end{array}$ & & \\
\hline$R E T V O L_{t} \times O C 2_{t}$ & & & & & $\begin{array}{l}-2.878^{* *} \\
(1.412)\end{array}$ & \\
\hline$R E T V O L_{t} \times O C 2_{t} \times O D_{t}$ & & & & & $\begin{array}{r}0.069 \\
(6.987)\end{array}$ & \\
\hline$R E T V O L_{t} \times O C 3_{t}$ & & & & & & $\begin{array}{l}-5.512^{*} \\
(3.161)\end{array}$ \\
\hline$R E T V O L_{t} \times O C 3_{t} \times O D_{t}$ & & & & & & $\begin{array}{l}-2.288 \\
(6.681)\end{array}$ \\
\hline$O C 1_{t} \times O D_{t}$ & $\begin{array}{r}0.020 \\
(0.058)\end{array}$ & & & $\begin{array}{r}0.057 \\
(0.158)\end{array}$ & & \\
\hline
\end{tabular}


한국증권학회지 제48권 5호 (2019)

〈표 9〉 위험추구-기업가치 관계에서 경영자 과신의 영향에 대한 조절 기제(계속)

\begin{tabular}{|c|c|c|c|c|c|c|}
\hline & \multicolumn{6}{|c|}{ Tobin's $Q_{t+1}$} \\
\hline & (1) & (2) & (3) & (4) & (5) & (6) \\
\hline $\mathrm{OCl}_{t}$ & $\begin{array}{r}0.037 \\
(0.024)\end{array}$ & & & $\begin{array}{c}0.157^{* * *} \\
(0.054)\end{array}$ & & \\
\hline$O C 2_{t} \times O D_{t}$ & & $\begin{array}{r}0.052 \\
(0.061)\end{array}$ & & & $\begin{array}{r}0.057 \\
(0.182)\end{array}$ & \\
\hline$O C 2_{t}$ & & $\begin{array}{r}0.017 \\
(0.018)\end{array}$ & & & $\begin{array}{c}0.081^{*} \\
(0.044)\end{array}$ & \\
\hline$O C 3_{t} \times O D_{t}$ & & & $\begin{array}{r}0.076 \\
(0.093)\end{array}$ & & & $\begin{array}{r}0.105 \\
(0.193)\end{array}$ \\
\hline$O C 3_{t}$ & & & $\begin{array}{r}0.061 \\
(0.037)\end{array}$ & & & $\begin{array}{c}0.173^{*} \\
(0.100)\end{array}$ \\
\hline$R N D_{t} \times O D_{t}$ & $\begin{array}{c}2.007^{* *} \\
(0.982)\end{array}$ & $\begin{array}{c}1.611^{*} \\
(0.975)\end{array}$ & $\begin{array}{c}1.725^{*} \\
(0.929)\end{array}$ & & & \\
\hline$R N D_{t}$ & $\begin{array}{c}1.461^{* * * *} \\
(0.358)\end{array}$ & $\begin{array}{c}1.473^{* * *} \\
(0.360)\end{array}$ & $\begin{array}{c}1.490^{* * *} \\
(0.352)\end{array}$ & & & \\
\hline$R E T V O L_{t} \times O D_{t}$ & & & & $\begin{array}{l}-1.220 \\
(1.754)\end{array}$ & $\begin{array}{l}-1.364 \\
(1.737)\end{array}$ & $\begin{array}{l}-1.242 \\
(1.722)\end{array}$ \\
\hline$R E T V O L_{t}$ & & & & $\begin{array}{c}2.576^{* * *} \\
(0.638)\end{array}$ & $\begin{array}{c}2.423^{* * * *} \\
(0.633)\end{array}$ & $\begin{array}{c}2.382^{* * * *} \\
(0.615)\end{array}$ \\
\hline$O D_{t}$ & $\begin{array}{l}-0.026 \\
(0.017)\end{array}$ & $\begin{array}{l}-0.027 \\
(0.017)\end{array}$ & $\begin{array}{l}-0.026 \\
(0.016)\end{array}$ & $\begin{array}{r}0.041 \\
(0.049)\end{array}$ & $\begin{array}{r}0.039 \\
(0.048)\end{array}$ & $\begin{array}{r}0.038 \\
(0.048)\end{array}$ \\
\hline $\operatorname{SIZE}_{t}$ & $\begin{array}{l}-0.018^{* * *} \\
(0.004)\end{array}$ & $\begin{array}{l}-0.018^{* * *} \\
(0.004)\end{array}$ & $\begin{array}{l}-0.018^{* * *} \\
(0.004)\end{array}$ & $\begin{array}{l}-0.015^{* * *} \\
(0.004)\end{array}$ & $\begin{array}{l}-0.014^{* * *} \\
(0.004)\end{array}$ & $\begin{array}{l}-0.014^{* * *} \\
(0.004)\end{array}$ \\
\hline $\mathrm{PROFIT}_{t}$ & $\begin{array}{r}0.084 \\
(0.130)\end{array}$ & $\begin{array}{r}0.093 \\
(0.131)\end{array}$ & $\begin{array}{r}0.089 \\
(0.130)\end{array}$ & $\begin{array}{r}0.163 \\
(0.131)\end{array}$ & $\begin{array}{r}0.169 \\
(0.131)\end{array}$ & $\begin{array}{r}0.160 \\
(0.130)\end{array}$ \\
\hline$L E V_{t}$ & $\begin{array}{l}-0.009 \\
(0.033)\end{array}$ & $\begin{array}{l}-0.006 \\
(0.033)\end{array}$ & $\begin{array}{l}-0.006 \\
(0.032)\end{array}$ & $\begin{array}{l}-0.035 \\
(0.034)\end{array}$ & $\begin{array}{l}-0.030 \\
(0.034)\end{array}$ & $\begin{array}{r}-0.030 \\
(0.034)\end{array}$ \\
\hline$F A G E_{t}$ & $\begin{array}{l}-0.036^{* * *} \\
(0.008)\end{array}$ & $\begin{array}{l}-0.035^{* * *} \\
(0.008)\end{array}$ & $\begin{array}{l}-0.036^{* * *} \\
(0.008)\end{array}$ & $\begin{array}{l}-0.038^{* * *} \\
(0.008)\end{array}$ & $\begin{array}{l}-0.038^{* * *} \\
(0.008)\end{array}$ & $\begin{array}{l}-0.038^{* * *} \\
(0.008)\end{array}$ \\
\hline$S G_{t}$ & $\begin{array}{r}0.012 \\
(0.020)\end{array}$ & $\begin{array}{r}0.014 \\
(0.020)\end{array}$ & $\begin{array}{r}0.013 \\
(0.020)\end{array}$ & $\begin{array}{r}0.014 \\
(0.021)\end{array}$ & $\begin{array}{r}0.015 \\
(0.021)\end{array}$ & $\begin{array}{r}0.015 \\
(0.021)\end{array}$ \\
\hline$F O R_{t}$ & $\begin{array}{c}0.306^{* * *} \\
(0.046)\end{array}$ & $\begin{array}{c}0.305^{* * *} \\
(0.046)\end{array}$ & $\begin{array}{c}0.303^{* * *} \\
(0.045)\end{array}$ & $\begin{array}{c}0.335^{* * *} \\
(0.045)\end{array}$ & $\begin{array}{c}0.336^{* * *} \\
(0.045)\end{array}$ & $\begin{array}{c}0.333^{* * *} \\
(0.045)\end{array}$ \\
\hline$O W N_{t}$ & $\begin{array}{l}-0.126^{* * *} \\
(0.036)\end{array}$ & $\begin{array}{l}-0.1266^{* * *} \\
(0.036)\end{array}$ & $\begin{array}{l}-0.125^{* * *} \\
(0.036)\end{array}$ & $\begin{array}{l}-0.113^{* * *} \\
(0.036)\end{array}$ & $\begin{array}{l}-0.112^{* * * *} \\
(0.036)\end{array}$ & $\begin{array}{l}-0.112^{* * *} \\
(0.036)\end{array}$ \\
\hline$C F_{t}$ & $\begin{array}{c}0.204^{* *} \\
(0.083)\end{array}$ & $\begin{array}{c}0.200^{* * *} \\
(0.084)\end{array}$ & $\begin{array}{c}0.202^{* *} \\
(0.083)\end{array}$ & $\begin{array}{c}0.234^{* * *} \\
(0.083)\end{array}$ & $\begin{array}{c}0.227^{* * * *} \\
(0.083)\end{array}$ & $\begin{array}{c}0.232^{* * *} \\
(0.083)\end{array}$ \\
\hline $\begin{array}{l}Q_{t} \\
\text { 연도, 산업 더미 }\end{array}$ & $\begin{array}{l}0.329^{* * *} \\
(0.012) \\
\text { 포함 }\end{array}$ & $\begin{array}{c}0.329^{* * * *} \\
(0.012) \\
\text { 포함 }\end{array}$ & $\begin{array}{c}0.329^{* * *} \\
(0.012) \\
\text { 포함 }\end{array}$ & $\begin{array}{c}0.329^{* * *} \\
(0.012) \\
\text { 포함 }\end{array}$ & $\begin{array}{c}0.329^{* * *} \\
(0.012) \\
\text { 포함 }\end{array}$ & $\begin{array}{c}0.329^{* * *} \\
(0.012) \\
\text { 포함 }\end{array}$ \\
\hline $\begin{array}{l}\text { No. of Obs. } \\
\text { F-Value } \\
\text { Adj. } R^{2}\end{array}$ & \begin{tabular}{l}
\multicolumn{1}{c}{8,013} \\
$80.184^{* * *}$ \\
0.5403
\end{tabular} & $\begin{array}{l}8,013 \\
81.483^{* * *} \\
0.5401\end{array}$ & $\begin{array}{l}\text { 8,013 } \\
81.169^{* * *} \\
0.5404\end{array}$ & \begin{tabular}{l}
\multicolumn{1}{c}{8,013} \\
$83.333^{* * *}$ \\
0.5383
\end{tabular} & \begin{tabular}{l}
\multicolumn{1}{c}{8,013} \\
$83.381^{* * *}$ \\
0.5383
\end{tabular} & $\begin{array}{l}8,013 \\
83.183^{* * *} \\
0.5381\end{array}$ \\
\hline
\end{tabular}


Effects of Managerial Overconfidence on the Relationship between Corporate Risk-Taking and Firm Value

〈표 9〉 위험추구-기업가치 관계에서 경영자 과신의 영향에 대한 조절 기제(계속) Panel B: 이사회 점수 상위 기업 더미 $(S D)$ 의 조절효과

\begin{tabular}{|c|c|c|c|c|c|c|}
\hline & \multicolumn{6}{|c|}{ Tobin's $Q_{t+1}$} \\
\hline & (1) & (2) & (3) & (4) & (5) & (6) \\
\hline 상수항 & $\begin{array}{l}1.475^{\text {*** }} \\
(0.131)\end{array}$ & $\begin{array}{l}1.471^{\text {*** }} \\
(0.131)\end{array}$ & $\begin{array}{l}1.471^{\text {*** }} \\
(0.131)\end{array}$ & $\begin{array}{l}1.296^{* * *} \\
(0.131)\end{array}$ & $\begin{array}{l}1.306^{* * *} \\
(0.131)\end{array}$ & $\begin{array}{l}1.302^{* * *} \\
(0.131)\end{array}$ \\
\hline$R N D_{t} \times O C 1_{t}$ & $\begin{array}{l}-1.757 \\
(1.073)\end{array}$ & & & & & \\
\hline$R N D_{t} \times O C 1_{t} \times S D_{t}$ & $\begin{array}{l}-1.045 \\
(1.500)\end{array}$ & & & & & \\
\hline$R N D_{t} \times O C 2_{t}$ & & $\begin{array}{l}-1.477 \\
(0.952)\end{array}$ & & & & \\
\hline$R N D_{t} \times O C 2_{t} \times S D_{t}$ & & $\begin{array}{l}-0.550 \\
(1.335)\end{array}$ & & & & \\
\hline$R N D_{t} \times O C 3_{t}$ & & & $\begin{array}{l}-1.358 \\
(1.567)\end{array}$ & & & \\
\hline$R N D_{t} \times O C 3_{t} \times S D_{t}$ & & & $\begin{array}{l}-2.694 \\
(2.014)\end{array}$ & & & \\
\hline$R E T V O L_{t} \times O C 1_{t}$ & & & & $\begin{array}{l}-5.117^{* *} \\
(2.558)\end{array}$ & & \\
\hline$R E T V O L_{t} \times O C 1_{t} \times S D_{t}$ & & & & $\begin{array}{l}-0.129 \\
(3.522)\end{array}$ & & \\
\hline$R E T V O L_{t} \times O C 2_{t}$ & & & & & $\begin{array}{l}-2.465 \\
(1.621)\end{array}$ & \\
\hline$R E T V O L_{t} \times O C 2_{t} \times S D_{t}$ & & & & & $\begin{array}{l}-1.335 \\
(3.047)\end{array}$ & \\
\hline$R E T V O L_{t} \times O C 3_{t}$ & & & & & & $\begin{array}{l}-6.106^{*} \\
(3.639)\end{array}$ \\
\hline$R E T V O L_{t} \times O C 3_{t} \times S D_{t}$ & & & & & & $\begin{array}{l}-0.170 \\
(5.493)\end{array}$ \\
\hline $\begin{array}{l}\text { 기타 통제 변수, } \\
\text { 연도, 산업 더미 }\end{array}$ & 포함 & 포함 & 포함 & 포함 & 포함 & 포함 \\
\hline No. of Obs. & 7,260 & 7,260 & 7,260 & 7,260 & 7,260 & 7,260 \\
\hline F-Value & $77.907^{* * *}$ & $78.249^{* * *}$ & $78.930^{* * *}$ & $78.571^{\text {*** }}$ & $78.301^{\text {*** }}$ & $78.334^{* * *}$ \\
\hline Adj. $R^{2}$ & 0.5329 & 0.5324 & 0.5330 & 0.5318 & 0.5313 & 0.5315 \\
\hline
\end{tabular}

Panel C: 재벌 소속 기업 더미 $(C D)$ 의 조절효과

\begin{tabular}{lcccccc}
\hline & \multicolumn{7}{c}{ Tobin's } & $Q_{t+1}$ \\
\cline { 2 - 6 } & $(1)$ & $(2)$ & $(3)$ & $(4)$ & $(5)$ & $(6)$ \\
\hline 상수항 & $1.637^{* * *}$ & $1.630^{* * *}$ & $1.634^{* * *}$ & $1.488^{* * *}$ & $1.491^{* * *}$ & $1.485^{* * *}$ \\
& $(0.139)$ & $(0.139)$ & $(0.139)$ & $(0.137)$ & $(0.137)$ & $(0.137)$ \\
$R N D_{t} \times O C 1_{t}$ & $-1.655^{*}$ & & & & & \\
& $(0.983)$ & & & & \\
\hline
\end{tabular}


한국증권학회지 제48권 5호 (2019)

〈표 9〉 위험추구-기업가치 관계에서 경영자 과신의 영향에 대한 조절 기제(계속)

\begin{tabular}{|c|c|c|c|c|c|c|}
\hline & \multicolumn{6}{|c|}{ Tobin's $Q_{t+1}$} \\
\hline & (1) & (2) & (3) & (4) & (5) & (6) \\
\hline$R N D_{t} \times O C 1_{t} \times C D_{t}$ & $\begin{array}{l}-0.933 \\
(1.789)\end{array}$ & & & & & \\
\hline$R N D_{t} \times O C 2_{t}$ & & $\begin{array}{l}-1.543^{*} \\
(0.832)\end{array}$ & & & & \\
\hline$R N D_{t} \times O C 2_{t} \times C D_{t}$ & & $\begin{array}{l}-0.568 \\
(1.464)\end{array}$ & & & & \\
\hline$R N D_{t} \times O C 3_{t}$ & & & $\begin{array}{l}-2.746^{* * *} \\
(1.129)\end{array}$ & & & \\
\hline$R N D_{t} \times O C 3_{t} \times C D_{t}$ & & & $\begin{array}{l}-1.164 \\
(2.120)\end{array}$ & & & \\
\hline$R E T V O L_{t} \times O C 1_{t}$ & & & & $\begin{array}{l}-4.775^{* *} \\
(1.982)\end{array}$ & & \\
\hline$R E T V O L_{t} \times O C 1_{t} \times C D_{t}$ & & & & $\begin{array}{l}-1.848 \\
(3.555)\end{array}$ & & \\
\hline$R E T V O L_{t} \times O C 2_{t}$ & & & & & $\begin{array}{l}-2.020 \\
(1.443)\end{array}$ & \\
\hline$R E T V O L_{t} \times O C 2_{t} \times C D_{t}$ & & & & & $\begin{array}{l}-3.121 \\
(4.198)\end{array}$ & \\
\hline$R E T V O L_{t} \times O C 3_{t}$ & & & & & & $\begin{array}{l}-6.151^{* *} \\
(3.111)\end{array}$ \\
\hline$R E T V O L_{t} \times O C 3_{t} \times C D_{t}$ & & & & & & $\begin{array}{r}0.113 \\
(6.403)\end{array}$ \\
\hline $\begin{array}{l}\text { 기타 통제 변수, } \\
\text { 연도, 산업 더미 }\end{array}$ & 포함 & 포함 & 포함 & 포함 & 포함 & 포함 \\
\hline No. of Obs. & 8,086 & 8,086 & 8,086 & 8,086 & 8,086 & 8,086 \\
\hline $\mathrm{F}$-Value & $82.998^{* * *}$ & $81.196^{* * *}$ & $82.219^{* * *}$ & $84.558^{* * *}$ & $84.441^{* * *}$ & $84.332^{* * *}$ \\
\hline Adj. $R^{2}$ & 0.5396 & 0.5394 & 0.5398 & 0.5377 & 0.5372 & 0.5373 \\
\hline \multicolumn{7}{|c|}{ Panel D: 경제정책 불확실 하위 년도 더미 $(E D)$ 의 조절효과 } \\
\hline & \multicolumn{6}{|c|}{ Tobin's $Q_{t+1}$} \\
\hline & (1) & $(2)$ & (3) & (4) & (5) & (6) \\
\hline 상수항 & $\begin{array}{l}1.258^{* * *} \\
(0.114)\end{array}$ & $\begin{array}{l}1.249^{* * *} \\
(0.114)\end{array}$ & $\begin{array}{l}1.251^{* * *} \\
(0.115)\end{array}$ & $\begin{array}{l}1.090^{* * *} \\
(0.118)\end{array}$ & $\begin{array}{l}1.085^{* * *} \\
(0.118)\end{array}$ & $\begin{array}{l}1.084^{* * * *} \\
(0.118)\end{array}$ \\
\hline$R N D_{t} \times O C 1_{t}$ & $\begin{array}{l}-1.037 \\
(0.911)\end{array}$ & & & & & \\
\hline$R N D_{t} \times O C 1_{t} \times E D_{t}$ & $\begin{array}{l}-1.736 \\
(1.660)\end{array}$ & & & & & \\
\hline$R N D_{t} \times O C 2_{t}$ & & $\begin{array}{l}-1.970^{* *} \\
(0.947)\end{array}$ & & & & \\
\hline$R N D_{t} \times O C 2_{t} \times E D_{t}$ & & $\begin{array}{r}0.452 \\
(1.398) \\
\end{array}$ & & & & \\
\hline
\end{tabular}


Effects of Managerial Overconfidence on the Relationship between Corporate Risk-Taking and Firm Value

〈표 9〉 위험추구-기업가치 관계에서 경영자 과신의 영향에 대한 조절 기제(계속)

\begin{tabular}{|c|c|c|c|c|c|c|}
\hline & \multicolumn{6}{|c|}{ Tobin's $Q_{t+1}$} \\
\hline & (1) & (2) & (3) & (4) & (5) & (6) \\
\hline$R N D_{t} \times O C 3_{t}$ & & & $\begin{array}{l}-2.607^{* * *} \\
(0.981)\end{array}$ & & & \\
\hline$R N D_{t} \times O C 3_{t} \times E D_{t}$ & & & $\begin{array}{l}-1.078 \\
(1.965)\end{array}$ & & & \\
\hline$R E T V O L_{t} \times O C 1_{t}$ & & & & $\begin{array}{l}-1.711 \\
(1.518)\end{array}$ & & \\
\hline$R E T V O L_{t} \times O C 1_{t} \times E D_{t}$ & & & & $\begin{array}{l}-7.642^{* *} \\
(3.475)\end{array}$ & & \\
\hline$R E T V O L_{t} \times O C 2_{t}$ & & & & & $\begin{array}{l}-2.476 \\
(1.860)\end{array}$ & \\
\hline$R E T V O L_{t} \times O C 2_{t} \times E D_{t}$ & & & & & $\begin{array}{l}-1.277 \\
(3.022)\end{array}$ & \\
\hline$R E T V O L_{t} \times O C 3_{t}$ & & & & & & $\begin{array}{l}-2.527 \\
(3.194)\end{array}$ \\
\hline$R E T V O L_{t} \times O C 3_{t} \times E D_{t}$ & & & & & & $\begin{array}{r}-8.111 \\
(5.710)\end{array}$ \\
\hline $\begin{array}{l}\text { 기타 통제 변수, } \\
\text { 연도, 산업 더미 }\end{array}$ & 포함 & 포함 & 포함 & 포함 & 포함 & 포함 \\
\hline No. of Obs. & 8,086 & 8,086 & 8,086 & 8,086 & 8,086 & 8,086 \\
\hline $\mathrm{F}$-Value & $85.032^{* * *}$ & $86.242^{* * *}$ & $86.029^{* * *}$ & $86.007^{* * *}$ & $85.411^{* * *}$ & $85.805^{* * *}$ \\
\hline Adj. $R^{2}$ & 0.5395 & 0.5392 & 0.5397 & 0.5385 & 0.5377 & 0.5381 \\
\hline \multicolumn{7}{|c|}{ Panel E: 시장 경쟁 강도 하위 산업 더미 $(E D)$ 의 조절효과 } \\
\hline & \multicolumn{6}{|c|}{ Tobin's $Q_{t+1}$} \\
\hline & (1) & (2) & (3) & (4) & (5) & (6) \\
\hline 상수항 & $\begin{array}{l}1.460^{* * *} \\
(0.121)\end{array}$ & $\begin{array}{l}1.459^{* * *} \\
(0.121)\end{array}$ & $\begin{array}{l}1.465^{* * *} \\
(0.121)\end{array}$ & $\begin{array}{l}1.303^{* * *} \\
(0.122)\end{array}$ & $\begin{array}{l}1.309^{* * *} \\
(0.122)\end{array}$ & $\begin{array}{l}1.315^{* * *} \\
(0.122)\end{array}$ \\
\hline$R N D_{t} \times O C 1_{t}$ & $\begin{array}{l}-2.535^{* *} \\
(1.029)\end{array}$ & & & & & \\
\hline$R N D_{t} \times O C 1_{t} \times L D_{t}$ & $\begin{array}{r}1.381 \\
(1.681)\end{array}$ & & & & & \\
\hline$R N D_{t} \times O C 2_{t}$ & & $\begin{array}{l}-1.990^{* *} \\
(0.858)\end{array}$ & & & & \\
\hline$R N D_{t} \times O C 2_{t} \times L D_{t}$ & & $\begin{array}{r}0.680 \\
(1.435)\end{array}$ & & & & \\
\hline$R N D_{t} \times O C 3_{t}$ & & & $\begin{array}{l}-1.622 \\
(1.231)\end{array}$ & & & \\
\hline$R N D_{t} \times O C 3_{t} \times L D_{t}$ & & & $\begin{array}{l}-2.977 \\
(1.950)\end{array}$ & & & \\
\hline$R E T V O L_{t} \times O C 1_{t}$ & & & & $\begin{array}{l}-7.581^{* * *} \\
(2.591)\end{array}$ & & \\
\hline
\end{tabular}


한국증권학회지 제48권 5호 (2019)

〈표 9〉 위험추구-기업가치 관계에서 경영자 과신의 영향에 대한 조절 기제(계속)

\begin{tabular}{|c|c|c|c|c|c|c|}
\hline & \multicolumn{6}{|c|}{ Tobin's $Q_{t+1}$} \\
\hline & (1) & $(2)$ & (3) & (4) & (5) & (6) \\
\hline$R E T V O L_{t} \times O C 1_{t} \times L D_{t}$ & & & & $\begin{array}{r}4.945 \\
(3.332)\end{array}$ & & \\
\hline$R E T V O L_{t} \times O C 2_{t}$ & & & & & $\begin{array}{l}-5.980^{* * *} \\
(2.059)\end{array}$ & \\
\hline$R E T V O L_{t} \times O C 2_{t} \times L D_{t}$ & & & & & $\begin{array}{r}5.328 \\
(2.978)\end{array}$ & \\
\hline$R E T V O L_{t} \times O C 3_{t}$ & & & & & & $\begin{array}{c}-10.419^{* *} \\
(4.314)\end{array}$ \\
\hline$R E T V O L_{t} \times O C 3_{t} \times L D_{t}$ & & & & & & $\begin{array}{r}7.656 \\
(5.504)\end{array}$ \\
\hline $\begin{array}{l}\text { 기타 통제 변수, } \\
\text { 연도, 산업 더미 }\end{array}$ & 포함 & 포함 & 포함 & 포함 & 포함 & 포함 \\
\hline No. of Obs. & 8,086 & 8,086 & 8,086 & 8,086 & 8,086 & 8,086 \\
\hline F-Value & $82.729^{* * *}$ & $82.703^{* * *}$ & $82.999^{* * * *}$ & $83.576^{* * *}$ & $83.181^{* * *}$ & $82.749^{* * *}$ \\
\hline Adj. $R^{2}$ & 0.5393 & 0.5392 & 0.5398 & 0.5377 & 0.5373 & 0.5375 \\
\hline \multicolumn{7}{|c|}{ Panel F: 경영진 평균 나이 상위 더미 $(A D)$ 의 조절효과 } \\
\hline & \multicolumn{6}{|c|}{ Tobin's $Q_{t+1}$} \\
\hline & (1) & (2) & (3) & (4) & (5) & (6) \\
\hline 상수항 & $\begin{array}{l}1.338^{* * *} \\
(0.123)\end{array}$ & $\begin{array}{l}1.332^{* * *} \\
(0.122)\end{array}$ & $\begin{array}{l}1.339^{* * *} \\
(0.123)\end{array}$ & $\begin{array}{l}1.258^{* * *} \\
(0.123)\end{array}$ & $\begin{array}{l}1.265^{* * *} \\
(0.123)\end{array}$ & $\begin{array}{l}1.262^{* * *} \\
(0.123)\end{array}$ \\
\hline$R N D_{t} \times O C 1_{t}$ & $\begin{array}{l}-3.345^{* * *} \\
(1.341)\end{array}$ & & & & & \\
\hline$R N D_{t} \times O C 1_{t} \times A D_{t}$ & $\begin{array}{r}3.195^{*} \\
(1.649)\end{array}$ & & & & & \\
\hline$R N D_{t} \times O C 2_{t}$ & & $\begin{array}{l}-3.169^{* * *} \\
(1.068)\end{array}$ & & & & \\
\hline$R N D_{t} \times O C 2_{t} \times A D_{t}$ & & $\begin{array}{c}3.152^{* *} \\
(1.381)\end{array}$ & & & & \\
\hline$R N D_{t} \times O C 3_{t}$ & & & $\begin{array}{l}-5.160^{* * *} \\
(1.738)\end{array}$ & & & \\
\hline$R N D_{t} \times O C 3_{t} \times A D_{t}$ & & & $\begin{array}{c}4.318^{* *} \\
(2.036)\end{array}$ & & & \\
\hline$R E T V O L_{t} \times O C 1_{t}$ & & & & $\begin{array}{l}-4.482^{*} \\
(2.508)\end{array}$ & & \\
\hline$R E T V O L_{t} \times O C 1_{t} \times A D_{t}$ & & & & $\begin{array}{r}0.249 \\
(3.075)\end{array}$ & & \\
\hline$R E T V O L_{t} \times O C 2_{t}$ & & & & & $\begin{array}{l}-2.278 \\
(2.274)\end{array}$ & \\
\hline$R E T V O L_{t} \times O C 2_{t} \times A D_{t}$ & & & & & $\begin{array}{r}1.087 \\
(2.957)\end{array}$ & \\
\hline
\end{tabular}


Effects of Managerial Overconfidence on the Relationship between Corporate Risk-Taking and Firm Value

〈표 9〉 위험추구-기업가치 관계에서 경영자 과신의 영향에 대한 조절 기제(계속)

\begin{tabular}{|c|c|c|c|c|c|c|}
\hline & \multicolumn{6}{|c|}{ Tobin's $Q_{t+1}$} \\
\hline & (1) & (2) & (3) & (4) & (5) & (6) \\
\hline$R E T V O L_{t} \times O C 3_{t}$ & & & & & & $\begin{array}{l}-8.591^{* *} \\
(3.888)\end{array}$ \\
\hline$R E T V O L_{t} \times O C 3_{t} \times A D_{t}$ & & & & & & $\begin{array}{r}6.617^{*} \\
(5.589)\end{array}$ \\
\hline $\begin{array}{l}\text { 기타 통제 변수, } \\
\text { 연도, 산업 더미 }\end{array}$ & 포함 & 포함 & 포함 & 포함 & 포함 & 포함 \\
\hline No. of Obs. & 8,013 & 8,013 & 8,013 & 8,013 & 8,013 & 8,013 \\
\hline F-Value & $81.941^{* * * *}$ & $82.911^{* * *}$ & $82.335^{* * *}$ & $84.130^{* * * *}$ & $84.207^{* * *}$ & $83.772^{* * *}$ \\
\hline Adj. $R^{2}$ & 0.5421 & 0.5419 & 0.5423 & 0.5403 & 0.5400 & 0.5401 \\
\hline
\end{tabular}

두 번째로, 본 연구에서 추론된 과신 기업은 과거 수익률이 상대적으로 우수한 기업을 전제로 한다. 따라서 과신 기업의 미래 기업가치의 하락은 좋은 실적에 대한 주가 과잉반응(overreaction)의 반전현상으로 생각해볼 수도 있다. 따라서 주가 반전으로 인한 기업가치 하락을 어느 정도 벗어날 수 있는 기간으로 기존 종속변수의 시차를 설명변수의 시차(t년)에 2 년 $(\mathrm{t}+2$ 년 $)$ 선행하도록 모형을 수정하고 추가 분석을 실시했다. 실증분석결과로부터 기업가치 및 조절효과 대부분의 설명이 종전의 차년(t+1년) Tobin's $\mathrm{Q}$ 를 사용한 경우와 유사함을 확인하였다. ${ }^{20)}$

세 번째로, 기존 더미 형태의 과신 변수를 활용하는 대신'과신 수준'정도를 측정하고 활용해 기존 결과를 재검토하였다. 과신 수준 변수는 경영자 과신 기업을 식별할 때 사용된 4 가지 측정변수인 과거 성과, 투자, 부채, 낙관적인 경영자의 이익전망 자료를 조합해 추정하되, 각 측정 변수가 과신에 해당하는 경우 1점씩 부여한 뒤 이를 모두 합산하여 구성하였다. 이러한 과신 점수 변수는 과신 가능성이 가장 낮은 0점부터 가장 높은 4점으로 측정되어 있어, 과신 수준에 따른 검증을 일부 고려하게 해 준다.21) 과신 점수를 활용해 가설 1 을 분석한 결과, 경영자의 과신 수준이 증가할수록 위험 추구로 인한 기업가치의 관계가 부정적이었다. 과신 점수를 활용해 조절 요인의 유효성을 확인한 분석결과 역시 기존의 결과와 대부분 유사했는데, 일부 차별적인 것은 가설 2 와 관련해 사외이사를 초과 선임하는 경우 기존 경영자 과신의 비 유의적이었던 영향이 유의적인 음(-)의 역할로 확인되었다. 이는 경영자의 과신 수준이 높은 기업에서는 기업의 자발적인 사외이사 초과 선임 함에도 불구하고, 이사회의 실질적인 독립성이 확보되지 못해 과신 경영자의 의사결정이 통제되기 어렵다는 것을 보여주는 결과로 판단된다.

네 번째 강건성 분석으로, 본 연구는 경영자 과신 여부를 기준으로 더미 변수 대신 표본을 분리하여 검증하였다. 이러한 분석은 각 하위 표본을 통해 기존의 결과가 유사하게 설명되는지를

20) 이 부분을 검토할 수 있도록 의견주신 2018년 재무 통합학술대회 토론자 분께 감사드린다.

21) 과신 수준을 비율척도(ratio scale)로 구성하지 않고, 순위 점수와 같은 서열척도(ordinal scale)로 측정한 이유는 본 연구의 과신 측정변수 중 '낙관적인 경영자의 이익전망'의 경우 기업이 각기 다른 이익(예로 영업이익, 순이익 등)을 선택적으로 보고하고 있어 표준화하더라도 그 정도를 상호 비교하기 어렵다는 측면 때문이었다. 
한국증권학회지 제48권 5호 (2019)

확인하는 목적을 갖는다. 분석결과 경영자가 과신하지 않는 비 과신 그룹에서는 기업의 위험추구 활동으로부터 기업가치가 제고되고 있었지만, 경영자가 과신하는 그룹에서는 기업의 위험추구 활동이 기업가치를 훼손하거나 가치 증가에 기여하지 못함을 알 수 있었다. 결과적으로 과신 여부에 따른 그룹별 분석 역시 기존 분석결과의 주장과 일관된 설명을 가능케 한다.

마지막으로, 본 연구는 이상에서 살펴본 경영자 과신의 부정적 효과가 모든 기업에서 일반적인 것인지? 특정 산업에서 경영자의 과신이 긍정적으로 작용함에도 불구하고, 나머지 산업 표본 내에 과신의 부정적인 효과가 지배적인 것이어서 그러한 결과가 유도된 것인지?를 추가로 확인하였다. 과신 성향의 경영자는 혁신이 중요한 산업 내에서 성장기회가 있는 기업의 혁신 활동을 증가시키고 그 결과 기업가치를 제고시킬 수 있다(Hirshleifer et al., 2012). 따라서 본 연구의 결과가 일부 혁신이 중요한 산업에서는 경영자 과신의 효과가 긍정적임에도 불구하고, 나머지 기업들의 부정적인 효과가 지배적이어서 초래된 결과일 가능성이 있어 이를 추가로 검증하였다. 이를 위해 연도 내 산업 평균 연구개발투자 비율이 중위수 이상인 산업을 혁신 산업군으로 구분하고 나머지 산업을 비 혁신 산업군으로 구분한 뒤, 각각 두 하위 표본을 대상으로 경영자 과신의 효과를 재검토하였다. 분석결과 Hirshleifer et al.(2012)의 설명과는 달리 국내 기업의 경우 혁신 산업군 내에서 오히려 과신의 부정적인 효과가 보다 뚜렷했다. 따라서 국내 기업의 경우 경영자의 과신은 적어도 혁신 산업이나 비 혁신 산업 모두에서 긍정적으로 작용하기 어렵다는 것을 확인하였다. 역시 표는 생략하였지만 가설 2 가설 6의 조절효과의 경우에도 혁신 및 비혁신 산업에 따라 기존 연구결과와 일관된 설명을 견지했다.

\section{5. 결론 및 시사점}

본 연구는 행태기업재무 분야의 선행연구들을 토대로 국내 기업의 위험추구와 기업가치의 관계에서 경영자 과신의 효과를 실증 검증하고 있다. 이에 더해 본 연구는 내·외부 지배구조 및 개인의 인적 특성을 고려해 과신의 조절 요인을 폭 넓은 관점에서 검토하며 이로부터 시사점을 도출하고 있다.

분석결과 국내 기업의 위험추구는 기업가치를 증가시키지만, 경영자가 과신하는 경우 이러한 위험추구는 기업가치를 하락시키고 있었다. 이를 통해 기존 대리인 문제 이외에도 행태론적 관점에서 경영자의 과신이 기업 현실에 부적절하거나 과도한 위험추구와 관련된 의사결정을 유도해 국내 기업 경영에 부정적일 수 있다는 결론을 얻었다. 동시에 이러한 결과는 국내 기업의 대리인 문제가 해소된다 하더라도 경영자의 과신에 의해 주주 부가 훼손될 여지가 존재한다는 점을 의미한다.

추가로 본 연구는 선행연구를 토대로 지배구조 및 인적 특성 관점에서 과신의 부정적 효과를 조절하는 요인을 종합적으로 검증하였다. 분석결과 기존의 연구 관점과 달리 사외이사 초과 선임, 상대적으로 양호한 이사회 역할, 재벌집단 소속 등 이사회 및 조직 구조상의 내부 지배구조 요인이 과신 경영자를 통제한다는 근거는 찾지 못하였다. 마찬가지로 경제정책 불확실의 완화, 산업 내 경쟁 축소와 같은 거시적 또는 산업 구조적인 외부 지배구조 요인들이 경영자 과신의 
Effects of Managerial Overconfidence on the Relationship between Corporate Risk-Taking and Firm Value

부정적 효과를 완화시킨다는 강건한 결과 역시 얻지 못했다. 오히려 본 연구는 인적 특성 관점에서 경영자의 평균 나이가 많은 경우 경영자 과신에 따른 기업가치 하락이 일부 완화되는 것을 확인하였다. 따라서 과거 국내 기업의 경우 경영자 과신으로 파생되는 위험추구의 결과 즉, 궁극적인 기업가치 하락은 기업 내·외부의 지배구조 요인보다 심리적 편의의 주체인 경영자의 인적 특성에 보다 의존할 수 있음을 확인하였다. 이러한 분석결과는 종속변수, 과신변수, 연구모형을 수정한 경우 및 하위 표본 분석을 실시한 경우에도 일관되게 도출되었다.

이상의 결과로부터 본 연구는 다음과 같은 기업 실무 및 정책적 시사점을 제시한다. 첫째, 경영자 과신의 부정적 효과가 존재하며 이것이 경영자의 인적 특성과 연관되어 있다는 점을 토대로, 경영자 스스로의 과신 가능성을 경계하는 노력이 선행될 필요성을 제시한다. 이를 위해 경영자는 과신의 원인을 근본적으로 이해함으로써, 과신에 이르기 쉬운 상황에 노출되는 경우 이를 자각하고 의사결정에 주의를 기울여야 할 것이다. 선행연구들은 언론매체에 언급되는 경영자의 칭찬이나 상대적으로 높은 보상에 기인한 과도한 자존감, 성공적인 조직성과를 자기 귀인 시키는 성향, 나르시시즘적인 성격, 조직 내 높은 파워 등이 경영자 과신의 일부 원인이 되거나 그 정도를 강화시킬 수 있다고 지적한다(Hayward and Hambrick, 1997; Kroll et al., 2000; Hwang et al., 2018). 부가적으로 본 연구의 관점과 유사하게 경영자의 인구 통계적 요인도 이들의 심리적 특성을 변화시켜 과신 정도에 영향을 미칠 수 있다. 따라서 이러한 과신 원인과 연관된 경영자의 내·외부적 요인의 존재에도 불구하고, 경영자는 자신의 의사결정에 객관성과 합리성을 유지하려는 시각을 잃지 말아야 할 것이다.

둘째, 본 연구는 경영자의 과신을 통제하기 위한 보조 장치로 여러 지배구조 요인 중에서도 이사회의 역할 보완이 필요함을 강조한다. 이는 여타의 지배구조 요인들에 비해 이사회가 경영자의 직무집행을 직접 감독할 뿐만 아니라 포괄적인 기업 의사결정에 참여하는 가장 핵심적인 위치에 있기 때문이다. 더욱이 이사회는 경영자의 보상 수준이나 권한 등에 영향을 미쳐 경영자 과신을 유도할 수 있고(Hwang et al., 2018), 이론적으로 위험추구에 적극적인 과신 성향의 경영자를 선임할 가능성을 높인다는 점(Goel and Thakor, 2008)에서 과신적 경영자와 무관하지 않기 때문이다. 본 연구는 이사회의 내부적인 경영 견제 노력과 함께 이사회의 운영의 실효성을 높이는 제도적 보완이 필요함을 제언한다. 보다 구체적으로, 이사회는 내부 보상체계 및 조직구조 등을 활용해 경영자의 조직 내 권한이 과도하게 집중되지 않도록 함으로써 경영자의 과신 유인을 낮추는 것을 고려해 볼 수 있다. 한편 과신 경영자의 독단적 의사결정을 견제하기 위해, 이사회의 독립성과 책임성을 강화하는 지배구조상의 제도적 보완을 지속하면서 경영자의 비합리적 의사결정에 대해 객관적인 평가가 가능하도록 이사회의 전문성 확보 방안도 추가로 고민해야 할 것이다. 관련해 기업지배구조 공시자료에 사외이사 등의 전문성 항목 포함을 검토하거나, 이사회 역량 구성표 공시 제안 등과 같은 최근 정부와 유관 기관의 관심이 비단 대리인 문제 해소만을 유도하지는 않을 것으로 본다. 향후 이사회의 역할은 지배주주 및 경영자의 대리인 문제를 해소하기 위한 내부 지배구조 요인으로서 존재할 뿐만 아니라, 경영자의 과신이 존재할 경우 이를 통제하는 기능도 겸할 필요가 있을 것이다. 
한국증권학회지 제 48 권 5 호 (2019)

\section{References}

Adam, T. R., C. S. Fernando, and E. Golubeva, 2015, Managerial Overconfidence and Corporate Risk Management, Journal of Banking and Finance, Vol. 60, pp. 195-208.

Bae, K.-H., and C.-W. Lim, 2003, Why Are Stock Returns of Bussiness Groups Positively Skewed? Evidence from Korean Business Groups, The Korean Journal of Finance, Vol. 16 (1), pp. 39-68.

Baker, M., and J. Wurgler, Behavioral Corporate Finance: An Updated Survey, Handbook of the Economics of Finance, 2A: Corporate Finance Ch. 5, 2013.

Baker, S. R., N. Bloom, and S. J. Davis, 2016, Measuring Economic Policy Uncertainty, The Quarterly Journal of Economics, Vol. 131 (4), pp. 1593-1636.

Barker, V. L., and G. C. Mueller, 2002, CEO Characteristics and Firm R\&D Spending, Management Science, Vol. 48 (6), pp. 782-801.

Barros, L. A. B., and A. D. M. Silveira, Overconfidence, Managerial Optimism and the Determinants of Capital Structure, Working Paper, SSRN, 2007.

Ben-David, I., J. R. Graham, and C. R. Harvey, 2013, Managerial Miscalibration, Quarterly Journal of Economics, Vol. 128 (4), pp. 1547-1584.

Bertrand, M., and A. Schoar, 2003, Managing with Style: The effect of Managers on Firm Policies, The Quarterly Journal of Economics, Vol. 118 (4), pp. 116-1208.

Bhagat, S., and B. Black, 1999, The Uncertain Relationship between Board Composition and Firm Performance, The Business Lawyer, Vol. 54 (3), pp. 921-963.

Bhagat, S., and B. Black, 2002, The Non-Correlation between Board Independence and Long-Term Firm Performance, Journal of Corporation Law, Vol. 27 (2), pp. 231-274.

Bharati, R., T. Doellman, and X. Fu, 2016, CEO Confidence and Stock Returns, Journal of Contemporary Accounting and Economics, Vol. 12, pp. 89-110.

Billett, M. T., and Y. Qian, 2008, Are Overconfident CEOs Born or Made? Evidence of Self-Attribution Bias from Frequent Acquirers, Management Science, Vol. 54 (6), pp. 1037-1051.

Campbell, T. C., 2014, CEO Optimism and the Board's Choice of Successor, Journal of Corporate Finance, Vol. 29, pp. 495-510.

Campbell, T. C., M. Gallmeyer, S. A. Johnson, J. Rutherford, and B. W. Stanley, 2011, CEO Optimism and Forced Turnover, Journal of Financial Economics, Vol. 101 (3), pp. 695-712. Cha, M. K., S. S. Kim, and K. J. Hwang, 2016, Financial Crisis and Corporate Governance, Korean Accounting Information Review, Vol. 34 (4), pp. 441-485.

Chang, J. J., and H.-H. Shin, 2006, Governance System Effectiveness Following the Crisis: 
Effects of Managerial Overconfidence on the Relationship between Corporate Risk-Taking and Firm Value

The Case of Korean Business Group Headquarters, Corporate Governance: An International Review, Vol. 14 (2), pp. 85-97.

Chen, S.-S., K.-Y. Ho, and P.-H. Ho, 2014, CEO Overconfidence and Long-Term Performance Following R\&D Increases, Financial Management, Vol. 43 (2), pp. 245-269.

Cho, S.-S., H.-H., Shin, and S. Park, 2016, Financial Crisis and Corporate Governance, The Korean Journal of Financial Management, Vol. 33 (1), pp. 215-252.

Fazzari, S. M., R. G. Hubbard, and B. C. Petersen, 1988, Financing Constraints and Corporate Investment, Brookings Papers on Economic Activity, Vol. 1, pp. 141-206.

Fields, M. A., and P. Y. Keys, 2003, The Emergence of Corporate Governance from Wall St. to Main St: Outside Directors, Board Diversity, Earnings Management, and Managerial Incentives to Bear Risk, The Financial Review, Vol. 38 (1), pp. 1-24.

Galasso, A., and T. S. Simcoe, 2011, CEO Overconfidence and Innovation, Management Science, Vol. 57 (8), pp. 1469-1484.

Gervais, S., J. B. Heaton, and T. Odean, 2011, Overconfidence, Compensation Contracts, and Capital Budgeting, Journal of Finance, Vol. 66 (5), pp. 1735-1777.

Goel, A. M., and A. V. Thakor, 2008, Overconfidence, CEO Selection, and Corporate Governance, Journal of Finance, Vol. 63 (6), pp. 2737-2784.

Griffith, R., Product Market Competition, Efficiency and Agency Costs: An Empirical Analysis, Working Paper, The Institute for Fiscal Studies, 2001.

Hackbarth, D., 2008, Managerial Traits and Capital Structure Decisions, Journal of Financial and Quantitative Analysis, Vol. 43 (4), pp. 843-882.

Hackbarth, D., 2009, Determinants of Corporate Borrowing: A Behavioral Perspective, Journal of Corporate Finance, Vol. 15 (4), pp. 389-411.

Hambrick, D. C., and G. D. S. Fukutomi, 1991, The Seasons of a CEO's Tenure, Academy of Management Review, Vol. 16 (4), pp. 719-742.

Hambrick, D. C., and S. Finkelstein, 1987, Managerial Discretion: A Bridge between Polar Views of Organizational Outcomes, In B. Staw \& L. Cummings (Eds.), Research in Organizational Behavior, Vol. 9, pp. 369-406.

Hayward, M. L. A., and D. C. Hambrick, 1997, Explaining the Premiums Paid for Large Acquisitions: Evidence of CEO Hubris, Administrative Science Quarterly, Vol. 42 (1), pp. $103-127$.

Heaton, J. B., 2002, Managerial Optimism and Corporate Finance, Financial Management, Vol. 31 (2), pp. 33-45.

Hill, A. D., D. A. Kern, and M. A. White, 2014, Are We Overconfident in Executive Overconfidence Research? An Examination of the Convergent and Content Validity of Extant Unobtrusive Measures, Journal of Business Research, Vol. 67 (7), pp. 1414-1420. 
한국증권학회지 제 48 권 5 호 (2019)

Hirshleifer, D., A. Low, and S. H. Teoh, 2012, Are Overconfident CEOs Better Innovators?, Journal of Finance, Vol. 67 (4), pp. 1457-1498.

Hribar, P., and H. Yang, 2016, CEO Overconfidence and Management Forecasting, Contemporary Accounting Research, Vol. 33 (1), pp. 204-227.

Hwang, H., H.-D. Kim, and T. Kim, The Blind Power: Power-Driven CEO Overconfidence and M\&A Decision Making, Conference on The Korean Finance Association, Working Paper, Rutgers University, 2018.

Jensen, M. C., 1986, Agency Costs of Free Cash Flows, Corporate Finance, and Takeovers, American Economic Review, Vol. 76 (2), pp. 323-329.

John, K., L. Litov, and B. Yeung, 2008, Corporate Governance and Risk-Taking, Journal of Finance, Vol. 63 (4), pp. 1679-1728.

Kang, J., J.-K. Kang, M. Kang, and J. Kim, Are Overconfident CEOs Good Managers in Times of High Economic Uncertainty?, Conference on Asia-Pacific Financial Markets, Working Paper, Nanyang Technological University, 2017.

Kang, Y. S., and C. P. Kook, 2012, The Effect of Independent Outside Directors on Firm Value, Asian Review of Financial Research, Vol. 25 (3), pp. 451-498.

Kim, B., 2016, Managerial Opportunism, Overconfidence and Stock Price Crash Risk, Asian Review of Financial Research, Vol. 29 (2), pp. 193-233.

Kim, B., and J. H. Hwang, 2016, Directors' and Officers' Liability Insurance and Corporate Risk-Taking, Korean Journal of Financial Studies, Vol. 45 (5), pp. 1167-1197.

Kim, C., 2006, Outside Directors and Firm Value in Korea, Asian Review of Financial Research, Vol. 19 (2), pp. 105-153.

Kim, S.-R.-N., and H. Y. Ryu, 2014, Managerial Overconfidence and Cost Stickiness, Korea Accounting Journal, Vol. 23 (6) pp. 309-345.

Kolasinski, A. C., and X. Li, 2013, Can Strong Boards and Trading in Their Own Firm's Stock Help CEOs Make Better Decisions? Evidence from Acquisitions by Overconfident CEOs, Journal of Financial and Quantitative Analysis, Vol. 48 (4), pp. 1173-1206.

Kook, C. P., and Y. S. Kang, 2010, Investor Protection, Growth Opportunity and Risk Taking, The Korean Journal of Financial Management, Vol. 27 (2), pp. 115-144.

Kroll, M. J., L. A. Toombs, and P. Wright, 2000, Napoleon's Tragic March Home from Moscow: Lessons in Hubris, Academy of Management Executive, Vol. 14 (1), pp. 117-128.

Lee, J. H., and H. S. Byun, 2016, Product Market Competition and Corporate Risk-Taking, Asian Review of Financial Research, Vol. 29 (1), pp. 1-36.

Li, J., and Y. Tang, 2010, CEO Hubris and Firm Risk Taking in China: The Moderating Role of Managerial Discretion, Academy of Management Journal, Vol. 53 (1), pp. 45-68. 
Effects of Managerial Overconfidence on the Relationship between Corporate Risk-Taking and Firm Value

Malmendier, U., and G. Tate, 2005, CEO Overconfidence and Corporate Investment, Journal of Finance, Vol. 60 (6), pp. 2661-700.

Malmendier, U., and G. Tate, 2008, Who Makes Acquisitions? CEO Overconfidence and the Market's Reaction, Journal of Financial Economics, Vol. 89 (1), pp. 20-43.

Malmendier, U., G. Tate, and J. Yan, 2011, Overconfidence and Early-Life Experiences: The Effect of Managerial Traits on Corporate Financial Policies, Journal of Finance, Vol. 66 (5), pp. 1687-1733.

Miller, D. T., and M. Ross, 1975, Self-Serving Biases in the Attribution of Causality: Fact or Fiction?, Psychological Bulletin, Vol. 82 (2), pp. 213-225.

Park, D., and J. Hahn, 2017, The Business Cycle, Investor Sentiment, and Economic Policy Uncertainty: Their Impact on Corporate Investment, Employment, and Financing in the Presence of Costly External Finance, Journal of Money and Finance, Vol. 31 (1), pp. 1-38.

Park, J. H., Y. D. Sung, and C. S. Kim, 2013, The CEO Hubris and Firm Performance: The Moderating Role of Board Independence and Chaebol Affiliation, Korean Management Review, Vol. 42 (3), pp. 673-697.

Park, S. H., and K. H. Yon, 2009, The Effect of Corporate Governance on the Level of a Firm's Cash Holdings, Asian Review of Financial Research, Vol. 22 (2), pp. 1-36.

Rhodes, S. R., 1983, Age-Related Differences in Work Attitudes and Behavior: A Review and Conceptual Analysis, Psychological Bulletin, Vol. 93 (2), pp. 328-367.

Ryu, H. Y., and S.-R.-N. Kim, 2015, Managerial Overconfidence and Accounting Conservatism, Korea Accounting Review, Vol. 40 (6), pp. 41-80.

Schrand, C. M., and S. L. C. Zechman, 2012, Executive Overconfidence and the Slippery Slope to Financial Misreporting, Journal of Accounting Economics, Vol. 53, pp. 311-329.

Serfling, M. A., 2014, CEO Age and the Riskiness of Corporate Policies, Journal of Corporate Finance, Vol. 25, pp. 251-273.

Shleifer, A., and R. W. Vishny, 1989, Management Entrenchment : the Case of Manager Specific Investments, Journal of Financial Economics, Vol. 25 (1), 123-139.

So, K., J. Choi, and J. S. Park, 2014, What Makes Hubris?: Test of Its Determinants, Journal of CEO and Management Studies, Vol. 17 (1), pp. 145-165

Tang, Y., J. Li, and Y. Liu, 2016, Does Founder CEO Status Affect Firm Risk Taking?, Journal of Leadership and Organizational Studies, Vol. 23 (3), pp. 322-334.

Taylor, R. N., 1975, Age and Experience as Determinants of Managerial Information Processing, The Academy of Management Journal, Vol. 18 (1), pp. 74-81.

Yim, S., 2013, The Acquisitiveness of Youth: CEO Age and Acquisition Behaviour, Journal of Financial Economics, Vol. 108 (1), pp. 250-273. 